\title{
Energy Emergency Planning Guide: Winter 1977-78
}

DOE/ERA-0031

Interagency Task Force

for Winter Energy

Emergency Planning

November, 1977

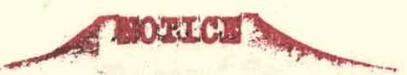

PORTIONS OF THIS REPORT ARE ILJEGIBLE It has been reproduced f rom the best available copy to permit the broadestpossible availability. 


\section{DISCLAIMER}

This report was prepared as an account of work sponsored by an agency of the United States Government. Neither the United States Government nor any agency Thereof, nor any of their employees, makes any warranty, express or implied, or assumes any legal liability or responsibility for the accuracy, completeness, or usefulness of any information, apparatus, product, or process disclosed, or represents that its use would not infringe privately owned rights. Reference herein to any specific commercial product, process, or service by trade name, trademark, manufacturer, or otherwise does not necessarily constitute or imply its endorsement, recommendation, or favoring by the United States Government or any agency thereof. The views and opinions of authors expressed herein do not necessarily state or reflect those of the United States Government or any agency thereof. 


\section{DISCLAIMER}

Portions of this document may be illegible in electronic image products. Images are produced from the best available original document. 


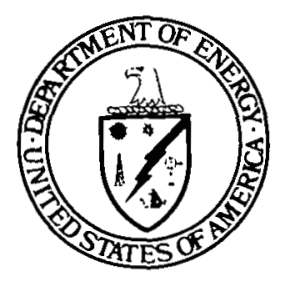

\title{
Energy Emergency Planning Guide: Winter 1977-78
}

DOE/ERA-0031

\author{
Interagency Task Force \\ for Winter Energy \\ Emergency Planning
}

November, 1977

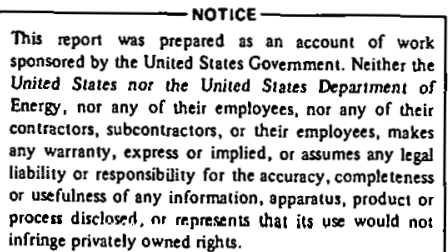


Last winter's energy shortages demonstrated once more the state and national responsibilities to plan for energy emergencies with regard to all forms of energy. Dwindling supplies, limited storage capacity and deliverability bottlenecks are gradually increasing the risk of energy supply emergencies, particularly during cold weather.

The energy industries have primary responsibility to act prudently so as to avoid crises and mitigate adverse impacts. Government actions can reinforce industry efforts to cope with emergencies and, if necessary, ensure that energy industries act in the public interest. Government can also offer some relief from injuries suffered by the consuming public, but there are limits to the capacity of government to control or compensate for adverse effects of shortages.

The Energy Emergency Planning Guide for this winter:

- Identifies and evaluates actions available to deal with winter energy problems;

- Provides an advance indication to the public of those actions considered most likely to be taken by the federal government; and

- Provides state and local governments with recommended actions they can take to deal with energy emergencies.

In the Department of Energy's continuing emergency planning program, the Planning Guide for this winter is also a preliminary draft for subsequent plans. We, therefore, seek comments for further improvements.

Many of the steps outlined here are already being implemented, while others depend upon congressional action (e.g., extension of the Emergency Natural Gas Act, proposed in the National Energy Act; and the Special Crisis Intervention Program). As the winter approaches, we will continue to work with other units of government and with the private sector to raise our national level of preparedness.

The Winter Energy Emergency Plans Task Force had help from the Emergency Preparedness Subcommittee of the National Governors' Association, members of the National Conference of State Legislatures, the National Association of Counties, the National Conference of Mayors/League of Cities, and numerous other people in government and the private sector. We acknowledge with gratitude their assistance, and anticipate a continued joint effort in preparing for
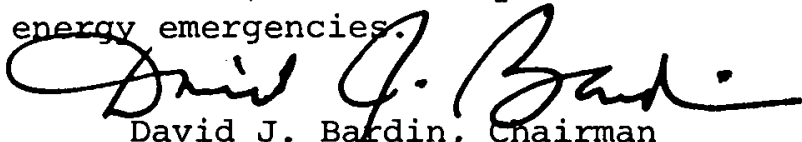

David J. Bacdin, Enairman Interagency Task Force For Winter Energy Emergency Plans 
EXECUTIVE SUMMARY ................... iv

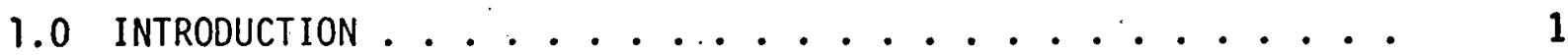

1.1 Purpose of Planning Guide . . . . . . . . . . . 1

1.2 Synopsis of Contents. . . . . . . . .... 1

1.3.1 Potential Causes of an Energy Emergency. . . . . 3

1.3.2 Specific Issues. . . . . . . . . . . . 5

1.3 .3 Regional Impacts . . . . . . . . . . . 8

2.0 CRisis management. ............................. 10

2.1 Implementation Guidelines . . . . . . . . . 10

2.1.1 Basic Principles ................ 10

2.1.2 General Guidelines .. . . . . . . . . . . . 11

2.1.3 Implementation Guidelines for Natural Gas

2.1.4 Implementation Guidelines for Petroleum

Shortages. . . . . . . . . . 20

2.1.5 Implementation Guidelines for Electricity and Coal Shortages.............

2.1.6 Implementation Guidelines for Propane Shortages. .

2.1.7 Impact Assistance Measures ..........

2.2 Legal Authorities . . . . . . . . . . . 31

2.2.1 Currently Authorized Measures. . . . . . . . . 31

2.2.2 Measures requiring legislation ........ 33

2.2.3 Current status............ 34

2.3 Winter Energy Data Bulletin ............ 35

2.4 Energy Emergency Center . . . . . . . . . . 40

3.0 ENERGY EMERGENCY MeASURES . . . . . . . . . . . . . 41

3.1 Summary. . . . . . . . . . . . . . 41

3.2 Natural Gas Measures . . . . . . . . . . . 41

3.2.1 Maximize Storage Levels ............ 45

3.2.2 Encourage Increased Imports ........... 49

3.2.3 Implement. Special Rule for Domestic Ethane-
Propane Mixtures as Supplemental Natural Gas. . . . 49

3.2.4 State-Run Exchange Program. ......... 51

3.2.5 State-Run Intrastate Redirection. ........ 54 
TABLE OF CONTENTS (Continued)

$\underline{\text { Page }}$

3.2.6 Accelerate Federal Lease Production....... 56

3.2.7 Reallocate Federal Royalty Gas. . . . . . . . 58

3.2 .8 Permit Temporary Sales Arrangements . . . . . 60

3.2.9 Allocate Under Section 4 of ENGA. . . . . . . . 61

3.2.10 Ban Use of Natural Gas as a Boiler Fue1. . . . . 73

3.3 Electricity and Fuel Switching Actions ......... 86

3.3.1 Power Pool Fuel Sharing Agreements. . . . . . . . 886

3.3.2 Reduce Uranium Enrichment Load. . . . . . . . . 88

3.3.3 Mandate Electrical Energy Transfer, Interchange, . . 92

3.3.4 Modify Coal Conversion Orders . . . . . . . . . . 98

3.4 Propane. . . . . . . . . . . . . 100

3.4.1 Clarify DOE Position un Propante Inupurts . . . . . 100

3.4.2 Enforce Restrictions on Use of Propane as

Alternate Fuel. . . . . . . . . . 103

3.4.3 Establish Emergency Methnd of Propane Aliocation. 108

3.5 Petroleum. ................ 110

3.5.1 Implement Middle Distillate State Set-Aside

Program ............... . 111

3.5.2 Order Refinery Yield Adjustments. ....... . 117

3.5.3 Grant Entitlements for Imported Middle Distillales. 110

3.5.4 Impose Allocation Controls. . . . . . . . 123

3.5.5 Drawdown Strategic Reserves . . . . . . . . 125

3.6 Transportation ...................... 121

3.6.1 Suspend Driver Hours of Service Restrictions . . . 127

3.6.2 Defer Vehicle Inspection Requirements...... 129

3.6.3 Waive Jones Act. . . . . . . . . . . . 130

3.6.4 Grant Emergency Temporary Authority to. Transport.

Critical Commodities......... 132

3.6.5 Direct Priority in Movenlerit. . . . . . . . . . 136

3.6.6 Prohibit Trains from Entering Impassable Areas . 137

3.6.7 Direct Movement of Privately Owned Railcars. . . 138

3.6.8 Implement Priority and Allocation Authority. . . 139

3.7 Demand Restraint Measures .............. 140

3.8 Materials Allocation. ............. 142 
TABLE OF CONTENTS (Continued)

Page

3.9 Assistance Programs . . . . . . . . . . . . . 144

3.9.1 Distribute Energy Emergency Handbook . . . . . . . 145

3.9.2 State and Local Voluntary Assistance Programs. . . 147

3.9.3 Permit Emergency Supply and Transfer from Federal Stocks .................. 148

3.9.4 Assist Low-Income People in Payment of Fuel Bills. 150

3.9.5 Implement Special Energy Assistance for the Elderly. . . . . . . . . . 153

3.9.6 CSA Crisis Intervention. . . . . . . . . 155

3.9.7 Issue Emergency Food Stamps to Supplement Needs During an Energy Emergency . . . . . . . . . 159

3.9.8 Expedite Unemployment Compensation Claims Resulting from Layoffs due to Energy Shortages . . . 161

3.9.9 Set Up Short-Term Public Service Employment. . . . 162

3.9.10 Encourage Moratoria on Utility Service Cut-Offs and Non-Delivery of Heating Fuels due to Lack of Cash. . . . . . . . . . . . . . 164

3.9.11 Provide Smal1 Business Assistance for Energy Related Emergencies . . . . . . . 166

APPENDICES (Separate Volume)

1. Outline of Energy Emergency Handbook

2. Measures Not in the Guide

3. Agency Responsibility Chart

4. Presidential Authorities Sumary

5. State Energy Emergency Legislation

6. Information Systems

7. Energy Emergency Center

8. Cost of Measures

9. List of Agencies Which Provided Written

Comments on the Draft Planning Guide 
THIS PAGE

\section{WAS INTENTIONALLY}

\section{LEFT BLANK}




\section{EXECUTIVE SUMMARY}

- This Energy Emergency Planning Guide for Winter, 1977-78 has been prepared in order to:

- Identify and evaluate actions available to deal with energy emergencies this winter,

- Provide an advance indication to the public of those actions considered most likely to be taken by the government, and

- Provide industry, State and local governments with suggestions about actions which they can take to deal with energy emergencies this winter.

- The Guide contains specifications for over 50 standby programs and procedures, recommended implementation guidelines for using these programs keyed to a pre-emergency phase and three phases of shortfalls, and a design for an Energy Emergency Center.

- The Guide has been developed by an interagency task force established by Secretary of Energy James R. Schlesinger, on July 8, 1977. The task force Chairman is David J. Bardin, Administrator of the Economic Regulatory Administration. Other members include officials of the Federal Energy Regulatory Commission (FERC) in the Department of Energy, and the Department of Interior, Department of Commerce, Department of Transportation, Department of Agriculture, Environmental Protection Agency, and Federal Preparedness Agency. Many other agencies also have been consulted.

- In developing this Guide, the Task Force has consulted with local officials through the Emergency Preparedness Subcommittee of the National Governors' Association, members of the National Conference of State Legislatures, the National Association of Counties, and the National Conference of Mayors/League of Cities. Industry and consumer groups have been consulted through the DOE Advisory Committees.

- Because of the difficulty of reliably predicting the nature, severity, and duration of potential energy emergencies this winter, the Guide considers conditions up to and including extreme cases.

- A premise of the Guide is that the energy industries have the primary responsibility to meet supply obligations, but government actions are needed either to facilitate and reinforce private responsibilities or to step in when industry cannot cope with an emergency. 
- Within this context, flexible implementation guidelines are proposed for natural gas, petroleum, electricity/coal, and propane shortages, keyed to four phases:

- Phase 1: Pre-emergency planning -- now in process.

- Phase 2: Mild - curtailments of natural gas confined to firm industrial requirements for boiler fuel use or interruptible requirements with alternate fuel capabilities; or localized shortages, nowhere exceeding $10 \%$ of projected normal demand, for any other fuel type.

- Phase 3: Moderate - widespread curtailments for natural gas for industrial requirements, only spot curtailments of large commercial (50,000 cubtc feet or more on a peak day) uses; or shortages exceeding 10\% of projuilent normal demand for drly other tuel type.

- Phase 4: Severe - widespread curtailments of natural gas for large commercial requirements with the threat of curtailments for residential and small commercial (less than 50,000 cubic feet on a peak day) uses; or shortages exceeding $10 \%$ of projected normal demand on an aggregate national basis for any other fuel type. I

- The charts on the following pages outline the proposed fuel-specific measures according to these phases. The charts are intended to indicate the maximum measures to deal with shortages; it may not be necessary or appropriate to use all of the measures listed for a particular phase. The measures indicated for state action are-intended as recommendations for state implementation. A composite chart of Federal measures is followed by the special charts for natural gas, petroleum, and electricity/coal which include federal, state, and industry emergency measures.

- Because of the potential for fuel substitution, the measures associated with a particular phase may be used before that phase is reached for that fuel to avoid shortages in other fuels.

I/ On this basts, last winter's natural gas shortage was a Phase 4 natural gas emergency. The 1973-74 oil embargo was a Phase 4 petroleum emergency affecting 14\% of petroleum consumption. The western drought of 1977, which reduced hydroelectricity supply in California and the Pacific Northwest, was a Phase 2 electric emergency. 


\begin{tabular}{|c|c|c|c|c|}
\hline $\begin{array}{l}\text { ENERG } \\
\text { YYP }\end{array}$ & NATURAL GAS & PETROLEUM & ELECTRICITY/COAL & PROPANE \\
\hline $\begin{array}{l}\text { PHASE I } \\
\text { PRIOR TO } \\
\text { SHORTAGE }\end{array}$ & $\begin{array}{l}\text { - Maximize Storage Levels } \\
\text { - Facilitate increased } \\
\text { Imports of Natural Gas } \\
\text { when they become needed } \\
\text { - Encourage Oevelopment of } \\
\text { State Operated Fuel Ex- } \\
\text { change Programs } \\
\text { - Issue Special Rule for } \\
\text { Ethane-Propane Mixture }\end{array}$ & $\begin{array}{l}\text { - Establish a Middle Dis- } \\
\text { tillate State Set-Aside } \\
\text { Program }\end{array}$ & $\begin{array}{l}\text { - Provide Assistance to } \\
\text { Electric utflities in } \\
\text { Developing Contingency } \\
\text { Plans and Agreements }\end{array}$ & $\begin{array}{l}\text { - Clarify Position on In- } \\
\text { creased Imports for } \\
\text { Winter } \\
\text { - Fully Implement Exist- } \\
\text { ing Restrictions on Use } \\
\text { of Propane as Alternate } \\
\text { Fuel for "Less Essential } \\
\text { Uses" } \\
\text { - Issue on standby basis } \\
\text { special rule for emer- } \\
\text { gency allocation }\end{array}$ \\
\hline \multicolumn{5}{|c|}{$\begin{array}{l}\text { IMPLEMENT APPLICABLE MEASURES DESIGNATED FOR PHASE I } \\
\text { IMPLEMENT MODEST FEDERAL PUBLIC INFORMATION PROGRAM }\end{array}$} \\
\hline $\begin{array}{l}\text { PHASE II } \\
\text { MILD } \\
\text { SHORTAGE }\end{array}$ & $\begin{array}{l}\text { - Activate Demand } \\
\text { Restraint Program for } \\
\text { Federal Facilities } \\
\text { - Accelerate Production } \\
\text { from Federal. Lease } \\
\text { - Authorize Emergency } \\
\text { Sales Arrangements } \\
\text { - Monitor Natural Gas } \\
\text { Curtailment Programs }\end{array}$ & $\begin{array}{l}\text { - Activate Demand } \\
\text { Restraint Frogram for } \\
\text { Federal Facilities } \\
\text { - Grant Authority to } \\
\text { Move Critical } \\
\text { Commodities* } \\
\text { - Prohibit Trains from } \\
\text { Entering Impassable } \\
\text { Areas* } \\
\text { - Direct Priority Move- } \\
\text { ment of Essential } \\
\text { Commodities* } \\
\text { * Severe local shortages } \\
\text { which are not adequately } \\
\text { addressed by voluntary } \\
\text { action. }\end{array}$ & $\begin{array}{l}\text { - Activate Demand } \\
\text { Restraint Program for } \\
\text { Federal Facilities } \\
\text { - Encourage Power } \\
\text { Wheeling and Similar } \\
\text { Transmissions Wher- } \\
\text { ever Local Shortages } \\
\text { are not Being Ade- } \\
\text { quately Addressed }\end{array}$ & $\begin{array}{l}\text { - Issue Temporary } \\
\text { Authority to Move } \\
\text { Critical Commodities* } \\
\text { - Oirect Railroads to } \\
\text { Give Priority to } \\
\text { Movement of Fuel and } \\
\text { Other Essential } \\
\text { Commodities* } \\
\\
\text { *For severe local } \\
\text { shortages which are not } \\
\text { adequately addressed by } \\
\text { voluntary action }\end{array}$ \\
\hline & \multicolumn{4}{|c|}{$\begin{array}{l}\text { IMPLEMENT APPL ICAÖLE MEASURES DESIGNATEO FOR PHASE II } \\
\text { IHPLEMENT ENHANCED FEDERAL PUBLIC INFORMATION PROGRAM }\end{array}$} \\
\hline $\begin{array}{l}\text { PHASE III } \\
\text { MOOERATE } \\
\text { SHORTAGE }\end{array}$ & $\begin{array}{l}\text { - Pre-empt Reserve Gas in } \\
\text { Ocs } \\
\text { - Reallocate Royalty Gas } \\
\text { from Federal Lanćs } \\
\text { - Prohibit Use of Natural } \\
\text { Gas as a Boiler Fuel (as } \\
\text { Practical) } \\
\text { - Ban Outdoor Gas Lamps }\end{array}$ & $\begin{array}{l}\text { - Implement Product } \\
\text { Entitlement Programs } \\
\text { - Suspend Oriver Hours of } \\
\text { Service Requirements } \\
\text { - Defer Vehicle Regis- } \\
\text { stration Requirements }\end{array}$ & $\begin{array}{l}\text { - Load Shedding at } \\
\text { Gaseous Diffusion } \\
\text { Plants } \\
\text { - Temporary Modification } \\
\text { of Coal Conversion } \\
\text { Orders }\end{array}$ & $\begin{array}{l}\text { - Implement Procedure } \\
\text { for Emergency Alloca- } \\
\text { tion of Propane }\end{array}$ \\
\hline \multicolumn{5}{|c|}{$\begin{array}{l}\text { IMPLEMENT APPLICABLE MEASURES DESIGIATED FOR PHASE III } \\
\text { IMPLEMLNT MNJOR FEDERAL PUBLIS. INFORMATION PROGRAM }\end{array}$} \\
\hline $\begin{array}{l}\text { PHASE IV } \\
\text { SEVERE } \\
\text { SHORTAGE }\end{array}$ & $\begin{array}{l}\text { - Estabish Mandatory } \\
\text { Thermostat Levels for } \\
\text { Commercial. Buildings } \\
\text { - Activate Emergency } \\
\text { Measures Under the } \\
\text { Defense Production Act } \\
\text { - Eliocate Mdlurd Gas to } \\
\text { Ensure Health, Safety } \\
\text { and Protection of } \\
\text { Property }\end{array}$ & $\begin{array}{l}\text { - Imposa Revised Alloca- } \\
\text { tion Program for } \\
\text { Petroleum Products } \\
\text { Which Have Been } \\
\text { Decontralled } \\
\text { - Orawdown Stratecic } \\
\text { Reserves } \\
\text { - Establish Mandatory } \\
\text { Refinary Yield Frogram } \\
\text { - Mandate Thermustal } \\
\text { Levels fur Commerical } \\
\text { Buildinas } \\
\text { - Obtain Emernency Trans- } \\
\text { portation Priority and } \\
\text { Allocation Authority } \\
\text { - Obta in ICC Authority } \\
\text { Over Privately Owned } \\
\text { Railcars } \\
\text { - Waive the Jones Act } \\
\text { as neccssary }\end{array}$ & $\begin{array}{l}\text { - Mandate Electricity } \\
\text { Transmission Between } \\
\text { Regions } \\
\text { - Tamporary Suspension of } \\
\text { Clean Air Implementa- } \\
\text { tion. }\end{array}$ & $\begin{array}{l}\text { - Expand ICC Standby } \\
\text { Authority to Include } \\
\text { Private Railcars } \\
\text { - Waive the Jones Act } \\
\text { as necessary }\end{array}$ \\
\hline
\end{tabular}




\begin{tabular}{|c|c|c|}
\hline \multirow{3}{*}{$\begin{array}{l}\text { PHASE } 1 \\
\text { PRIOR TO } \\
\text { SHORTAGE }\end{array}$} & $\begin{array}{c}\text { STATE } \\
\text { ACTIONS }\end{array}$ & $\begin{array}{l}\text { Implement public information program. } \\
\text { Plan fuel exchange programs, demand restraint measures, and intrastate } \\
\text { allocation of natural gas; and secure necessary legal authority. } \\
\text { plan management of localized shortages, and coordination with the federal } \\
\text { government and private industry. }\end{array}$ \\
\hline & $\begin{array}{l}\text { FEDERAL } \\
\text { ACTIONS }\end{array}$ & $\begin{array}{l}\text { Maximize storaqe levels. } \\
\text { Increased imports of natural gas } \\
\text { Issue special rule for ethane-propane mixture. } \\
\text { Encourage developnitent of state operated fuel exchange programs: } \\
\text { Prepare handbook for federal assistance during energy emergencies. } \\
\text { Oraft legislation, regulations, executive orders, procedures, etc.; to } \\
\text { support measures, which inay be implemented during Phases II, III, or IV. }\end{array}$ \\
\hline & $\begin{array}{l}\text { ENERGY } \\
\text { EMERGENCY } \\
\text { CENTER AND } \\
\text { INFORMATION } \\
\text { SYSTEMS }\end{array}$ & $\begin{array}{l}\text { Prepare the design of the Energy Emergency Center (EEC) and secure } \\
\text { facilities and equipment. } \\
\text { Implement new or modified information systems to effectively monitor } \\
\text { market activity and to identify aggregate and/or local shortages: } \\
\text { increase reporting frequency of natural gas storage systems; and review } \\
\text { curtailment plans. } \\
\text { Plan special data collection procedures to be implemented when natural } \\
\text { gas shortages occur. }\end{array}$ \\
\hline \multirow{3}{*}{$\begin{array}{l}\text { PHASE II } \\
\text { MILD } \\
\text { SHORTAGE }\end{array}$} & $\begin{array}{c}\text { STATE } \\
\text { ACTIONS }\end{array}$ & $\begin{array}{l}\text { Activate fuel exchange plans (where appropriate). } \\
\text { Implement voluntary demand restraint measures (e.g., lower temperatures } \\
\text { for businesses and res1dences). } \\
\text { Incrcase scope and intens lty of public information program. } \\
\text { Redirect intrastate supplies among distributors. }\end{array}$ \\
\hline & $\begin{array}{l}\text { FEDERAL } \\
\text { ACTIONS }\end{array}$ & $\begin{array}{l}\text { Implement all Phase I measures (except maximization of storage lovole). } \\
\text { Implenternt demand restraint program for federal facilities. } \\
\text { Accelerate production from federal leases:" } \\
\text { Authorize emergency sales arrangements. }\end{array}$ \\
\hline & $\begin{array}{l}\text { ENERGY } \\
\text { EMERGENCY } \\
\text { CENTER AND } \\
\text { INFORMATION } \\
\text { SYSTEMS }\end{array}$ & $\begin{array}{l}\text { Implement EEC internal and external communications functions. } \\
\text { Implement supplemental data collection mechanisms such as telephone } \\
\text { surveys of distributors on an exception bas is (primarily to address } \\
\text { state and/or regional shortages). } \\
\text { Increase frequency of forecasts regarding national and local market } \\
\text { conditions. }\end{array}$ \\
\hline \multirow{3}{*}{$\begin{array}{l}\text { PHASE III } \\
\text { MODERATE } \\
\text { SHORTAGE }\end{array}$} & $\begin{array}{c}\text { STATE } \\
\text { ACTIONS }\end{array}$ & $\begin{array}{l}\text { Implement all measures designated for Phase II. } \\
\text { Implement severe demand restraint measures. } \\
\text { Implomont intensive public Information programs. }\end{array}$ \\
\hline & $\begin{array}{l}\text { FEDERAL } \\
\text { AC'I IONS }\end{array}$ & $\begin{array}{l}\text { Implement all measures des } 1 \text { gnated for Phase } I 1 \text {. } \\
\text { Allocate natural gas to ensure health, safety. and protection of property. } \\
\text { Pre-empt reserve gas in ocs. } \\
\text { Reallocate royalty gas from federal lands. } \\
\text { Prohibit use of natural gas as boiler fuei (as practical). } \\
\text { Bonl uutduor gas lamps. }\end{array}$ \\
\hline & $\begin{array}{l}\text { ENERGY } \\
\text { EMERGENCY } \\
\text { CENTER AND } \\
\text { INFORMATION } \\
\text { SYSTEMS }\end{array}$ & $\begin{array}{l}\text { Implement all EEC functions including internal and external communica- } \\
\text { tions, state and local government liaison, interagency coordination, } \\
\text { and integration of contingency measures. } \\
\text { Implement all supplenientary data cnllertion efforts including telephore } \\
\text { surveys of distributors and/or large end-users; weekly reporting of } \\
\text { underground storage; and/or systematic monitoring of curtailments. } \\
\text { Increase froquency of natural and regional forecasts of supply and } \\
\text { demand for natural gas.. }\end{array}$ \\
\hline \multirow{3}{*}{$\begin{array}{l}\text { PHASE IV } \\
\text { SEVERE } \\
\text { SHORTAGE }\end{array}$} & $\begin{array}{l}\text { STATE } \\
\text { ACTIUNS }\end{array}$ & Implement measures designated for Phase III. \\
\hline & $\begin{array}{l}\text { FEOERAL } \\
\text { ACTIONS }\end{array}$ & $\begin{array}{l}\text { Implement all Federai measures designated for Phase III. } \\
\text { Establish mandatory thermostat levels. for commerciall buildings. } \\
\text { Activate emergency measures under the Defense Production Act. }\end{array}$ \\
\hline & $\begin{array}{l}\text { FEDERAL } \\
\text { COORDINATION } \\
\text { CENTER AND } \\
\text { INFORMATION } \\
\text { SYSTEMS }\end{array}$ & $\begin{array}{l}\text { Take actions designated for phase III except scope and magnitude of } \\
\text { supplemeitary data collection may be increased; and frequency of } \\
\text { forecasts will be increased. }\end{array}$ \\
\hline
\end{tabular}




\begin{tabular}{|c|c|c|}
\hline \multirow{3}{*}{$\begin{array}{l}\text { PHASE I } \\
\text { PRIOR TO } \\
\text { SHORTAGE }\end{array}$} & $\begin{array}{l}\text { STATE } \\
\text { ACTJOHS }\end{array}$ & 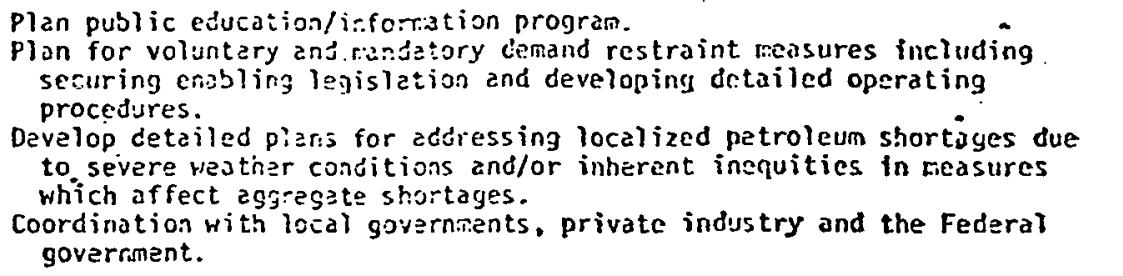 \\
\hline & $\begin{array}{l}\text { FEDERAL } \\
\text { ACTIONS }\end{array}$ & $\begin{array}{l}\text { Establish a midfle distillate state set-aside projran. } \\
\text { Prepare handbojk for Federel assistance during energy energensies. } \\
\text { Draft legislation, ragulations, executive orders, procedures. etc.s to } \\
\text { support measures Hhich may be implenented during Phases II, III and IV. }\end{array}$ \\
\hline & $\begin{array}{l}\text { EHERGY } \\
\text { EMEPGEHCY } \\
\text { CEHTER.AHO } \\
\text { INFORYATIOHI } \\
\text { SYSTEMS }\end{array}$ & 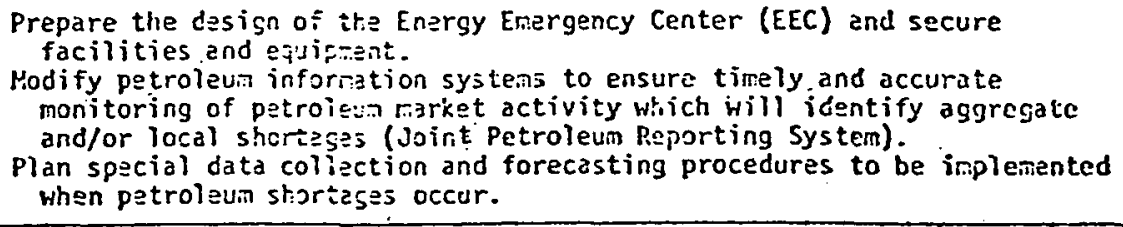 \\
\hline \multirow{3}{*}{$\begin{array}{l}\text { PHASE II } \\
\text { HILD } \\
\text { SHORTAGE }\end{array}$} & $\begin{array}{c}\text { STATE } \\
\text { ACTIONS }\end{array}$ & 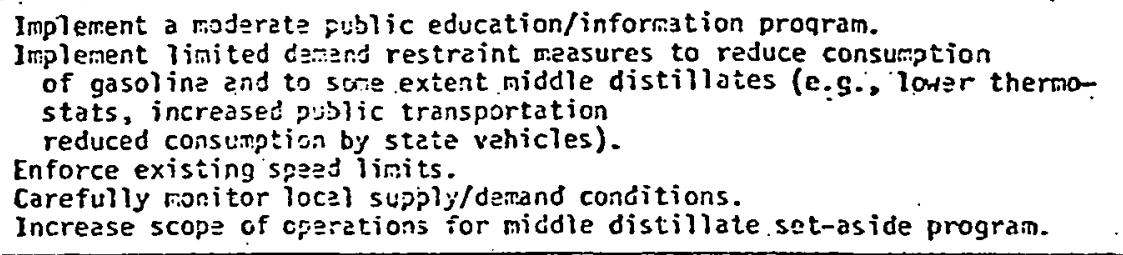 \\
\hline & $\begin{array}{l}\text { FEOERAL } \\
\text { A.CTIONS }\end{array}$ & 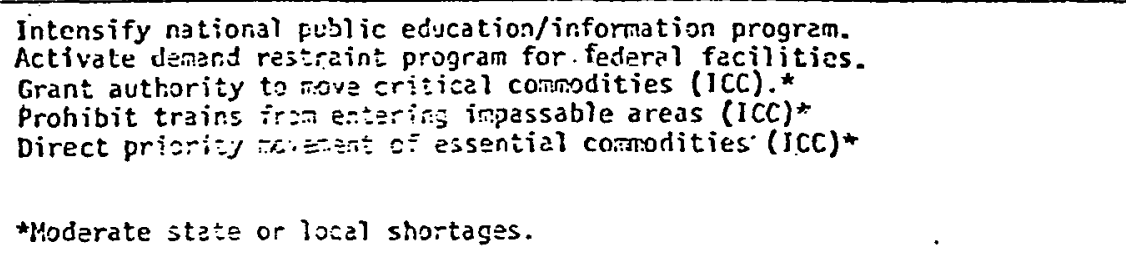 \\
\hline & $\begin{array}{l}\text { ENERCY } \\
\text { EMERGEMCY } \\
\text { CEIITER AHID } \\
\text { IHIFORMATION } \\
\text { SYSTEMS }\end{array}$ & 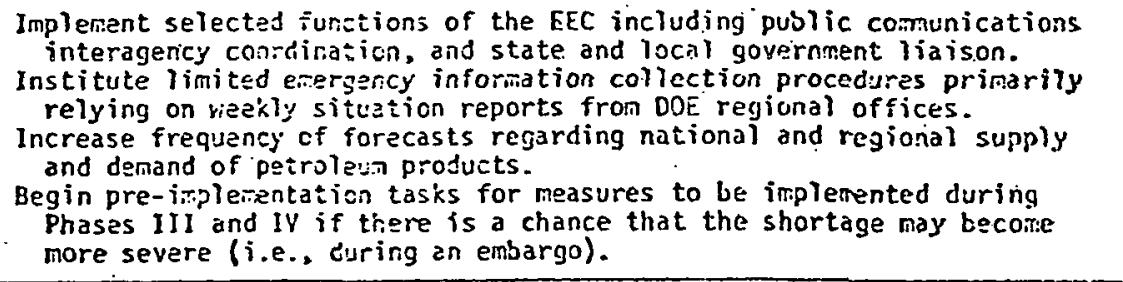 \\
\hline \multirow{3}{*}{$\begin{array}{l}\text { PHASE III } \\
\text { PODERATE } \\
\text { SHORTAGE }\end{array}$} & $\begin{array}{c}\text { STATE } \\
\text { ACTIOUIS }\end{array}$ & $\begin{array}{l}\text { Increase scope and intessity of public education/information program. } \\
\text { Implement mandatory derand restraint. measures which mey include reduced } \\
\text { business hours, reduced hours for gasoline retailers, odd-even gasoline } \\
\text { purchase program, reductions in comrercial lighting and heating. } \\
\text { restrictin3 access to certain areas to carposis, etc. }\end{array}$ \\
\hline & $\begin{array}{l}\text { FEOERAL } \\
\text { RCTIONS }\end{array}$ & $\begin{array}{l}\text { Implement all reasures which would be implemented during Phase II. } \\
\text { Implement projuct entitlesent progrims. } \\
\text { Suspend driver hours of service requirements. } \\
\text { Defer, vehicle inspection requibements. }\end{array}$ \\
\hline & $\begin{array}{l}\text { EHEPGY } \\
\text { EHERGEHCY } \\
\text { CEIITEP A:D } \\
\text { IHFOPJUTIOOI } \\
\text { SYSTEMS }\end{array}$ & 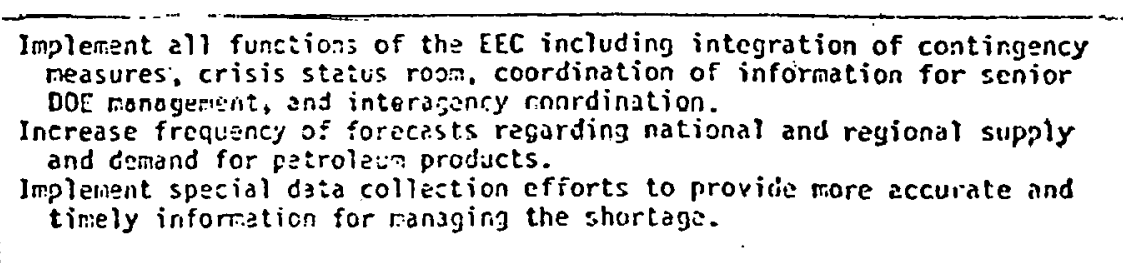 \\
\hline
\end{tabular}




\begin{tabular}{|c|c|c|}
\hline \multirow[b]{2}{*}{$\begin{array}{l}\text { PHASE IV } \\
\text { SEYERE } \\
\text { SH:RTRG }\end{array}$} & $\begin{array}{l}\text { STATE } \\
\text { ACTIONS }\end{array}$ & Implement measures designated for Phase III. \\
\hline & $\begin{array}{l}\text { FEDEPAL } \\
\text { ACTIOIIS }\end{array}$ & 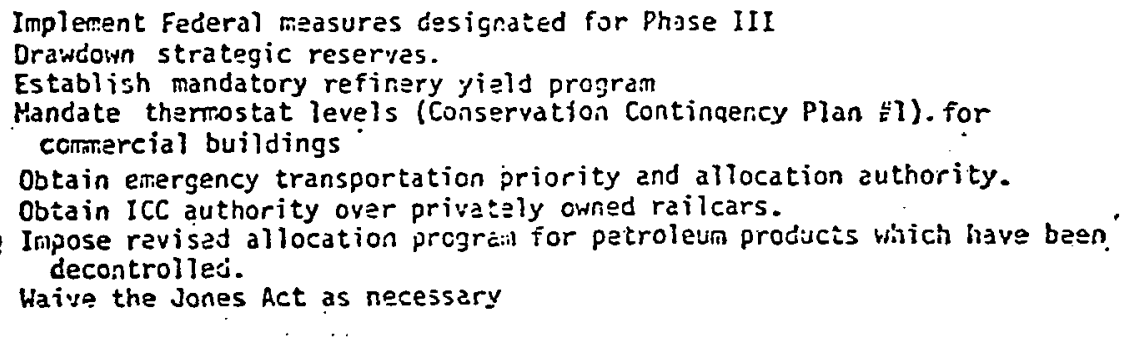 \\
\hline & $\begin{array}{l}\text { ENERGY } \\
\text { EMERGEHCY } \\
\text { CEHTER AND } \\
\text { IIIFOPYATION } \\
\text { SYSTEMS }\end{array}$ & $\begin{array}{l}\text { Implement actions designated for Phase III. } \\
\text { Implement and operate new iniormation systems }\end{array}$ \\
\hline
\end{tabular}


IMPLEMENTATION GUIOELINES FOR ELECTRICITY SHORTAGES

\begin{tabular}{|c|c|c|}
\hline \multirow{3}{*}{$\begin{array}{l}\text { PHASE } 1 \\
\text { PRIOR TO } \\
\text { SHORTAGE }\end{array}$} & $\begin{array}{l}\text { STATE AND } \\
\text { UTILITY } \\
\text { ACTIONS }\end{array}$ & $\begin{array}{l}\text { Encourage the development of agreements among intrastate and interstate } \\
\text { electricity producers and distributors for addressing an electricity } \\
\text { shortage. } \\
\text { ldentify iocalities most likely to be affected by electricity shortages } \\
\text { resulting from shortages of coal or petroleum; and prepare plans for } \\
\text { responding to the shortages. } \\
\text { obtain legislative authority for emergency measures }\end{array}$ \\
\hline & $\begin{array}{l}\text { FEDERAL } \\
\text { ACTIONS }\end{array}$ & $\begin{array}{l}\text { Provide assistance to electric utilities in developing } \\
\text { contingency plans. } \\
\text { Prepare a handbook for Federal assistance during emergencies. }\end{array}$ \\
\hline & $\begin{array}{l}\text { ENERGY } \\
\text { EMERGENCY } \\
\text { CENTER AND } \\
\text { INFORMATION } \\
\text { SYSTEMS }\end{array}$ & $\begin{array}{l}\text { Prepare the design of the Energy Emergency Center (EEC) and secure } \\
\text { facilities and equipment. } \\
\text { Develop the Electric Power Sufficiency Monitoring System to be used to } \\
\text { analyze supply and demand conditions and identify potential shortages } \\
\text { for specific utilities. }\end{array}$ \\
\hline \multirow{3}{*}{$\begin{array}{l}\text { PHASE II } \\
\text { MILD } \\
\text { SHORTAGE }\end{array}$} & $\begin{array}{l}\text { STATE AND } \\
\text { UTILITY } \\
\text { ACTIONS }\end{array}$ & $\begin{array}{l}\text { Activate agreements among utilities for responding to shortages (e.g., } \\
\text { PJM Coordinated Program for Reduction in Energy Use). } \\
\text { Implement moderate public education/information program. } \\
\text { Voluntary reductions in residential and commercial lighting. } \\
\text { Institute consumption goals for each class of consumer. }\end{array}$ \\
\hline & $\begin{array}{l}\text { FEDERAL } \\
\text { ACTIONS }\end{array}$ & $\begin{array}{l}\text { Implement demand restraint program for federal facilities. } \\
\text { Encourage power wheeling and similar transmissions wherever local } \\
\text {. shortages.are not being adequately addressed. }\end{array}$ \\
\hline & $\begin{array}{l}\text { ENERGY } \\
\text { EMERGENCY } \\
\text { CENTER AND } \\
\text { INFORMATION } \\
\text { STSTEMS }\end{array}$ & $\begin{array}{l}\text { Monitor utility fuel stocks which are in short supply, and perhaps in- } \\
\text { crease the frequency of supply and demand forecasts. } \\
\text { Implement se iective functions of the EEC if justified by the extent of } \\
\text { coal, petroleum, or natural gas shortage. }\end{array}$ \\
\hline \multirow{3}{*}{$\begin{array}{l}\text { PHASE III } \\
\text { MODERATE } \\
\text { SHORTAGE }\end{array}$} & $\begin{array}{l}\text { STATE AND } \\
\text { UTILITY } \\
\text { ACTIONS }\end{array}$ & $\begin{array}{l}\text { Implement mandatory demand restraint measures with respect to residential } \\
\text { and commercial heating and/or lighting. } \\
\text { Institute consumption reduction goals for each.class of consumer which } \\
\text { are higher than those in phase II. } \\
\text { Implement procedures to reduce loss of electricity due to maintenance } \\
\text { and operating procedures of utilities. } \\
\text { Reduce transmissions to selected large consumers (for extreme local } \\
\text { shortages only). }\end{array}$ \\
\hline & $\begin{array}{l}\text { FEDERAL } \\
\text { ACTIONS }\end{array}$ & $\begin{array}{l}\text { Load shedding at ERDA's gaseous diffusion plants. } \\
\text { Temporarily modify coal conversion orders. }\end{array}$ \\
\hline & $\begin{array}{l}\text { ENERGY } \\
\text { EMERGENCY } \\
\text { CENTER AND } \\
\text { INFORMATION } \\
\text { SYSTEMS } \\
\end{array}$ & Implement measures designated for Phase II. \\
\hline \multirow{3}{*}{$\begin{array}{l}\text { PHASE IV } \\
\text { SEVERE } \\
\text { SHORTAGE }\end{array}$} & $\begin{array}{l}\text { STATE AND } \\
\text { UTILITY } \\
\text { ACTIONS }\end{array}$ & $\begin{array}{l}\text { Implement measures designated for Phase III; however, reduction and/or } \\
\text { suspension of transmission to selected consumers would be relied on } \\
\text { to a greater extent. } \\
\text { Temporarily suspend clear air implementation plans }\end{array}$ \\
\hline & $\begin{array}{l}\text { FEDERAL } \\
\text { ACTIONS }\end{array}$ & $\begin{array}{l}\text { Implement all measures desiynated for Phase lII. } \\
\text { Mandate electricity transmission between regions. } \\
\text { Temporarily susoend clear air imnlementation nlans }\end{array}$ \\
\hline & $\begin{array}{l}\text { ENERGY } \\
\text { EMERGENCY } \\
\text { CENTER AND } \\
\text { INFORMATION } \\
\text { SYSTEMS. }\end{array}$ & $\begin{array}{l}\text { Implement all functions of the EEC and institute special data collection } \\
\text { and monitoring procedures to respond to local shortage of electricity } \\
\text { (e.g., altering the criteria for submission of FPC form } 247 \mathrm{~A} \text { or } 247 \mathrm{~B} \text {. }\end{array}$ \\
\hline
\end{tabular}




\section{THIS PAGE}

\section{WAS INTENTIONALLY \\ LEFT BLANK}

$x i \mathrm{i}$ 


\subsection{Introduction}

\subsection{Purpose of Planning Guide}

The Energy Emergency Planning Guide Winter, 1977-78 specifies standby procedures for handling energy emergencies this winter and the means for having them in place. The Planning Guide was developed by a Federal Interagency task force in coordination with State and local government officials and representatives of private industry and consumer groups.

The task force adopted the following basic assumptions and ground rules in developing the planning guide:

- Since it is impossible to predict with full accuracy the precise nature and magnitude of energy shortages that may occur this winter, the guide addresses preparations to the maximum extent possible for all conditions up to and including extreme cases. Potential problems addressed include regional and nationwide shortages of natural gas, propane, petroleum products, coal, and electricity as well as bottlenecks in the country's transportation and distribution network.

- The varied energy industries have the primary responsibility for meeting their utility and contractual commitments. Government action may be needed to facilitate or reinforce private responsibility or to step in when private industry cannot cope with an emergency.

- State and local authorities are best able to deal with mild energy shortages. Therfore, the guide provides that the Federal Government take special emergency actions only under serious emergency conditions, to remedy inequities among the states, to fill any voids caused by limitations on state power, and to deal with those areas where national management is essential. Of course, ongoing activities of federal agencies to monitor or prevent energy shortages will continue.

- While extensive opportunity for review and comment during preparation of these planning guidelines has been afforded to state and local governments, various industrial representatives, and consumer groups, the provisions of the Administrative Procedures Act ( 5 U.S.C. 551 et seq) and other applicable laws must still be satisfied. Thus, whenever a specific measure calls for promulgation of regulations or adjudicatory procedures, all provisions of law will be followed. 


\subsection{Synops is of Contents}

Guidelines for dealing with energy emergencies this winter are laid out in this document. The possible shortages which may arise are described in the following part of the Introduction.

Section 2 includes implementation guidelines expressed in terms of the phasing in of specific measures to deal with specific shortages, a summary of legal requirements, and a discussion of the Winter Energy Data Bulletins.

Section 3 contains details of the specific measures which have been or could be implemented to deal with local or nationwide shortages of natural gas, propane, petroleum, coal or electricity and for dealing with potential problems relating to the distribution of energy suppities and economic dislocations.

The abbreviations used in this Guide are as follows:

$\begin{array}{ll}\text { CSA } & \text { Community Services Administration } \\ \text { CEDE } & \text { Central Economic Dispatch Entities } \\ \text { CETA } & \text { Comprehensive Employment Training Act } \\ \text { DOC } & \text { Department of Commerce } \\ \text { DOE } & \text { Department of Energy } \\ \text { DOL } & \text { Department of Labor } \\ \text { DOT } & \text { Department of Transportation } \\ \text { DPA } & \text { Defense Production Act } \\ \text { EEC } & \text { Energy Emergency Center } \\ \text { EEI } & \text { Edison Electric Institute } \\ \text { EDS } & \text { Environmental Data Service } \\ \text { EPA } & \text { Environmental Protection Administration } \\ \text { ENGA } & \text { Emergency Natural Gas Act } \\ \text { EPAA } & \text { Emergency Petroleum Allocation Act } \\ \text { EPCA } & \text { Energy Policy and Conservation Act } \\ \text { ERA } & \text { Economic Regulatory Administration } \\ \text { ESECA } & \text { Energy Supply and Environmental Coordination Act } \\ \text { FFA } & \text { Federal Enelgy Administration } \\ \text { FERC } & \text { Federal Energy Regulatory Commission } \\ \text { FPC } & \text { Federal Power Commission } \\ \text { HEW } & \text { Department of Health, Education, and Welfare } \\ \text { ICC } & \text { Interstate Commerce Connission } \\ \text { JPRS } & \text { lnint Petrolcum Rcporting System } \\ \text { NEA } & \text { National Energy Act } \\ \text { NOAA } & \text { National Oceanic and Atmospheric Administration } \\ \text { NWS } & \text { National Weather Service } \\ \text { OCS } & \text { Outer Continental Shelf } \\ \text { OMB } & \text { Office of Management and Budget } \\ \text { OVEC } & \text { Ohio Valley Electric Corp. } \\ \text { PAD } & \text { Petroleum Administration for Defense } \\ \text { SBA } & \text { Smal Business Administration } \\ \text { TVA } & \text { Tennessee Valley Authority } \\ \text { WEEP } & \text { Winter Energy Emergency Plan } \\ & \end{array}$




\subsection{Possible Emergencies}

\subsubsection{Potential Causes of an Energy Emergency}

Some of the events which could occur to create an energy emergency during the winter of 1977-78 would be serious enough to cause a major crisis by themselves, while others have limited impact and probably would not cause a crisis unless they occurred in combination with other probelms affecting the same geographical region.

The most serious potential causes of an energy emergency in the coming winter are (1) severe, long-lasting, low temperatures, (2) a major coal work stoppage, and (3) an oil embargo. Other events which could contribute to an energy emergency are (4) natural disasters affecting energy production or distribution, such as droughts, fires, floods, storms, earthquakes, or heavy snows, and (5) work stoppages in energy- related industries other than coal.

In general, an energy problem exists whenever supplies fo fuels or electricity are inadequate to meet demand. However, it is useful to distinguish three ways in which an energy problem with any fuel or electricity can come about:

- Demand exceeds expected levels,

- Supplies (including stocks) are less than expected,

- Distribution systems are disrupted.

All of the events listed as potential causes of an energy emergency can be classified according to these three different kinds of energy crises. It is significant that many of the potential causes of an energy emergency could have on impact in more than one of the three ways just mentioned. For example, an oil embargo would reduce supplies of several fuels and simultaneously increase demand for alternate fuels. Severe cold temperatures would not only increase demand for fuels for ehating, but would also disrupt some fuel distribution systems as rivers froze over.

Exhibit 1.3.1 shows which fuels would be affected by different causes of an energy emergency and how these effects would be felt in terms of demand, supply, or distribution problems. 
Exhibit 1.3 .1

CAUSES OF AN ENERGY EMERGENCY

EVENT

FUELS AFFECTED

TYPE OF ENERGY IMPACT

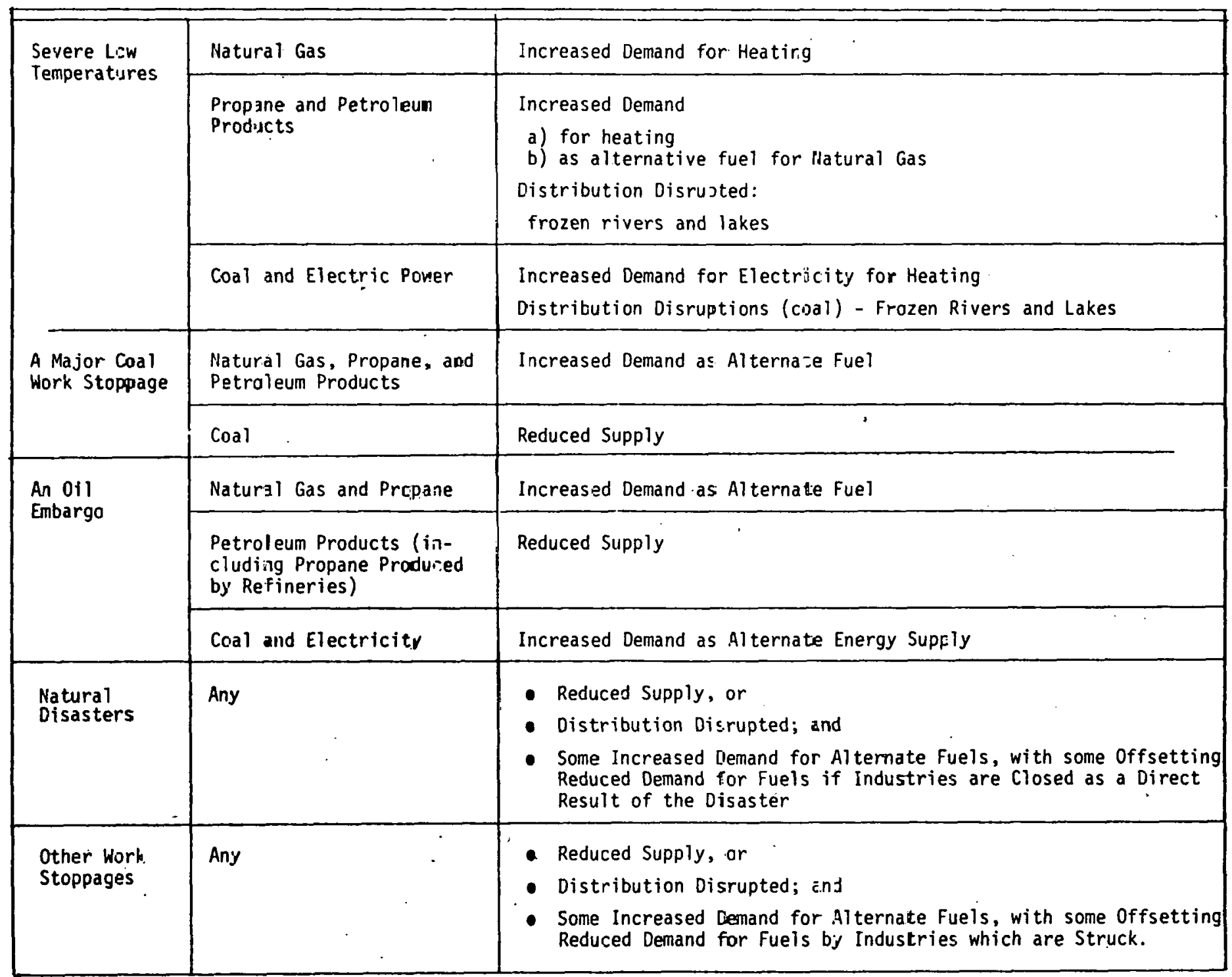


This analysis provides a useful first step in determining what kind of governmental measures are appropriate in relieving energy emergency hardships. For example, if supplies are adequate but distribution system bottlenecks are causing shortages in certain regions l/, then governmental measures to increase supplies would clearly not be appropriate.

\subsubsection{Specific Issues}

This section highlights supply, demand, distribution and weather issues relating to specific fuels for the coming winter of 1977-78. The estimates of supply and demand exclude the effect of actions contained in this plan which might be taken to mitigate shortages.

\section{Weather}

As of this writing, there is no reliable forecast for the winter of 1977-78. While some private forecasters have predicted colder than normal temperatures, the reliability of such predictions is not known. Last winter was $14 \%$ colder than normal on a national basis 2 / but it was considerably colder than that in certain areas.

\section{- Natural Gas}

Interstate pipeline companies estimated (as of Apri) 1977 ) that firm customer curtailments under normal winter conditions would be 1.66 Tcf this winter or $23 \%$ of firm requirements, as compared to 1.53 Tcf actual7y experienced last winter, an increase of $130 \mathrm{Bcf}$. (Source: FPC Form 16) When supplemental supplies available to intrastate pipelines and distributors are taken into account, total curtailment to end-users under normal winter conditions are estimated for this winter at $1.83 \mathrm{Tcf}$, or $18 \%$ of total requirements, down from 1.99 Tcf actually experienced last winter, a decrease of $15 \overline{\mathrm{Bcf}}$. Total gas deliveries are expected to be down 258 Bcf, principally due to reduced domestic production of natural gas and lesser accounting for emergency purchases. However, total requirements are expected to be down $413 \mathrm{Bcf}$ due principally to lesser space heating requirements under normal winter conditions and the effects of conservation measures alld permanent conversions to alternate fuels, despite increases in high priority customers on some systems. (Source: FEA/FPC survey of 1700 pipelines and distribution companies)

\footnotetext{
1/This was the case in last winter's heating oil shortages. Accordina to a report released by the Federal Energy Administration (FEA) of Product Allocations on August 4, 1977, "...shortfalls (in 1976-77) resulted not from a lack of total supply but rather from increased demand that exceeded delivery capacities of transportation systems." 2/Expressed in terms of degree days as compared to the 30-year average.
} 
Although total curtailments to end-users are projected down 151 Bcf, curtailments of firm end-use customers under normal weather conditions are down 144 BCf from that actually experienced last winter. of the 1.83 Tcf of total end-use curtailments, only 678 Bcf is to firm customers, while $1.15 \mathrm{Tcf}$ is to interruptible customers. Interruptible customers usually have alternate fuel capability.

The FERC held proceedings to acquire information from 29 major interstate pipelines on end-user curtailment impacts under normal and $10 \%$ colder than normal winter conditions. Twenty-three of the pipelines projected no significant adverse impacts this winter even if the winter is $10 \%$ colder than norma 1 . None reported any potential curtailment of priority one customers under colder than normal conditions, or any significant dislocations under normal weather conditions.

A follow-up proceeding was held to more closely study the potential impacts on the six pipelines that projected significant economic dislocations such as sustained plant shutdowns.

Based on this study of plpelines, no significant industrial dislocations are projected to occur under 10\% colder than normal conditions if emergency supplies are available. Adequate supplies do appear to be available according to a FERC survey of producers, pipelines, distributors, and refineries, who sold large volumes of emergency gas last year. These sources indiicated that $205 \mathrm{Bcf}$ could be available under normal weather conditions, and 183 Bcf under $10 \%$ colder than normal. Approximately 100 Bcf of emergency purchases were delivered and used in the interstate market last winter.

\section{- Propane}

Propane production during the coming winter is expected to come from natural gas processing plants (about 53\%), oil refining (about $30 \%$ ), and imports (about 17\%). Propane inventories on october 1 , 1977, were about 87 million barrels (compared to 96 million barrels last

year). Even under normal weather conditions, North Carolina and South Carolina are susceptible to propane shortages due to capacity limitations of the Dixie pipeline. Primary storage for propane in North Carolina is minimal. South Carolina will have the largest gas curtailment-related increase in propane demand and may have spot supply problems.

Unider 10\% colder than normal winter conditions, North Carolina, South Carolina, Tennessee, Kentucky, Ohio and Pennsylvania all are susceptible to propane shortages due to limited capacities of transportation systems. 
- Residual Fuel 0 il and Middle Distillate

At the national aggregate level, middle distillates and residual fuel oil supplies for the 1977-78 winter are projected to be adequate to cover the projected curtailments of natural gas for either a normal or $10 \%$ colder than normal winter. Propane supplies will also be adequate when aggregated at the national level. (Source: ERA Report on Alternate Fuels Availability, October 12)

Heavy fuel oil (residual) is the primary alternate fuel needed to replace curtailed gas volumes, while light fuel oil (middle distillates) is second in importance. As of September 30, 1977, crude 0il stock levels were up $17 \%$, primary stocks of heavy fuel oi 1 s were $2.4 \%$ higher, and inventories of light heating oils were $6 \%$ higher than on the same date last year.

There will be serious impacts in the event of an imports

$\backslash$ embargo. In the extreme case crude $0 i 1$ and product shortfalls of up to 3.3 million barrels per day could occur (based on January 1977 direct and indirect imports from the Arab members of OPEC).

In summary, absent an embargo, supply of residual fuel oil and middle distillate will be adequate for either a. cold or normal 1977-78 winter heating season. Therefore, no major supply problems are anticipated with these proudcts, although transportation-related shortages could occur. 


\section{- Coal and Electricity}

There are two significant threats to adequate coal supplies for the comming winter. Both are related to work stoppages. The first of these is the potential strike by the United Mine Workers of America (UMWA) against the Bituminous Coal Operators Association (BCOA) after the current three-year contract expires on December 6 , 1977. Some production has already been lost due to wildcat strikes. The second threat is a potential rail strike which would have a major impact since most coal is transported by rail.

Another problem which would affect coal during the coming winter is the possibility of extremely cold weather freezing rivers and lakes, blocking coal barge traffic, interfering with coal handling equipment, and freezing coal in railcars and stockpiles.

It is estimated that coal stocks at electric utilities will be over 130 million tons by early winter (approximately 90 days of supply). December 6, 1977, coal stocks for general industry and oven coke plants are estimated at 57 and 56 days of supply respectively.

While there is some potential demand for coal as an-alternate fuel during oil and natural gas shortages, such demands shuuld not be a significant factor unless a lengthy strike sharply reduces production and reduces coal stockpiles to much lower levels.

A reduction in hydroelectric power production may result from continuing droughts in various parts of the U.S. In states now heavily dependent on hydroelectric generation for their electric power. these droughts will require either llic use of fossil fuels in auxiliary generation equipment or the purchase of electric power through interconnections from other areas of the country. Either way, demands for fossil fuels (especially petroleum and coal) would increase, adding to shortages which might be experienced in these fuels during the coming winter.

\subsubsection{Regional Impacts}

The previous sections described possible energy emergency scenarios from a gerrerd, national perspective. Because of unique regional fuel dependencies and transportation systems, any energy emergency in the U.S. during the 1977-78 winter is likely to impact some regions far more than others. For instance, given an embargo, the resid-consuming utilities of the northeast would feel the shortage within a few weeks. 
Therefore, the implementation of the Federal and state measures will probably not be uniform across the nation.

Specific regional vulnerabilities of energy systems to demand, supply, and distribution problems are the focus of the emergency information systems described in a later section of this plan. Each of these systems will monitor demand, supply, and inventories for each fuel on a state-by state basis. While it would be impossible to describe all combinations of events which would lead to an energy emergency in each state or region, the information systems to be establish up for the winter should identify impending state and regional energy problems before they become critical. 


\subsection{Crisis Management}

\subsection{Implementation Guidelines}

These implementation guidelines for addressing shortages of natural gas, petroleum, electricity, coal, and propane are intended to assist policy-makers at the time of a shortage. They represent the set of potential measures which could offset the impact of a shortage, and indicate the order in which the measures might be implemented. During a shortage, it will be necessary to modify the guidelines to respond to specific circumstances including the level and geographic distribution of shortfall for each energy type, duration, season and weather, available legal authority, and economic conditions.

A successful response to an energy shortage depends on coordination in the planning and implementation of emergency measures by governments, industry, and private consumers. While these guidelines focus on the response of the federal government, assumptions regarding the actions of other entities are based on direct communications with them and a review of documented plans. The federal response will consist of the implementation of specific measures to offset the impact of a shortage; and the monitoring, coordination, and evaluation of the national response to an emergency.

This section consists of six parts. The first part describes the general principles of the implementation guidelines and the manner in which they are likely to be used. The following four parts describe the specific elements of the guidel ines with respect to natural gas, petroleum, electricity and coal, and propane shortages. The last part. discusses the gufdelines for impact assistance programs.

\subsubsection{Basic Principles}

More than 50 government actions to respond to an energy shortage have been included in this plan, which may be implemented at the federa1, state, and local level. Also, most major energy consuming industries have developed contingency plans for shortages. Given such preparations, it is essential to establish principles governing the sequence and timing of the measures. The four principles governing the implementation guidelines are the following:

(1) Prevention of Unnecessary Hardship and Threats to Health and Safety. Energy shortages may most severely impact individuals in particular geographic areas and/or income classes. State and/ or federal measures should be implemented in a timely manner to prevent conditions in which individuals are economically or physically deprived of fuel for home heating, and other essential uses. 
(2) Reliance on States and the Private Sector to Respond to Relatively Mild Shortages. In general, measures implemented by states and industry should be relied on when energy shortages are relatively mild. State measures may more accurately address the level of shortfall within each state and represent the consumption preferences of its population. For example, tradeoffs between consumption of energy for industrial production to prevent unemployment and consumption of energy for home heating can be made more effectively at the state level. However, when shortages fall disproportionately on a few states, federal measures may be implemented.

(3) Preference for Voluntary Rather Than Mandatory Measures. To the extent possible, measures which rely on the voluntary compliance of producers, distributors, retailers, and consumers should be implemented before those which entail the force of law. Voluntary measures have.less impact on normal business practices and decisions, and on the consumption preferences of individuals; entail less government intervention; can be implemented more quickly; and are less difficult and costly to maintain.

(4) Minimizing the Economic Impact of the Shortage. Reductions in the supply of energy available to industry for production and space heating will result in decreases in output, employment, and national income and increased dependence on income maintenance programs. To the extent possible, scarce energy supplies can be redirected among industrial end-users so as to minimize national and regional economic impact.

\subsubsection{Generà 1 Guidel ines}

The number of potential energy shortage scenarios is too large to makc it feasible to develop customized implementation guidelines for each. It is more practical to establish a modular set of guidelines which designate sets of measures which may be implemented when certain types of shortage conditions occur. Specifically, the implementation guidelines consist of four phases for each of five types of energy for which a shortage may occur this winter - natural gas, petroleum, electricity and coal, and propane.

The four phases generally correspond to shortfall levels. It is recognized that during a shortage the magnitude of the shortfall is not the only factor which determines the measures to be implemented. However, national and regional shortfalls probably are the most important factors. Grouping measures with respect to shortfall levels is a useful conceptual framework for guiding the decisions of policy-makers. The four phases are not intended as an inflexible strategy which responds to shortages only on the basis of shortfall levels. Fach of the four phases consists of a number of measures which 
may be implemented by federal and state governments; as well as actions to implement the elements of the federal Energy Emergency Center (EEC) and emergency energy information systems. The general characteristics of each of the four phases, regardless of energy type, are described below. A summary of the guidelines for each energy type, is presented in Exhibit 2.1.1. Each of the measures referenced in the exhibit are described in detail in Section 3.0

- Phase I: Prior to Shortage.

Phase I is currently in effect and will continue in effect until a likely shortage is identified. It is a period during which a wide variety of contingency measures are implemented to increase the state of readiness for an energy shortage. Actions are taken to increase inventory levels either by short term increase in production or imports, or by reducing current consumption. Also, during this phase efforts are made to secure 1egal authority for mandatory federal and state measures; coordinate federal and state contingency plans; implement energy information systems to monitor energy supply and demand and produce timely forecasts, as well as systems to incorporate weather information in energy planning and forecasting; and arrange for special facilities and equipment for operations of the Energy Emergency Center.

- Phase II: Mild Shortage.

Phase II is implemented when a relatively mild shortage is experienced. The precise level of shortfall associated with Phase II for each energy type may vary, but in no.case will it exceed approximately $10 \%$ of unconstrained demand in any region. I In some cases, the shortfall will be relatively evenly distributed, affecting to some extent all states which are primary consumers of the source of energy. For the lowest shortfall levels, there will be almost complete reliance on measures implemented by states and industry. At somewhat higher levels, the Federal Government may implement supply increase measures and programs designed to achieve voluntary reductions in consumption; and, when appropriate, encourage mandatory artions by the states (e.g. , intra-state redirection of natural gas). In other cases, the national shortfall may be relatively low, but the location of the shortfall may primarily impact specific states or a single region. These circumstances are most likely to arise from locally severe weather or a disruption in the distribution system. In these cases, the Federal Government will supplement. normal measures associated with this phase with those which act to facilitate emergency transportation of energy supplies and/or redistribute available supplies among states. During a mild shortage, many of the functions of the Energy Emergency Center will be implemented with relatively low levels of effort. Special data collection procedures will be implemented on an exception basis to more effectively monitor actual or potential local shortages.

1/ For natural gas, phases are defined in terms of FPC curtailment priorities. 


\begin{tabular}{|c|c|c|c|c|}
\hline $\begin{array}{r}\text { ENERGY } \\
\text { TYPE }\end{array}$ & NATURAL GAS & PETROLEUM & ELECTRICITY/COAL & PROPANE \\
\hline $\begin{array}{l}\text { PHASE } 1 \\
\text { PRIOR TO } \\
\text { SHCRTAGE }\end{array}$ & $\begin{array}{l}\text { - Maximize Storage Levels } \\
\text { - Factlitate increased } \\
\text { Imports of Natural Gas } \\
\text { when they become needed } \\
\text { - Encourage Development of } \\
\text { State Operated Fuel Ex- } \\
\text { change Programs } \\
\text { - Issue Special Rule for } \\
\text { Ethane-Propane Mixture }\end{array}$ & $\begin{array}{l}\text { - Establish a Middle Dis- } \\
\text { tillate State Set-Aside } \\
\text { Program }\end{array}$ & $\begin{array}{l}\text { - Provide Assistance to } \\
\text { Electric utilities in } \\
\text { Developing Contingency } \\
\text { Plans and Agreements }\end{array}$ & $\begin{array}{l}\text { - Clarify Position on In- } \\
\text { creased Imports for } \\
\text { Winter } \\
\text { - Fully Implement Exist- } \\
\text { ing Restrictions on Use } \\
\text { of Propane as Aiternate } \\
\text { Fuel for "Less Essential } \\
\text { Uses" } \\
\text { - Issue on standby basis } \\
\text { special rule for emer- } \\
\text { gency allocation }\end{array}$ \\
\hline : & \multicolumn{4}{|c|}{$\begin{array}{l}\text { IMPLEMENT APPLICABLE MEASURES DESIGNATED FOR PHASE I } \\
\text { IMPLEMENT MODEST FEDERAL PUBLIC INFORMATION PROGRAM }\end{array}$} \\
\hline $\begin{array}{l}\text { PHASE II } \\
\text { MILD } \\
\text { SHORTAGE }\end{array}$ & $\begin{array}{l}\text { - Activate Demand } \\
\text { Restraint Program for } \\
\text { Federal Facilities } \\
\text { - Accelerate Production } \\
\text { from Federal Lease } \\
\text { - Authorize Emergency } \\
\text { Sales Arrangements } \\
\text { - Monitor Natural Gas } \\
\text { Curtailment Programs }\end{array}$ & 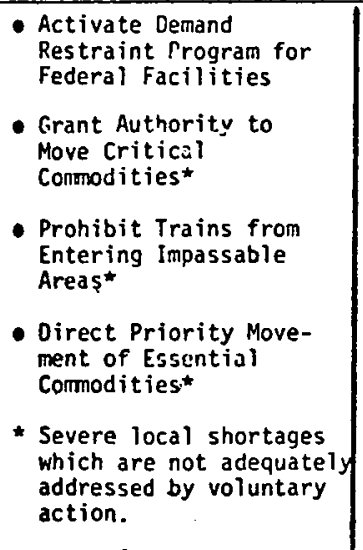 & $\begin{array}{l}\text { - Activate Demand } \\
\text { Restraint Program for } \\
\text { Federal Facilities } \\
\text { - Encourage Power } \\
\text { Wheel ing and Similar } \\
\text { Transmissions Wher- } \\
\text { ever Local Shortages } \\
\text { are not Being Ade- } \\
\text { quately Addressed }\end{array}$ & $\begin{array}{l}\text { - Issue Temporary } \\
\text { Authority to Move } \\
\text { Critical Commodities" } \\
\text { - Oirect Railroads to } \\
\text { Give Priority to } \\
\text { Movement of Fuel and } \\
\text { Other Essential } \\
\text { Commodities" } \\
\\
\text { For severe local } \\
\text { shortages which are not } \\
\text { adequately addressed by } \\
\text { voluntary action }\end{array}$ \\
\hline \multicolumn{5}{|c|}{$\begin{array}{l}\text { IMPLEMENT APPLICGULE MEASURES DESIGNATED FOR PHASE II } \\
\text { IMPLEMEIT ENHANCED FEDERAL PUBLIC INFORMATION PROGRAM }\end{array}$} \\
\hline $\begin{array}{l}\text { PHASE III } \\
\text { MODERATE } \\
\text { SHORTAGE }\end{array}$ & $\begin{array}{l}\text { - Pre-empt Reserve Gas in } \\
\text { OCS } \\
\text { - Reallocate Royalty Gas } \\
\text { from Federal Lanós } \\
\text { - Prohibit Use of Natural } \\
\text { Gas as a Boiler Fuel (as } \\
\text { practical) } \\
\text { - Ban Outdoor Gas Lamps }\end{array}$ & $\begin{array}{l}\text { - Implement Product } \\
\text { Entitlement Programs } \\
\text { - Suspend Driver Hours of } \\
\text { Service Requirements } \\
\text { - Defer Vehicle Regis- } \\
\text { stration Requirements }\end{array}$ & $\begin{array}{l}\text { - Load Shedding at } \\
\text { Gaseous Diffusion } \\
\text { Plants } \\
\text { - Temporary Modification } \\
\text { of Coal Conversion } \\
\text { Orders }\end{array}$ & $\begin{array}{l}\text { - Implement Procedure } \\
\text { for Emergency Alloca- } \\
\text { tion of. Propane }\end{array}$ \\
\hline \multicolumn{5}{|c|}{$\begin{array}{l}\text { IMPLEMENT APPLICABLE MEASURES DESIGNATED FOR PHASE III } \\
\text { IMPLEMENT MAJOR FEDERAL PLBLIC INFORMATION PROGRAM }\end{array}$} \\
\hline $\begin{array}{l}\text { PHASE IV } \\
\text { SEVERE } \\
\text { SHORTAGE }\end{array}$ & $\begin{array}{l}\text { - Establish Mandatory } \\
\text { Thermostat Levels for } \\
\text { Commercial. Buildings } \\
\text { - Activate Energency } \\
\text { Measures Under the } \\
\text { Defense Production Act } \\
\text { - Allocate Natural Gas to } \\
\text { Ensure Health, Safety } \\
\text { and Protection of } \\
\text { PruperLy }\end{array}$ & $\begin{array}{l}\text { - Impose Revised Alloca- } \\
\text { tion Program for } \\
\text { Petroleum Piroducts } \\
\text { Which Have Been } \\
\text { Decontrolled } \\
\text { - Orawdown Strategic } \\
\text { Reserves } \\
\text { - Establish Mandatory } \\
\text { Refinary Yield Frogram } \\
\text { - Mandate Thermostat } \\
\text { Levels for Commerical } \\
\text { Buildinas } \\
\text { - Obtain Emernency Trans- } \\
\text {-portation Priority and } \\
\text { Allocation Authority } \\
\text { - Obtain Icc Authorlty } \\
\text { Ovrr Privotely Owned } \\
\text { Rallcars } \\
\text { - Halve the Jones Act } \\
\text { as necessary }\end{array}$ & $\begin{array}{l}\text { - Mandate Electricity } \\
\text { Transmission Between } \\
\text { Regions } \\
\text { - Temanrary Suspension of } \\
\text { Clean Air Implementa- } \\
\text { tion } \\
\text { - }\end{array}$ & $\begin{array}{l}\text { - Expand ICC standby } \\
\text { Authority to Include } \\
\text { Private Railcars } \\
\text { - Waive the Jones Act } \\
\text { as necessary }\end{array}$ \\
\hline
\end{tabular}


- Phase III: Moderate Shortages.

Shortfalls which locally exceed $10 \%$ of unconstrained demand would be considered moderate. The shortfalls which result from the scenarios described in Section 1.3 generally fall within this range. State measures, supply increase measures, and federal voluntary demand restraint measures may be inadequate to offset the shortfall. Phase III may be characterized by the implementation of relatively severe demand restraint measures at the state level and supply allocation measures. Allocation measures will be particularly important as a means of addressing differences in shortfall among states. Emergency transportation measures will be relied on when local shortfalls are attributable to severe weather conditions and disruption of normal distribution systems. All units and functions of the Energy Emergency Center will be implemented. A number of emergency procedures will be implemented with respect to information systems and forecasting. Among the most significant procedures are increased frequency of regular reports; special data collection efforts, many of which will be telephone surveys; increased frequency of supply, demand, price, and consumption forecasts for all energy types; and preparation of daily as well as weekly status reports.

\section{- Phase IV: Severe Shortage.}

Severe shortfalls which exceed $10 \%$ of national unconstrained demand may trigger the implementation of relatively extreme measures by the Federal Government. At severe shortfall levels it may be desirable to use high cost increases in supply, allocate supplies to maintain health and safety, and implement extreme mandatory demand restraint measures. During Phase IV, all units of the Energy Emergency Center will be operational and functioning at near maximum capacity. Energy and program information systems will be fully implemented to respond to emergency conditions.

The measures included in the four phases described above directly address aggregate and regional supply and demand for energy. They attempt to influence or replace market forces to achieve a distribution of scarce energy supplies which prevents unnecessary hardships and threats to health and safety; and which may reduce the economic impact of the shortage. However, there are a number of impact assistance measures which directly act to reduce the economic impact of a shortage on those geographic areas or income classes most severely affected. Examples of this type of measure are emergency assistance to low-income individuals and families for payment of fuel bills, and emergency food stamps during an energy shortage. Implementation of these measures does not depend on the severity of the shortfall. The triggering mechanism for these measures will depend on a relatively complex set of variables which assess need. As a result, it is conceivable for any of the impact assistance measures to be implemented during phases II, III, or IV. In effect, a separate trigger will exist for each assistance measure, 
It is anticipated that the integrated implementation guideline's described in succeeding sections will be used in the following manner. When it becomes clear that a shortage of an energy source is imminent, the "equilibrium" level of shortfall for all energy types will be projected. The shortage may be attributable to a combination of factors, such as an embargo during an abnormally cold winter, but a single set of shortfalls will be projected. Projections will be based on the assumption that when a shortage of an energy type develops, substitution will occur which may act to spread the shortage across several types of energy. Based on the projected shortfall for each type of energy, sets of energy-specific measures will be considered. The result of this process could easily be a situation in which Phase IV measures are implemented for petroleum, while Phase II and Phase III measures are implemented for electricity and natural gas, respectively. It should be emphasized that while the level of shortfall will determine the phase of the implementation guidelines, the specific measures associated with the phase which actually will be implemented will largely depend on the specific circumstances associated with the shortfall. Also, it has been assumed that legal authority to implement each of the measures will be available or obtained at the time it is required.

\subsubsection{Implementation Guidelines for Natural Gas Shortages}

The implementation guidelines for natural gas shortages consist of four phases. However, the events which precede each phase and the actions associated with each phase are relatively unique. In the absence of an abnormally warm winter, it is certain that there will be a shortage of natural gas which will at least result in local curtailments. While primarily related to planning, Phase I consists of some measures which immediately affect supply and demand and are predicated on the assumption of a winter shortage. Phase II actions have a potentially significant impact on supply, and emphasize moderate redistribution of supplies to mitigate the most severe effects of the shortage. It is presumed that curtailments are generally an effective means of addressing mild shortages. Phase III consists of a number of measures which increase supply, reduce demand, and provide a means of affecting the distribution of the shortage. Phase IV primarily consists of the implementation of emergency programs under the authority of the Defense Production Act in addition to almost all measures which would have been implemented

for less severe shortages. It should be emphasized that throughout Phase II, III, and IV FERC will continue to conduct a wide range of activities associated with natural gas curtailments as mandated by the Natural Gas Act. Exhibit 2.1.2 displays the implementation guidelines for natural gas shortages.

\section{- Phase I: Prior to a Natural Gas Shortage.}

Actions to be taken during Phase I are based on the assumption that a natural gas shortage is imminent. Natural gas curtailments of 1.8 Tcf are estimated for a normal winter. The Federal Government has taken steps to increase the supply of natural gas which will be available and to bring to a higher state of readiness plans for the many measures required to address more severe shortages. 
EXHIBIT 2.1.2

IMPLEMENTATION GUIDELINES FOR NATURAL GAS SHORTAGES

\begin{tabular}{|c|c|c|}
\hline \multirow{3}{*}{$\begin{array}{l}\text { PHASE I } \\
\text { PRIOR TO } \\
\text { SHORTAGE }\end{array}$} & $\begin{array}{l}\text { STATE } \\
\text { ACTIONS }\end{array}$ & $\begin{array}{l}\text { Implement public information program. } \\
\text { Plan fuel exchange programs, demand restraint measures, and intrastate } \\
\text { allocation of natural gas; and secure necessary legal authority. } \\
\text { Plan management of localized shortages, and coordination with the Federal } \\
\text { government and private industry. }\end{array}$ \\
\hline & $\begin{array}{l}\text { FEDERAL } \\
\text { ACTIONS }\end{array}$ & $\begin{array}{l}\text { Maximize storaqe levels. } \\
\text { Encourage increased imports of natural gas. } \\
\begin{array}{|l}\text { Issue special rule for ethane-propane mixture. } \\
\text { Encourage development of state operated fuel exchange programs. } \\
\text { Prepare handbook for federal assistance during energy emergencies. } \\
\text { Draft legislation, regulations, executive orders, procedures, etc., to } \\
\text { support measures which may be implemented during Phases II, III, or IV. }\end{array}\end{array}$ \\
\hline & $\begin{array}{l}\text { ENERGY } \\
\text { EMERGENCY } \\
\text { CENTER AND } \\
\text { INFORMATION } \\
\text { SYSTEMS }\end{array}$ & $\begin{array}{l}\text { Prepare the design of the Energy Emergency Center (EEC) and secure } \\
\text { facilities and equipment. } \\
\text { Implement new or modified information systems to effectively monitor } \\
\text { market activity and to identify aggregate and/or local shortages: } \\
\text { increase reporting frequency of natural gas storage systems; and review } \\
\text { curtailment plans. } \\
\text { Plan special data collection procedures to be implemented when natural } \\
\text { gas shortages oceur. }\end{array}$ \\
\hline \multirow{3}{*}{$\begin{array}{l}\text { PHASE II } \\
\text { MILD } \\
\text { SHORTAGE }\end{array}$} & $\begin{array}{l}\text { STATE } \\
\text { ACTIDNS }\end{array}$ & $\begin{array}{l}\text { Activate fuel exchange plans (where appropriate). } \\
\text { Implement voluntary demand restraint measures (e.g., reduced business } \\
\text { hours, lowcr temperaturns, for buc inessos and residences). } \\
\text { Incredse scupe alld filleis lity ur pullic information program. } \\
\text { Redirect intrastate supplies among distributors. }\end{array}$ \\
\hline & $\begin{array}{l}\text { ГEDCRAL } \\
\text { ACTIONS }\end{array}$ & $\begin{array}{l}\text { Implement all Phase I measures (except maximization of storage levels). } \\
\text { Implement demand restraint program for federal facilities. } \\
\text { Accclcratc production from foderal leases. } \\
\text { Authorize temporary sales arrangements. }\end{array}$ \\
\hline & $\begin{array}{l}\text { ENERGY } \\
\text { EMERGENCY } \\
\text { CENTER AND } \\
\text { INFORMATION } \\
\text { SYSTEMS }\end{array}$ & $\begin{array}{l}\text { Implement EEC internal and external communications functions, } \\
\text { Implement supplemental data collection mechanisms such as telephone } \\
\text { surveys of distributors on an exception basis (primarily to address } \\
\text { state and/or regional shortages). } \\
\text { Increase frequency of forecasts regarding national and local market } \\
\text { collidiloris. }\end{array}$ \\
\hline \multirow{3}{*}{$\begin{array}{l}\text { PHASE III } \\
\text { MODERATE } \\
\text { SHORTAGE }\end{array}$} & $\begin{array}{l}\text { STATE } \\
\text { ACTIONS }\end{array}$ & $\begin{array}{l}\text { Implement all measures designated for Phase II. } \\
\text { Implement severe demand restraint measures. } \\
\text { Implement intensive public information programs. }\end{array}$ \\
\hline & $\begin{array}{l}\text { FEDERAL } \\
\text { ACTIONS }\end{array}$ & $\begin{array}{l}\text { Implement all measures designated for Phase II. } \\
\text { Allocate llatural gas to ensure hedilh, safuly, and protection of property. } \\
\text { Pre-empt reserve gas in ocS. } \\
\text { Reallocate royalty gas from federal lands. } \\
\text { Prohibit use of natural gas as boiler fuel (as practical). } \\
\text { Ban outdoor gas lamps. }\end{array}$ \\
\hline & $\begin{array}{l}\text { ENERGY } \\
\text { EMERGENCY } \\
\text { CENTER AND } \\
\text { INFORMNTION } \\
\text { SYSTCHS }\end{array}$ & $\begin{array}{l}\text { Implement all EEC functions incluoing Internal and external conmunica- } \\
\text { tfons, state and local government liaison, interagency coordination, } \\
\text { and integration of contingency measures. } \\
\text { Implement all supplementary data collection efforts including telephone } \\
\text { surveys of distributors and/or large end-users; weekly reporting of } \\
\text { underground storage; and/or systematic monitoring of curtailments. } \\
\text { Increase frequency of natural and regional forecasts of supply dilu } \\
\text { demand for natural gas. }\end{array}$ \\
\hline \multirow{3}{*}{$\begin{array}{l}\text { PHASE IV } \\
\text { SEVERE } \\
\text { SHORTAGE }\end{array}$} & $\begin{array}{l}\text { SIATE } \\
\text { ACTIONS }\end{array}$ & Implement measures designated for Phase III. \\
\hline & $\begin{array}{l}\text { FEDERAL } \\
\text { ACTIONS }\end{array}$ & $\begin{array}{l}\text { Implement all Federal measures designated for Phase III. } \\
\text { Establish mandatory thermostat levels. } \\
\text { Activate emergency measures under the Defense Production Act. }\end{array}$ \\
\hline & $\begin{array}{l}\text { FEDERAL } \\
\text { COORDINATION } \\
\text { CENTER AND } \\
\text { INFORMUTION } \\
\text { SYSTEMS }\end{array}$ & $\begin{array}{l}\text { Take actions designated for Phase IIl except scope and magnitude of } \\
\text { supplementary data collection may be increased; and frequency of } \\
\text { forecasts will be increased. }\end{array}$ \\
\hline
\end{tabular}


States should be particularly active during Phase I. At a minimum, it will be necessary to monitor and evaluate curtailment plans to determine the impact on the state of various shortfall levels. Also, it is important to review the circumstances which could inhibit the implementation of a curtailments program and/or reduce its anticipated impact in some states. It may be desirable to institute curtailments immediately to increase natural gas storage levels and ensure that curtailed end-users make arrangements for alternate fuels prior to an actual shortage. With the possible exception of a public education program, it is not anticipated that states will implement any other significant programs during Phase I.

Contingency planning by states during Phase I should focus on the development of effective measures to be implemented during later phases, and on the institution of effective means of coordinating state actions with those of the Federal Government and private industry. Particularly important measures to be developed during this phase include intrastate fuel exchange, demand restraint measures which rely on voluntary compliance or local enforcement, and the intrastate allocation of natural gas. Legal authority to implement these measures must be secured at the earliest possible time.

The most important steps for the Federal Government in Phase I will be to increase inventories of natural gas and promulgate regulations needed to carry out measures in later phases (e.g. allocation lease production) and closely monitor industry storage and drawdown plans and actions. Ideally, this would be achieved by persuading producers to increase output, distributors to increase inventories, and end-users to reduce consumption. However, beginning in September storage levels have been monitored and if fill rates are too low, orders to increase the fill rates may be issued under the Natural Gas Act. Despite such orders and availability of substantial excess capacity, the amount by which fill rates could be increased in the short run is uncertain.

The remaining two federal measures for which implementation may be begun during Phase I will increase natural gas supplies by a maximum of $2 \%$. The two measures are as follows:

- Increase imports of natural gas from Canada and Mexico by expediting the processing of requests for importation.

- Promulgate a special rule which would permit ethane-propane mixtures which contain more than $10 \%$ propane to be sold to distribution companies having propane-air plants.

Federal preparations for managing a shortage of natural gas will be relatively modest during Phase I. Facilities and equipment for the Energy Emergency Center (EEC) will be identified. Energy information systems will monitor market conditions and prepare timely forecasts of supply and demand conditions. 
- Phase II: Mild Natural Gas Shortage.

Mild shortages of natural gas will occur when there are widespread curtailments of priority 4-9 consumers, with only spot curtailments of priority 3 users. In the context of the scenarios developed in Section 1.3, Phase II actions probably would be implemented during a winter in which normal weather conditions are experienced, or during an embargo when fuels switching occurs automatically by the actions of consumers.

Actions at the state level will be relied on to respond to mild natural gas shortages. It is assumed that each state can implement measures to significantly reduce consumption, and equitably spread the balance of the shortfall. States may primarily implement voluntary and mandatory demand restraint measures by executive order. Programs which may be implemented pertain to reducing the hours of business and commercial establishments, reducing the energy consumption of state and local governments, residential and commercial thermostat guidelines, and more intensive public education programs. Also, states may implement intrastate fuel exchange plans using the 60-day emergency sales authority permitted by FERC.

The most significant measure which may be implemented by states will be the redirection of natural gas within a state. Many states already have this authority by acts of their legislatures and can implement such a program at their discretion. DOE. has encouraged all states potentially affected by a natural gas shortage to establish this type of emergency authority.

Federal measures which would be implemented during a mild natural gas shortage would have minimal impact, except when there is a severe shortfall in a state(s) or region. Specifically, the Federal Government may accelerate production from federal leases, and implement the demand restraint program for federal facilities, in addition to the federal measures listed under Phase I. I/ Depending on the severity of shortages in specific states or regions, the Federal Government may permit temporary sales agreements. This may increase available supplies by as much as $3 \%$.

The federal actions with respect to the Energy Emergency Center and energy information systems will reflect a relatively low level of federal involvement in mild natural gas shortages. Among the EEC functions which will be implemented during Phase II are monitoring the actions of state and local governments and providing assistance where applicable; coordinating the implementation of specific measures within the DoE; and providing public information regarding the nature of the shortage and federal and state actions. During Phase II, there will be several modifications to the normal data collection and forecasting strategy. Supplementary data regarding state and/or regional supply and demand conditions will be collected systematically, but on an exception basis. For example, in states experiencing an. abnormally large shortfall, a daily telephone survey of distributors will be required. Also, based on supplementary data regarding supply and demand, and weather conditions, more frequent forecasts of the level of shortfall and market conditions will be prepared.

I/ Under most scenarios in which a mild shortage triggers the implementation of Phase II measures, there would be no opportunity to increase inventories. 
Phase III: Moderate Natural Gas Shortage.

An aggregate natural gas shortfall in which there is widespread curtailment of priority 3 consumers and spot curtailments of priority 2 will be considered a moderate shortage. In contrast to Phases I and II, the Federal Government will assume a much more active role in addressing the shortage. The general federal strategy will be to reduce the aggregate shortfall to the lowest possible level given economic and technological constraints, and to distribute the shortage in a manner which protects health and safety and is equitable with respect to states and regions. Also, during this phase the Energy Emergency Center and any emergency information systems related to natural gas will be fully implemented.

In general, the measures to be implemented by states during Phase II also would be implemented during Phase III. Emphasis may be placed on demand restraint measures and redirection of supplies among intrastate distributors. However, it is likely that some of the more severe demand restraint measures would be implemented more frequently during Phase III.

The Federal Government will implement a variety of measures during a moderate natural gas shortage. All measures which would be implemented to respond to aggregate shortfalls in Phase II would be implemented. However, four federal measures wi il be particularly important and should equalize effective demand and supply.

- Pre-empting gas in OCS which is being reserved for later production will increase supplies by as much as $8.0 \mathrm{Bcf} /$ Month.

- Reallocating royalty gas from federal lands among pipel ine companies could reduce regional shortages but may be relatively difficult to implement.

- Ban on the use of natural gas for outdoor lighting. Authority for this measure would be provided by the National Energy Act.

- Prohibiting the use of natural gas as a boiler fuel when alternative fuels are available will achieve a reduction in natural gas consumption of at least $50 \mathrm{Bcf} /$ Month. This will require submission of a contingency plan to Congress or special legislation. The benefits of this measure are significantly diminished if there is a simultaneous shortage of petroleum products and/or coal. 
The Energy Emergency Center will be fully operational during a moderate shortage. The severity of the shortage and the extent of the federal response will require the EEC to perform al1 eight of its energy emergency related functions. Adjustments to energy information systems and forecasts would be the same as those outlined for Phase II. The main difference would be that the magnitude and scope of the supplementary data collection effort would be greater, and regional market forecasts would be more numerous and frequent.

- Phase IV: Severe Natural Gas Shortage.

Generally, widespread curtailments of users in priority 2 with the threat of curtailments to priority 1 will be considered severe natural gas shortages. The implementation guidelines for Phase IV will be the same as that for Phase III with two basic exceptions. Allocation of natural gas for high priority uses will occur, per Section 4 of an extended Emergency Natural Gas Act. Also, mandatory maximum thermostat levels may be established for space heating and cooling, and heating water in most non-residential buildings. Comprehensive plans for a program of this type were developed by mandate of EPCA but have not as yet been submitted to Congress for approval. However, given the difficulty of enforcing the measure, and the uncertainty of its incremental impact in combination with all other federal and state measures, it is unlikely. that it would be implemented unless the level of shortfall was extremely severe.

\subsubsection{Implementation Guidel ines for Petroleum Shortages}

The implementation guidelines for petroleum incorporate lessons learned during the Arab oil embargo of 1973-74 and the frequent and comprehensive embargo contingency planning which has been conducted since that crisis. More specifically, petroleum shortages are most likely to result from disruptions of state or local distribution systems or interruptions in the supply of imports which create large shortfalls. Therefore, emphasis is placed on extensive planning and high impact measures which can be implemented quickly.

The implementation guidelines for petroleum consist of four phases. In Phase I, emphas is will be placed on comprehensive planning and increases in product inventories. Measures in Phase II will be implemented for mild aggregate or moderate state or local shortages. Demand restraint measures at the state level will be relied on for aggregate shortages, while transportation measures primarily will respond to state and/or local shortages attributable to severe weather conditions. Phase 111 would be implemented for moderate shortages affecting several regions and would rely on an allocation program. However, Phase III also would include federal supply increase and demand restraint measures.

Phase IV would be implemented only a severe widespread shortages, resulting from a severe energy supply interruption as defined in the Energy Poilicy and Conservation Act. 
- Phase I: Prior to a Petroleum Shortage.

The actions to be taken in preparation for a petroleum shortage include increased monitoring of supplies, setting up of procedures for increased coordination, and revising or establishing programs to be implemented in later phases. These include the petroleum allocation regulations, state set-aside program, and establish of strategic reserves, all of which have long planning lead times.

Prior to a shortage, state agencies should review voluntary and mandatory demand restraint measures to ensure that they will be effective and can be implemented efficiently. Many such measures have been implemented at some time during the last three years so, in most cases, only minor modifications will be required. In a few states, recent legislation has substantially increased the capacity of the government to respond to shortages, and plans for new measures are being developed. Experience indicates that the actions most frequently implemented by states include reduced business hours, ban on outdoor lighting, enforcement of speed limits, reduced hours for gasoline retailers, reduced use of state vehicles, school closings, emergency carpooling programs, and increased availability of public transportation.

When promulgated, will establish a set-aside of $4 \%$ of total monthly supply within a state which may be distributed to prevent hardships on end-users who cannot secure supplies by normal means.

Since increases in inventories must be voluntary, federal actions will attempt to alter the expectations of large consumers by highly publicized requests for voluntary increases, development of close working relationships with industry associations, and direct requests to exceptionally large distributors and consumers. A second measure, establishing a middle distillate state set-aside, was found to be successful during previous shortages. Special Rule \#5 promulgated in November 1977 , established a set-aside of $4 \%$ of total monthly supply within a state which may be distributed to prevent hardships on endusers which cannot secure supplies by normal means.

Actions with respect to the Energy Emergency Center (EEC) and energy information systems were initiated on 0ctober 1 . A general design of the EEC has been prepared as have plans for supplementary data collection and more frequent forecasting during a shortage. To the extent that EEC facilities and equipment will be secured prior to an actual shortage, and modifications will be made to existing energy information systems, these tasks will be completed during Phase I.

\section{Phase II: Mild Petroleum Shortage.}

During a mild petroleum shortage, measures implemented by individual states will be relied upon unless a specific state or region suffers a severe shortage due to abnormal weather conditions and/or a disruption of the distribution network. State and federal measures designated for Phase II would be adequate to respond to a maximum aggregate shortfall of less than $10 \%$. 
Primarily voluntary demand restraint measures may be implemented by states during Phase II to reduce consumption of gasoline and to some extent middle distillates. In addition to a moderate public education/information program, states may implement programs to lower thermostats in commercial establishments and residences, reduce business hours, increase the use of carpools, and increase the attractiveness of public transportation. The middle distillate set-aside program established prior to a shortage will be relied on to prevent any severe locial shortages within states.

Federal measures implemented during a mild aggregate petroleum shortage will.be limited to the demand restraint program for federal facilities and a national public education/information program. High impact measures will be reserved for severe state or regional shortages which cannot be adequately addressed by the cooperation of petroleum and transportation companies, I/ and federal and state governments. Under exlreme conditions, the Interstate Commerce Commission may direct the movement of critical commodities, prohibit trains from entering impassable areas, and/ or establish priorities for the movement of specified commodities.

If the mild shortage is precipitated by an international supply interruption which could quickly increase in magnitude, a number of actions related to crisis management and energy information systems will be taken. Specitically, the majorlty of EEC functions will becullie operational; weekly status reports will be prepared by DOE regional offices; and pre-implementation tasks will be performed for selected measures likely to be implemented for more severe shortages.

- Phase III: Moderate Petroleum Shortages.

Any scenario in which petroleum supplies locally fall short of unconstrained demand by more than $10 \%$ will be considered a moderate shortage and may require the implementation of a wide range of measures by federal' and state governments. The strategy for Phase III will consist of three steps: (1) implementation of supply increase and demand restraint measures for which authority is immediately available; and (2) implementatation of other measures affecting both supply. and demand, as legal authority is secured.

During a moderate shortage, states may implement the same types of measures as were designated for Hhase 11 , some of which may be made mandatory. Demand restraint measures most likely to be made mandatory are restrictions on gasoline sales and reductions in commercial 1 iyliting and heating.

Establishing temporary product entitlements to encourage increased imports of middle distillates will effectively increase affordable supplies during an embargo or an abnormally cold winter in which consumption of heating oil is much higher than normal.

1) Voluntary allocations administered by the petroleum industry are ex- pected to provide a degree of relief for shortages in Phase II: 
EXYIBIT 2.1.3

IMPLEMENTATION GUIDELIHES FOR PETROLEJH SHORTARESS

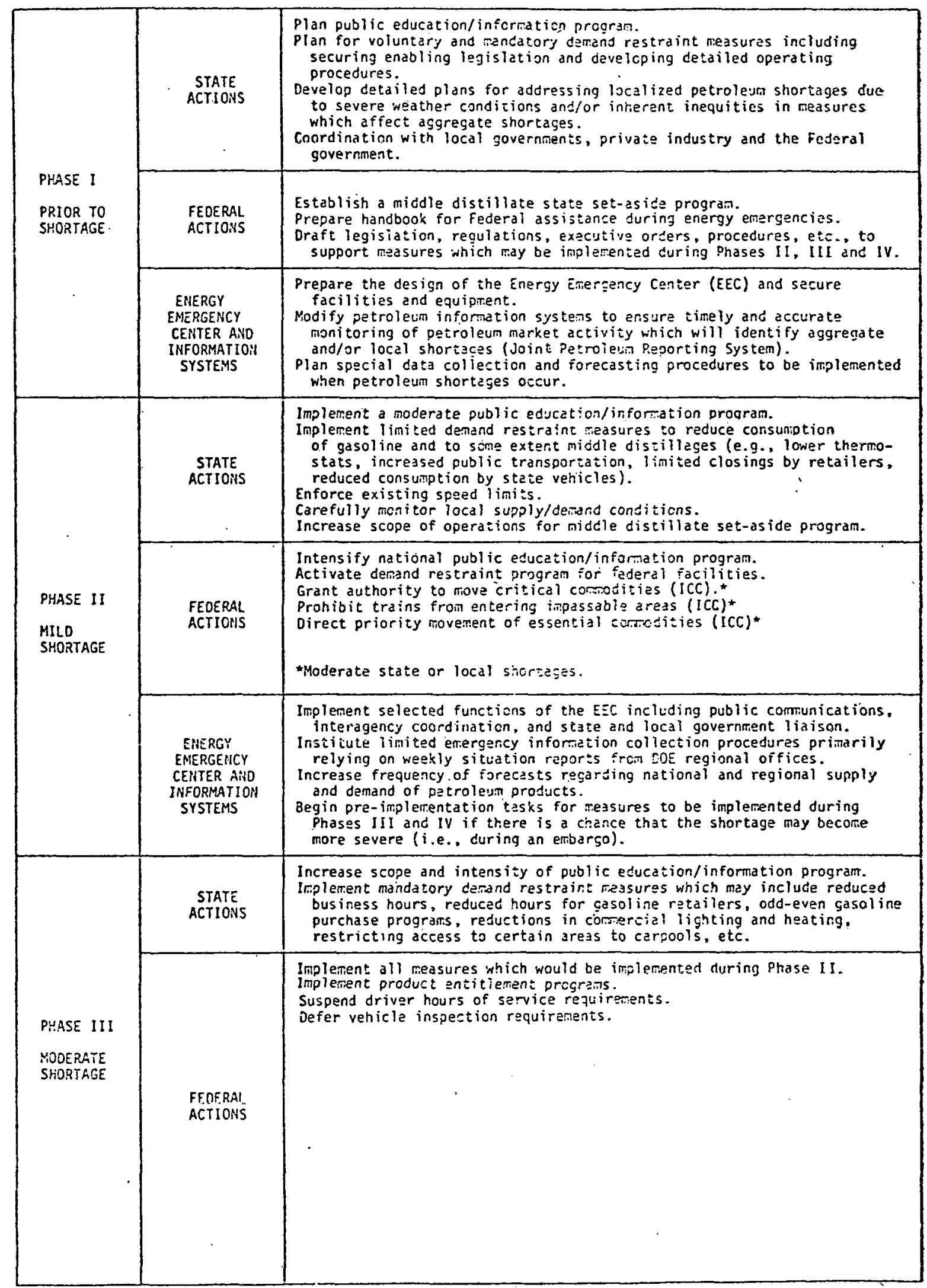


EXHIBIT 2.1.3. (continued)

\begin{tabular}{|c|c|c|}
\hline \multirow{3}{*}{$\begin{array}{l}\text { PHASE IV } \\
\text { SEVERE } \\
\text { SHORTAGE }\end{array}$} & $\begin{array}{c}\text { STATE } \\
\text { ACTIONS }\end{array}$ & Implement measures designated for Phase III. \\
\hline & $\begin{array}{l}\text { FEDERAL } \\
\text { ACTIONS }\end{array}$ & $\begin{array}{l}\text { Implement Federal measures designated for Phase III } \\
\text { Drawdown strategic reserves. } \\
\text { Establish mandatory refirery yield program } \\
\text { Mandate thenmostat levels (Conservation Contingency Plan yl). for } \\
\text { commercial buildings } \\
\text { Obtain emergancy transportation priority and allocation authority. } \\
\text { obtain ICC authority over privately owned railcars. } \\
\text { Impose ravised allocation prograin for petroleun products wilich have been. } \\
\text { decontrolleci. } \\
\text { Waive the Jones Act as necessary }\end{array}$ \\
\hline & $\begin{array}{l}\text { ENERGY } \\
\text { EMERGENCY } \\
\text { CENTER AIID } \\
\text { INFORMATION } \\
\text { SYSTEMS }\end{array}$ & $\begin{array}{l}\text { Implement actions designated for Phase III. } \\
\text { Implement and operate new information systems required to support } \\
\text { gasoline rationing. }\end{array}$ \\
\hline
\end{tabular}


A revised allocation program will be the primary means by which the Federal Government will respond to a moderate shortage. Products which have been decontrolled prior to a shortage can be made subject to allocation. The objective of the program will be to more equitably distribute available supplies.

During Phase III all functions of the EEC and all emergency petroleum information systems will be implemented. During moderate and severe shortages, especially those due to a supply interruption, federal coordination and information will be particularly important for ensuring an effective response.

\section{- Phase IV: Severe Petroleum Shortages.}

Federal measures which may be implemented during Phase IV either require enabling legislation or would have a relatively smal1 impact and, therefore, are considered to be of secondary importance. A measure requiring Congressional approval is mandatory thermostat levels. Such a measure probably will have been implemented at the state level so the expected incremental impact of the federal program is low. Also, a mandatory refinery yield program may be implemented which would have little impact on total supply, but could affect the relative supply of products.

In the event of a severe petroleum shortage, all functions of the EEC and all emergency petroleum information systems will be implemented. However, of more importance will be the tremendous effort required to implement communications, information systems, management operations, and imposition of a revised allocation program for all petroleum products.

The likelihood of implementing any Phase IV petroleum shortfall measures this winter is extremely remote. At this time the strategic petroleum reserve is too small to provide any significant offset to a major shortage. Although considerable work has been expended in the development of a gasoline rationing program, no plan is yet ready for submission to Congress.

\subsubsection{Implementation Guidelines for Electricity and Coal Shortages}

Although in some cases they are attributable to failures in generation or transmission systems, sustained electricity shortages are commonly attributable to shortages of fuels for power generation - natural gas, petroleum, and coal - and water for hydroelectric plants. These guidelines assume that even after measures are implemented to address shortages of those fuels, the electricity which can be generated may not be adequate to meet unconstrained demand. 
Because of the extent of interdependence between electricity and coal, measures to address coal shortages are incorporated in these guideTines. Currently, approximately $47 \%$ of electricity is produced by coalfired generators, Similarly, approximately $75 \%$ of coal production is used by utilities for the generation of electricity. Should an acute coal shortage be the result of a production slowdown, the implementation of the TaftHartley Act could be considered as a last resort.

The implementation guidelines for electricity and coal consist of four phases. In each phase, actions of states and utility companies are relied on. Only five federal measures are considered feasible and desirable, and they are recommended only for relatively severe shortages. During Phase I, emphasis is placed on the encouragement of agreements among electricity producers and/or distributors for sharing available supplies and instituting demand restraint measures. In the event of a mild shortage, many of the measures in the agreement are triggered, and states implement voluntary demand restraint measures. For a moderate shortage, more severe measures are taken by utilities, states may institute mandatory demand restraint measures, and the Federal Government acts to reduce its own consumption and increase fuel stocks. Phase IV is distinguished only by federal authority to mandate electricity transmissions between regions. Exhibit 2.1.4 summarizes the implementation guidelines for electricity shortages.

- Phase I: Prior to Electricity or Coal Shortages.

Prior to a shortage federal and state governments can assist intrastate and inters tate electricity producers and distributors in preparing cooperative strategies for addressing local shortages of fuel stocks and electricity. DOE has already distributed the PJM (Pennsylvania, New Jersy, Maryland) Coordinated Program for Redurtion in Energy Use to states and utilities to be used as an example. Other pools have also developed such plans. State utility commissions will be particularly instrumental in resolving issues regarding legal authority, transfer pricing, and coordination with state demand restraint measures.

Prior to a shortage, the Energy Emergency Center will operate in an anticipatory mode. Information systems developed by the former Federal Power Commission will. continue to be used to monitor the electric power supply and fuels situation.

\section{- Phase II: Mild Electricity and Coal Shortages.}

When a mild shortage is imminent, agreements among utilities will be activated and states may implement voluntary demand restraint measures. Measures implemented by utilities and states may be complementary and must be carefully coordinated to prevent inconsistencies. Among the measures which may be implemented by states and/or utilities are the establishment of voluntary consumption goals for each class of consumers, voluntary reductions in commercial and residential lighting, extensive public education/information with respect to methods of reducing electricity consumption, and reduced transmission to large consumers which are able to use alternate energy sources which are not in short supply. These measures would conservatively achieve reductions in demand of about $8 \%$. 
EXHIBIT 2.1.4

IMPLEMENTATION GUIOELINES FOR ELECTRICITY SHORTAGES

\begin{tabular}{|c|c|c|}
\hline \multirow{3}{*}{$\begin{array}{l}\text { PHASE I } \\
\text { PRIOR TO } \\
\text { SHORTAGE }\end{array}$} & $\begin{array}{l}\text { STATE AND } \\
\text { UTILITY } \\
\text { ACTIONS }\end{array}$ & $\begin{array}{l}\text { Encourage the development of agreements among intrastate and interstate } \\
\text { electricity producers and distributors for addressing an electricity } \\
\text { shortage. } \\
\text { ldentify localities most likely to be affected by electricity shortages. } \\
\text { resulting from shortages of coal or petroleum; and prepare plans for } \\
\text { responding to the shortages. } \\
\text { obtain legislative authority for emergency measures }\end{array}$ \\
\hline & $\begin{array}{l}\text { FEDERAL } \\
\text { ACTIONS }\end{array}$ & $\begin{array}{l}\text { Provide assistance to electric utilities in developing } \\
\text { contingency plans. } \\
\text { Prepare a handbook for Federal assistance during emergencies. }\end{array}$ \\
\hline & $\begin{array}{l}\text { ENERGY } \\
\text { EMERGENCY } \\
\text { CENTER AND } \\
\text { INFORMATION } \\
\text { SYSTEMS }\end{array}$ & $\begin{array}{l}\text { Prepare the design of the Energy Emergency Center (EEC) and secure } \\
\text { facilities and equipment. } \\
\text { Develop the Electric Power Sufficiency Monitoring System to be used to } \\
\text { analyze supply and demand conditions and identify potential shortages } \\
\text { for specific utilities. }\end{array}$ \\
\hline \multirow{3}{*}{$\begin{array}{l}\text { PHASE II } \\
\text { MILO } \\
\text { SHORTAGE }\end{array}$} & $\begin{array}{l}\text { STATE AND } \\
\text { UTILITY } \\
\text { ACTIONS }\end{array}$ & $\begin{array}{l}\text { Activate agreements among utilities for responding to shortages (e.g., } \\
\text { PJM Coordinated Program for Reduction in Energy Use). } \\
\text { Implement moderate public education/information program. } \\
\text { Voluntary reductions in residential and commercial lighting. } \\
\text { Institute consumption goals for each class of consumer. }\end{array}$ \\
\hline & $\begin{array}{l}\text { FEDERAL } \\
\text { ACTIONS }\end{array}$ & $\begin{array}{l}\text { Implement demand restraint program for federal facilities. } \\
\text { Encourage power wheeling and similar transmissions wherever local } \\
\text { shortages are not being adequately addressed. }\end{array}$ \\
\hline & $\begin{array}{l}\text { ENERGY } \\
\text { EMERGENCY } \\
\text { CENTER AND } \\
\text { INFORMATIDN } \\
\text { STSTEMS } \\
\end{array}$ & $\begin{array}{l}\text { Monitor utility fuel stocks which are in short supply, and perhaps in- } \\
\text { crease the frequency. of supply and demand forecasts. } \\
\text { Implement selective functions of the EEC if justified by the extent of } \\
\text { coal, petroleuin, or natural gas shortage. }\end{array}$ \\
\hline \multirow{3}{*}{$\begin{array}{l}\text { PHASE III } \\
\text { MODERATE } \\
\text { SHORTAGE }\end{array}$} & $\begin{array}{l}\text { STATE AND } \\
\text { UTILITY } \\
\text { ACTIONS }\end{array}$ & $\begin{array}{l}\text { Implement mandatory demand restraint measures with respect to residential } \\
\text { and commercial heating and/or lighting. } \\
\text { Institute consumption reduction goals for each class of consumer which } \\
\text { are higher than those in Phase II. } \\
\text { Implement procedures to reduce loss of electricity due to maintenance } \\
\text { and operating procedures of utilities. } \\
\text { Reduce transmissions to selected large consumers (for extreme local } \\
\text { shortages only). }\end{array}$ \\
\hline & $\begin{array}{l}\text { FEDERAL } \\
\text { ACTIONS }\end{array}$ & $\begin{array}{l}\text { Load shedding at } \quad \text { gaseous diffusion plants. } \\
\text { Temporarily modify coal conversion orders. }\end{array}$ \\
\hline & $\begin{array}{c}\text { ENERGY } \\
\text { EMERGENCY } \\
\text { CENTER AND } \\
\text { INFORMATION } \\
\text { SYSTEMS } \\
\end{array}$ & Implement measures designated for Phase II. \\
\hline \multirow{3}{*}{$\begin{array}{l}\text { PHASE IV } \\
\text { SEVERE } \\
\text { SHORTAGE }\end{array}$} & $\begin{array}{l}\text { STATE AND } \\
\text { UTILITY } \\
\text { ACTIONS }\end{array}$ & $\begin{array}{l}\text { Implement measures designated for Phase III; however, reduction and/or } \\
\text { suspension of transmission to selected consumers would be relied on } \\
\text { to a greater extent. } \\
\text { Temporarily suspend clear air implementation plans }\end{array}$ \\
\hline & $\begin{array}{l}\text { FEDERAL } \\
\text { ACTIONS }\end{array}$ & $\begin{array}{l}\text { Implement all measures designated for Phase } 11 \mathrm{I} \text {. } \\
\text { Mandate electricity transmission between regions. } \\
\text { Temporarlly susdend clear air immlementation nlans }\end{array}$ \\
\hline & $\begin{array}{l}\text { ENERGY } \\
\text { EMERGENCY } \\
\text { CENTER AND } \\
\text { INFORMATION } \\
\text { SYSTENS }\end{array}$ & $\begin{array}{l}\text { Implement all functions of the EEC and institute special data collection } \\
\text { and monitoring procedures to respond to local shortage of electricity } \\
\text { (e.g., altering the criteria for submission of FrC form } 247 \mathrm{~A} \text { or } 2478 \text {. }\end{array}$ \\
\hline
\end{tabular}


During Phase II, federal measures would be 1 imited to implementation of the demand restraint program for federal facilities and encouragement of power wheeling wherever local shortages are not being adequately addressed. The EEC will be implemented only if justified by shortages of fuels. Exception reporting by utilities will be initiated to identify those utilities with extremely low inventories of coal and/ or resid.

- Phase III: Moderate Electricity and Coal Shortages.

When electricity and coal shortages are moderate, a number of relatively "high impact" measures will be implemented by federal and state governments and utilities. Many of the voluntary measures designated for Phase II may become mandatory and significantly affect patterns of residential and commercial consumption, For example, under the PJM Coordinated Program for Reduction in Energy Use classes of consumers are directed to reduce consumption relative to a base period by specific percentages; hours for commercial establishments must be reduced and window and display lighting eliminated; and heating and cooling standards are established. Also, procedures are implemented to reduce loss of electricity due to maintenance and operations schedules at utilities.

During Phase III, the Federal Government will consider implementing two measures. The implementation of each measure will depend on the specific circumstances associated with the shortage.

- DOE may reduce uranium enrichment activities at three gaseous diffusion plants in Ohio, Kentucky, and Tennessee, when shortages in that region are sufficiently severe to justify the relatively high cost of the measure.

- If electricity shortages are attributable to shortages of coal, DOE may authorize tempurary modifications to conversion orders which will permit the utilities to burn natural gas or petroleum products, when adequate supplies of those fuels are available.

\section{Phase IV: Severe Electricity and Coal Shortages.}

The measures to be implemented during severe electricity and coal shortages are basically the same as those designated for Phase III. However, terms of demand restraint measures wi il be made more stringent. Under some circumstances, using the authority of the Federal Puwer Act, mandatory electricity transfers between regions to respond to particularly severe local shortages that threaten high priority end users may be necessary.

Also, the Federal Government may take action permit suspension of the State Clean Air. Act Implementation Plans. Under the Clean Air Act amendments, the President can declare an emergency in a state or region which will authorize a governor to suspend the state implementation plan for clean air standards. This will permit some electric power plants to substitute coal for petroleum fuel during a petroleum shortage. 
In the event of a severe electricity shortage all EEC functions and emergency information systems related to electricity will be.implemented.

\subsubsection{Implementation Guidelines for Propane Shortages}

Based on the experience of the winter of 1976-77, and projections for the current winter, state and regional shortages are as likely to occur due to limited distribution capacity as to the unavailability of supplies in the aggregate. Therefore, the implementation guidelines for propane addresses shortages resulting from either set of circumstances.

During Phase I, prior to a propane shortage, relatively little action can be taken, except for encouraging maximum storage and clarifying the federal position on increased imports for this winter.

When there are mild aggregate propane shortages, further restrictions on the use of propane as an alternate fuel for uses such as boiler fuel or space heating may be instituted. However, if there are relatively severe localized shortages which cannot be adequately addressed by the transportation and energy industries, the ICC may implement the following emergency measures I!.

- Direct the movement of critical commodities

- Direct-railroads to give priority to the movement of fuel

- Establish transportation priorities

Finally, in the event of a moderate aggregate shortage of propane, or frequent severe local shortages, a special rule for the emergency allocation of propane to protect health, safety, and property may be promulagated. The ICC may request new legislation to direct the use of private railcars in the event of a severe shortage.

\subsubsection{Impact Assistance Measures}

There are nine significant measures which may be implemented during an energy shortage to offset severe economic effects on small businesses, and low income faililies and individuals. Several of the measures represent different approaches to the same problem. The measures 1 isted below already have enabling legislation. However, some may require modifications of existing regulations or reprogramming of federal funds.

- Assistance to low-income individuals and families for payment of bills

- Emergency food stamps to supplement need during an energy emergency

1) Transportation measures are relatively extreme, and therefore, will be implemented after all other approaches have failed to relieve affected localities. 
- Short-term public service employment

- Community Service Administration crisis intervention financial assistance, mediation with utilities and fuel dealers for the poor, elderly, and other needy

- Special assistance to the elderly

- Ban on the termination of utility services and non-deliveries for non-payment

- Sma11 Business Administration assistance for energy emergencies

- Expediting use of federal fuel supplies and transportation facilities by the public in emergencies

- Expediting unemployment compensation claims resulting from layoffs due to energy shortages. 


\subsection{Legal Authorities}

Most of the measures contained in this Guide are provided for by existing legal authorities. In some cases, however, new legal authorities for the more drastic measures would need to be enacted on an emergency basis. This section specifies which measures can be implemented with existing legal authorities and where new authorities are needed.

\subsubsection{Currently Authorized Measures}

The following specific measures do not require new legislative authority:

- Natural Gas

- Maximize interstate storage levels (NGA)

- Encourage increased natural gas imports (NGA)

- Implement special rule for ethane-propane mixtures as supplemental natural gas (EPAA)

- State-run exchange program (legal responsibility at State level)

- State-run intrastate redirection (legal responsibility at State level)

- Accelerate Federal lease production (EPCA)

- Reallocation of Federal royalty gas (OCS Act)

- Temporary sales of intrastate gas in interstate market (NGA)

- Electricity/Coal

- Power pool fuel sharing agreements (legal responsibility at State level)

- Uranium enrichment load shedding

- Mandatory electrical energy transfer, interchange or transmission (FPA)

- Modify coal conversion orders (ESECA)

- Suspend air quality standards (Clean Air Act Amendments of 1977) 
- Propane

- Clarify position on propane imports (EPAA as amended by EPCA)

- Fully implement existing restrictions on the use of propane as alternate fuel for "less essential uses" (EPAA as amended by EPCA)

- Develop new special rule to establish emergency method of allocation for propane (EPAA as amended by EPCA)

- Petroleum

- Encourage industrial storage (EPAA as amended by FP(A)

- Implement middle distillate state set-aside program (EPAA as amended by EPCA)

- Order refinery yield adjustments (EPAA as amended by EPCA)

- Equalize cost of imported petroleum products through entitlements (EPAA as amended by EPCA)

- Reimpose allocation controls on uncontrolled petroleum products (EPAA as amended by EPCA)

- Drawdown of Strategic Petroleum Reserves (EPCA)

- Transportation

. Suspend driver hours of service restrictions

- Defer vehicle inspection requirements

- Waive Jones Act

- Grant temporary authority to transport critical commodities

- Direct railroads to give priority to movements of fuel and other essential connodities

- Prohibit trains from entering impassable areas

- Obtain expanded emergency transportation priority and allocation authority 
- Assistance Plans

- Emergency fuel supply transfers from Federal stocks to civilian sector

- Short term public service employment (Comprehensive Employment Training Act)

- Small business assistance for energy related Impacts (Smal1 Business Act)

- CSA crisis intervention (Economic Opportunity Act) (appropriation required)

- Expedite unemployment compensation claims resulting from layoffs due to energy shortages

- Bans on termination of utilities

- Special energy assistance to the elderiy (01der American Act)

2.2.2. Measures requiring Federal legislation:

- Emergency assistance to low-income individuals for payment of fuel bills: HEW has sent legislation to Congress which would expand current emergency assistance in the following ways:

1. Extend the period of effectiveness from a maximum of 30 days to the duration of the actual state of emergency.

2. Extend eligibilty to adult individuals (both single and married) without children.

3. Increase federal participation.

- Obtain expanded ICC authority to include privately owned rail cars: This action requires amendment of the Interstate commerce Act to provide the ICC with temporary authority to direct rail cars owned by private manufacturers and thus not otherwise under the jurisdiction of the ICC. 
- Ban boiler fuel use of natural gas: During a severe energy supply interruption caused by an embargo on imported petroleum products, or sabotage or an act of God, this provision could possibly be implemented as an EPCA contingency plan. Otherwise specific legislation will be required, either in the enactment of the National Energy Act or by separate legislation.

- Allocate natural gas for high priority use: The authority contained in the Emergency Natural Gas Act (PL 95-2) has expired. Extension and expansion of this authority is contained in the National Energy Act.

\subsubsection{Current Federal Legislative Status}

The status of legislative initiatives as of the writing of this Guide (November, 1977) is as follows:

- Emergency Assistance:

Because the HEW emergency assistance revisions will not be enacted in time for the winter of 1977, a special appropriation will be required to continue the Community Services Administration special crisis intervention program (SCIP). An amnunt of $\$ 200$ million has been added for this purpose to HR 9375, the FY 1978 supplemental appropriations bill, which will be taken up by the House of Representatives in late November.

- Ban the boiler fuel use of natural gas:

The Sellale ver'sion of HR4018, the utility rate reform provisions of the National Energy Act, contains authority for temporary bans on the boiler fuel use of natural gas in the event. nf. a natural gas emergency as defined by the Emergency Natural Gas Act of 1977. There is no equivalent provision in the House-passed bill. The Conference Committee will take up this issue.

- Allocate natural gas for high priority use:

Both House and Senate versions of the natural gas provisions of the NEA contain authority to extend and expand the allocation provisions of the Emergency Natural Gas Act. The Conference Committee will take up this issue.

- Obtain expanded ICC authority to include privatoly owned rail cars:

There has been no legislative action on this issue. 


\subsection{Winter Energy Data Bulletin}

The Energy Information Administration within the Department of Energy will issue a Winter Energy Data Bulletin prior to and during the winter. The first issue (November 1) of the Bulletin is shown in Exhibit 2.3-1. The Bulletin will provide up-to-date information to help Federal, state and local officials identify potential energy shortage and take early corrective action. Information on fuel supply and demand, stocks of fuel in storage, and weather forecasts from the National Oceanic and Atmospheric Administration will be included.

Other data systems being used by the Department of Energy, related to winter emergencies, are described in Appendix 6 . 


\section{Winter

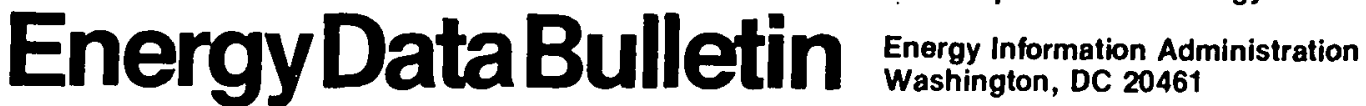

November 1, 1977

\section{FUEL SUPPLY FORECAST}

\section{Natural Gas Curtailments}

The May 1977 Natural Gas Curtailment Survey conducted jointly by the FEA and the FPC indicates that the Nation's natural gas distributors and pipolines arc projecting a total of 1.83 trillion cubic feet (tcf) of curtailments to end-use customers for the heating season (Novenber 1, 1977, through March 31, 1978). This is 7.8 percent lower than last heating season.

\section{Gas Storage}

Underground natural gas stoxage operators reported 2.6 tef in working storage on August 31,1977 . This amount is 81 percent of the developed capacity. The latest figures indicate the stored gas should reach 3.0 tcf, of 92 percent of capacity, by November 1, 1977. On November 1, 1976, 2.7 tcf were in storage.

Large intrastate operators estimate their facilities will reach 99 percent of capacity by November 1 . Large interstate operators anticinate reaching 93 percent of capacity. However, the small operators, having a storage capacity. of only 7 percent, mainly in the producing States, are not projecting such high levels of storage.

\section{Refined Product}

The Energy Information Administration estimates this winter's demand for residual,oil, distillate, and propane would be essentially unchanged over last year's actual demand of 8.7 million barrels per day - MMb/d (in addition to normal weather, these estimates are based upon major assumptions, including the following: no change in the historical trend of fuel substitution; no effects of disruption in coal production; and no substantial change from the current level of economic activity).

Last winter (October 1976-March 1977) was 14 percent colder than normal (30-year average) as measured by heating degree-days. Increased energy requirements fell most heavily on the petroleum products of residual Iuel oll, distillate, and propane.

Last winter's increment to demand due to cold weather for these three petroleum products together was about. 900,000 barrels per day, or about 12 percent greater than demand woula have been had normal weather been experienced $(8.72 \mathrm{Mmb} / \mathrm{d}$ vs. $7.82 \mathrm{MMb} / \mathrm{d})$.

If this winter is as cold as last winter, demand for these three products together may be as high as 9.35 MMb/d, or 7.4 percent more than projected for a normal winter.

At the end of September 1977, crude oil stocks were 354 million barrels, some 50 million barrels more than the same time last year.

\section{Coal}

The United Mine Workers of America's (UMW) contract with coal mine operators expires December: 6,1977 . Some tacts to bear in mind in the event of a coal strike are:

- UMW mines produce nearly 58 percent of the Nation's coal.

- Alnust two-thirds of that coal is mined east of the Mississippi.

- The eastern States are the heaviest coal consumers.

- All steel production is dependent upon coal.

- Coal is used to generate 46 percent of electric power in this country.

- Coal forms 15 percent of fuel requirements for manufacturers and industrials.

Current coal stock's insure a 30-day supply for industrial and steel plants.

- rurrent coal jtocks at liust electric ueilities insure a 3 -month supply.

\section{WEATHER SUMMARY}

The weather across the Nation during the period, October 17-23, 1977, moderated somewhat when compared with the first half of the month. Only the area east of the Mississippi River, excluding Maine, and the far west coastline from $S$ an Francisco northward to the U.S./Canada border experienced colder than normal weather. The accumulatel heating degree-days 1 from July lst, however, remain in excess of nomal 2 for the entire Nation with the exception of the southwest. Some detail of these acoumulated heating deyprop-inys can be reviewed in the table of selected large cities.

i/ A heating degree-day fo the number obtained by taking the average of the minimum and maximum temperature for the day and then subtracting that number from 65 .

2/ Normal degree-days are the average heating degreedays during the 1941-70 pertod. 


\section{Winter Energy Data Bulletin}
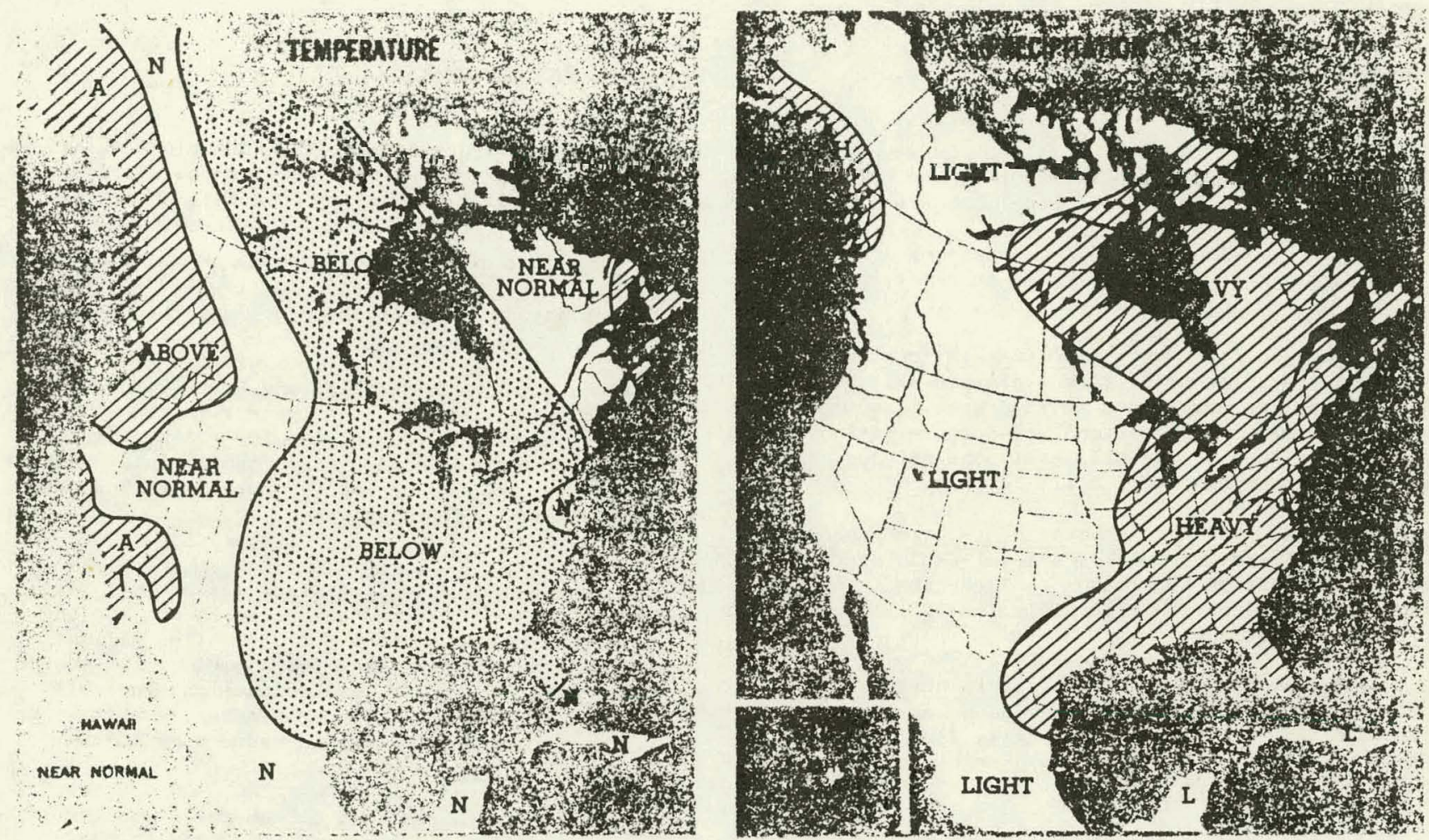

Source for data and maps: U.S. Department of Commerce, National Oceanic and Atmospheric Administration, National Weather Service.

Accumulated Heating Degree-Days $(7 / 1-10 / 23 / 77)$

\begin{tabular}{|c|c|c|c|c|c|}
\hline $\begin{array}{c}\text { City/DOE } \\
\text { Region } \\
\end{array}$ & Normal & 1976 & 1977 & $\begin{array}{l}\text { Above/Below } \\
\text { Normal }\end{array}$ & $\begin{array}{c}\text { Above/Below } \\
1976 \\
\end{array}$ \\
\hline $\begin{array}{c}\text { Washington } \\
\text { Region } 1\end{array}$ & 128 & 183 & 166 & +298 & -98 \\
\hline Doston & $28 \cap$ & 304 & 324 & +16 & +7 \\
\hline Hartford & 371 & 424 & 430 & +16 & +1 \\
\hline Portland, ME & 619 & 775 & 723 & +17 & -7 \\
\hline $\begin{array}{l}\text { Providence } \\
\text { Region } 2\end{array}$ & 333 & 460 & 399 & +20 & -14 \\
\hline Buffalo & 458 & 597 & 550 & +20 & -8 \\
\hline $\begin{array}{l}\text { New York } \\
\text { Region } 3\end{array}$ & 167 & 231 & 297 & +78 & +29 \\
\hline Philadelphia & 193 & 278 & 291 & +51 & +5 \\
\hline Pittsburgh & 371 & 608 & 517 & +39 & -15 \\
\hline $\begin{array}{l}\text { Rirhmond } \\
\text { Region } 4\end{array}$ & 147 & 217 & 231 & +57 & +6 \\
\hline Asheville & 221 & 345 & 306 & +38 & -11 \\
\hline Atlanta & 87 & 164 & 166 & +91 & +1 \\
\hline Birmingham & 86 & 144 & 173 & +101 & +20 \\
\hline Columbia, SC & 64 & 130 & 189 & +135 & +45 \\
\hline Jacksonville & 5 & 48 & 78 & -- & --- \\
\hline Miami & 0 & 0 & 0 & --- & --- \\
\hline $\begin{array}{l}\text { Memphis } \\
\text { Region } 5\end{array}$ & 89 & 122 & 122 & +37 & 0 \\
\hline Chicago & 261 & 430 & 382 & +46 & -13 \\
\hline Cincinnati & 211 & 381 & 372 & +46 & -2 \\
\hline Cleveland & 356 & 503 & 409 & +15 & -19 \\
\hline Detroit & 367 & 403 & 535 & +46 & +11 \\
\hline Minneapolis & 509 & 584 & 643 & +26 & +10 \\
\hline $\begin{array}{l}\text { Des Moines } \\
\text { Region } 6\end{array}$ & 324 & 413 & 360 & +11 & -13 \\
\hline Alberquerque & 129 & 237 & 121 & -6 & -49 \\
\hline
\end{tabular}

Accumulated Heating Degree-Days $(7 / 1-10 / 23 / 77)$

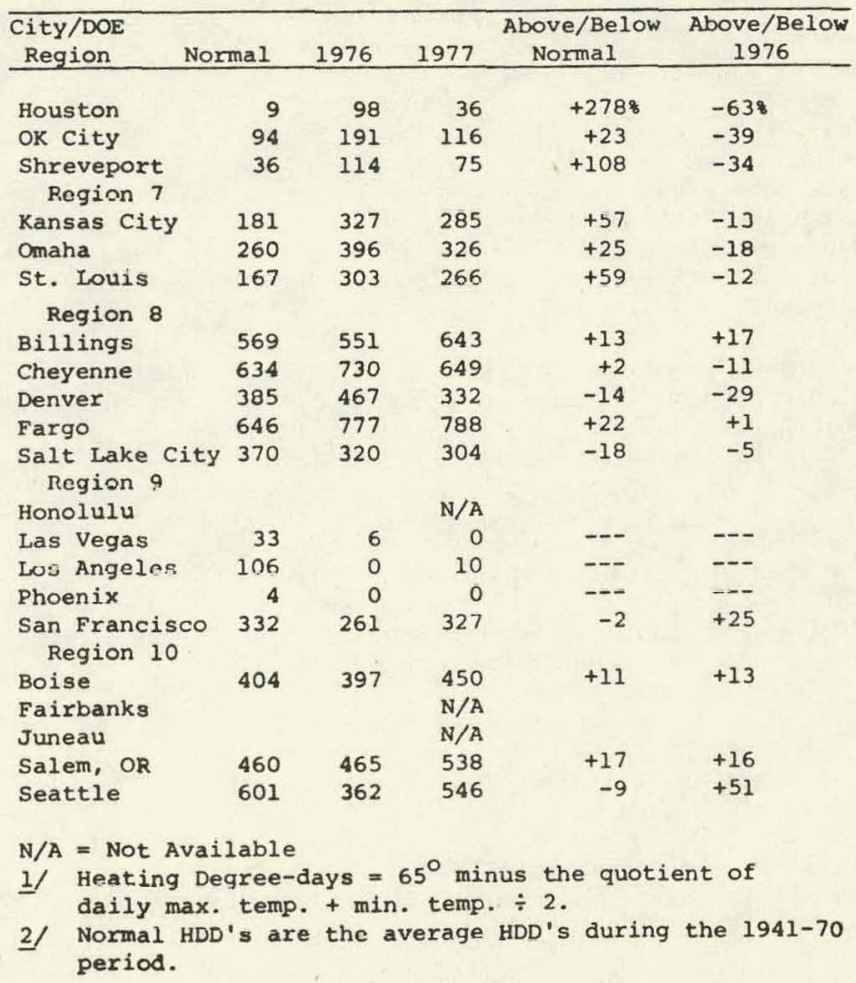


Exhibit 2.3-1 (Cont.)

\section{Winter Energy Data Bulletin}

\section{Natural Gas Curtailments}

The May 1977 Natural Gas Curtailment Survey conducted by the FEA and the FPC indicates that the Nation's natural gas distributors and pipelines are projecting the following:

- No curtailments of residential customers are projected for the $1977-78$ season.

- Projected curtailments of commercial customers are expected to decrease this winter in 29 states and increase or not change in 21 States, assuming normal winter weather and continued conservation practices. At the national level, the net decrease is 15 billion cubic feet, or 14 percent.

- Indintrial custuliess ' curtallments are expected to decrease from last winter's level in 29 states and to increase or not change in 21 states. The net decrease at the national level is 102 billion cubic feet, or 11 percent.

Projected curtailments of electric utility customers for the 1977-78 heating season (assuming normal winter weather) will decrease 33 billion cubic feet, or 4 percent, from last winter's reported curtailments.

Reporting companies indicate that conservation and switching to other fuels (such as coal and oil) hy large induslılal and electric utility customers have reduced projected requirements for gas.

\section{3}

\section{Petroleum Products}

According to analyses made by the Economic Regulatory Administration, supplies of alternate fuels appear adequate to satisfy the needs of curtailed natural gas customers as well as normal fuel requirements.

- Propane demands due to gas curtailments (assuming a normal winter) are projected for the 1977-78 heating season at the national level to be less than last winter.

- However hoth North Carolina and South Carolina are susceptible to shortages of propane cven assuming normal winter weather during the 1977-78 heating season. Ten percent colder than normal winter weather could also bring propane supply problems to Tennessee. Kentucky, unio, and Pennsylvania.

- The amount of Middle distillate (light fuel oil) necded to offset projected gas curtailmonts for the 1977-78 heating season is about 80 million gallons lower than last winter, assuming normal winter weather No problems at the state level with light fuel oil supplies are expected if winter weather is normal, but 10 percent colder weather could cause some local problems in Montana.

- No problems with residual oil at the state level are projected for this coming winter even if the weather is 10 percent colder than normal. 
DOE DEMAND WATCH

Domestic demand for all petroleum products for the 4 weeks ending 0ctober 14, 1977 , averaged 18.0 million barrels per day, 6.0 percent above the same period in 1976 . Demand was 11.4 percent above the 1975 level and 5.6 percent above the level in 1973, just at the start of the embargo.

Motor gasoline demand was 2.3 percent above last year, 6.1 percent above the 1975 level, and 7.9 percent above the 1973 level.

Residual fuel oil demand was up 15.7 percent from the 1976 level, 26.1 percent above 1975, and 11.0 percent above 1973. Demand for dist111ate was up 7.6 percent from the the 1976 level, 23.7 percent above 1975, and 7.0 percent above 1973 .

Imports for the 4-week perlod averaged 8.9 million barrels per day, 15.4 percent above the 1976 level, 36.2 percent above 1975, and 35.8 percent above 1973 . Crude o11 imports were 85.9 percent higher than 1973 with product 1mports down 26.9 percent from 1973 .

DEMAND FOR PETROLEUM PRODUCTS

(Thousands of barrels per day)

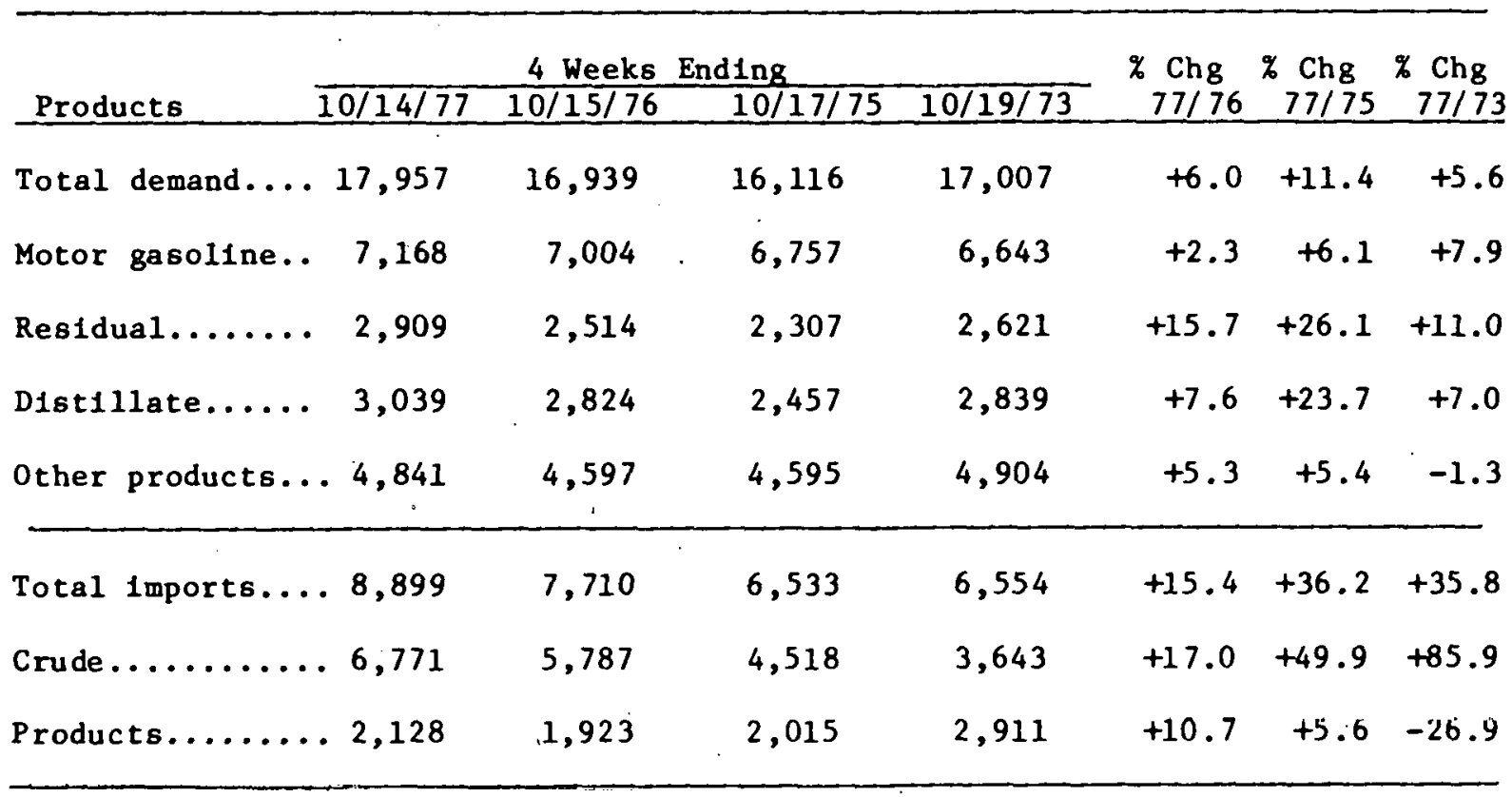

Note: DOE defines "demand" as "disappearance from primary supply." This is output from refineries plus net imports (imports minus exports) plus or minus changes in primary stocks. Primary stocks include storage facilities over 50,000 barrels. DOE demand calculations for 1977 are based on weekly data from API, which are later validated by comparison with DOE monthly data. Imports for 1977 are from API. Data for previous years are based on interpolations of Bureau of Mines' data. 


\subsection{Energy Emergency Center}

An Energy Emergency Center (EEC) will be established by the Department of Energy to serve as a focal point for coordination of energy emergency efforts and for communications between Federal, state and local governments. The Center, to be set up at $2000 \mathrm{M}$ Street, NW., in Washington, D.C., will be operational by December 1, 1977. A detailed description of the functions and implementation plans for the Center is provided in Appendix 7. 


\subsection{ENERGY EMERGENCY MEASURES}

\subsection{Sumimary}

This section reports the government actions which may be employed to deal with an energy emergency. Possible measures to deal with emergencies in each energy resource are presented, followed by transportation, materials allocation, and impact assistance programs.

While this section lists a large number of potential measures, development priority is being given to those measures considered most likely to be needed this winter. These are the natural gas, propane and assistance measures, 1 isted in Sections $3.2,3.4$, and 3.9 .

Frequently a shortage in one energy resource is offset by industry action to substitute a different energy resource or obtain additional resources from alternate sources (i.e., imports). When industry action is constrained by physical or legal limitations, government actions may be necessary to ensure adequate energy for health and vital services and maintenance of economic activity. The measures cover natural gas, electricity, including fuel switching, petrolleum, and propane as well as energy transportation and materials allocation for production and distribution of energy.

Finally, measures are proposed to reduce demand and provide assistance to persons adversely affected by the energy emergency.

Implementing documentation for each measure will be provided. The documentation will consist of interagency memoranda of understanding, draft legislative initiatives, outlines of regulations required for each measure, and other supporting materials. It is provided in this document wherever practical.

Measures are quantified in terms of their benefit and cost. Benefit is measured as the effect of the action fully implemented without compensation for alternate fuels. The costs are a calculation of the implementation costs and the incremental cost to the consumer or industry.

\subsection{Natural Gas Measures}

Projected natural gas curtailments of end-use customer requirements during the heating season November 1977 - March 1978 are shown in Exhibit 3.2.1. These curtailments are projected to be 13.9 percent of end-use customer requirements. The total of 1.8 trillion cubic feet curtailment represents an average of 366 billion cubic feet per month (bcf/mo). It is rccognized that the absolute curtailment. is probably overstated and that the monthly curtailment during the heating season will not be uniform. In addition, 63 percent of the curtailment is to interruptible customers. 1 The remaining $135.4 \mathrm{bcf} / \mathrm{mo}$, while technically

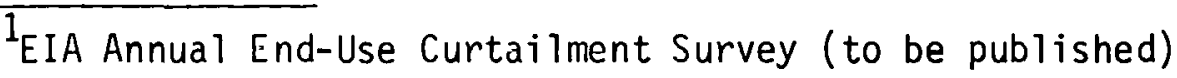




\section{Exhibit 3.2 .1 \\ I \\ END-USE CUSTOMER NATURAL GAS STATUS}

(Trillions of Cubic Feet)

Actual (November 1976-March 1977)

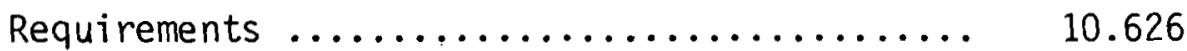

Deliveries ............................. 8.640

Curtailments ......................... 1.986

Percent curtailed $\ldots \ldots \ldots \ldots \ldots \ldots \ldots \ldots . \ldots \ldots$

Projected (Novcmber 1977-March 1978)

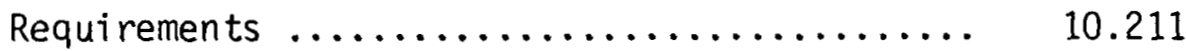

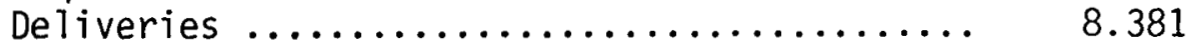

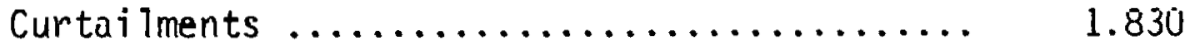

Percent curtailed ................. $17.9 \%$

Source: Energy Information Administration 
identified as firm requirements, includes a large number of customers that have alternate fuel capability. There is no evidence to indicate that curtailments to residential and small commercial customers (Priority 1) will occur this winter.

In order to be prepared to respond to a natural gas shortage three types of measures are analyzed. Supply increase and demand restraint measures directly address the problem by providing gas to alleviate the shortfall. Supply distribution measures, on the other hand, shift the available supply around to ensure that priority users have adequate natural gas and help alleviate acute regional shortages.

As shown in Exhibit 3.2.2, if all supply increase measures were employed, they would provide, by conservative estimate, about 32.1 $\mathrm{Bcf} / \mathrm{mo}$. This is 24 percent of the average monthly curtailment to enduse firm requirements. If all demand restraint measures were mandated, they would reduce the end-use firm requirement by $53 \mathrm{Bcf} / \mathrm{mo}$., or 39 percent. Use of all the supply increase and demand restraint measures would reduce curtailment by about $95 \mathrm{Bcf} / \mathrm{mo}$. or 53 percent.

It is unlikely, however, that all measures could, or would, be employed simultaneously. Moreover, resdistribution of available supply would help to alleviate hardship without either increasing supply or reducing demand. Thus, the above percentages and their sum are not useful measures of the impact of the proposals. As is pointed out in the strategy section, additional considerations, along with the magnitude of shortage, will be used to determine what measures are employed.

Furthermore, several of these measures require completion of legislation action (i.e., boiler fuel prohibition, ornamental gas lighting ban, and extension of allocation under Section 4 of ENGA) so that their use depends on the outcome and timing of Congressional action, and subsequent promulgation of regulations.

Other measures, such as reallocation of royalty gas from federal leases, preemption of producer-reserved OCS gas, and mandatory increases in production from federal leases, require the adoption of. new regulations under existing authorities. As in other parts of this plan, voluntary actions taken by the natural gas industry and its customers are regarded as preferrable to the imposition of mandatory measures.

In addition to the special measures described in this section, the Federal Energy Regulatory Commission routinely takes actions under the Natural Gas Act in anticipation of shortages of natural gas supplies. These actions include monitoring, encouragement and approval of short-term emergency supplies, transportation, and exchanges between and among producers, distributors and intrastate pipeline companies. 
Exhibit 3.2 .2

COST/BENEFIT OF NATURAL GAS MEASURES

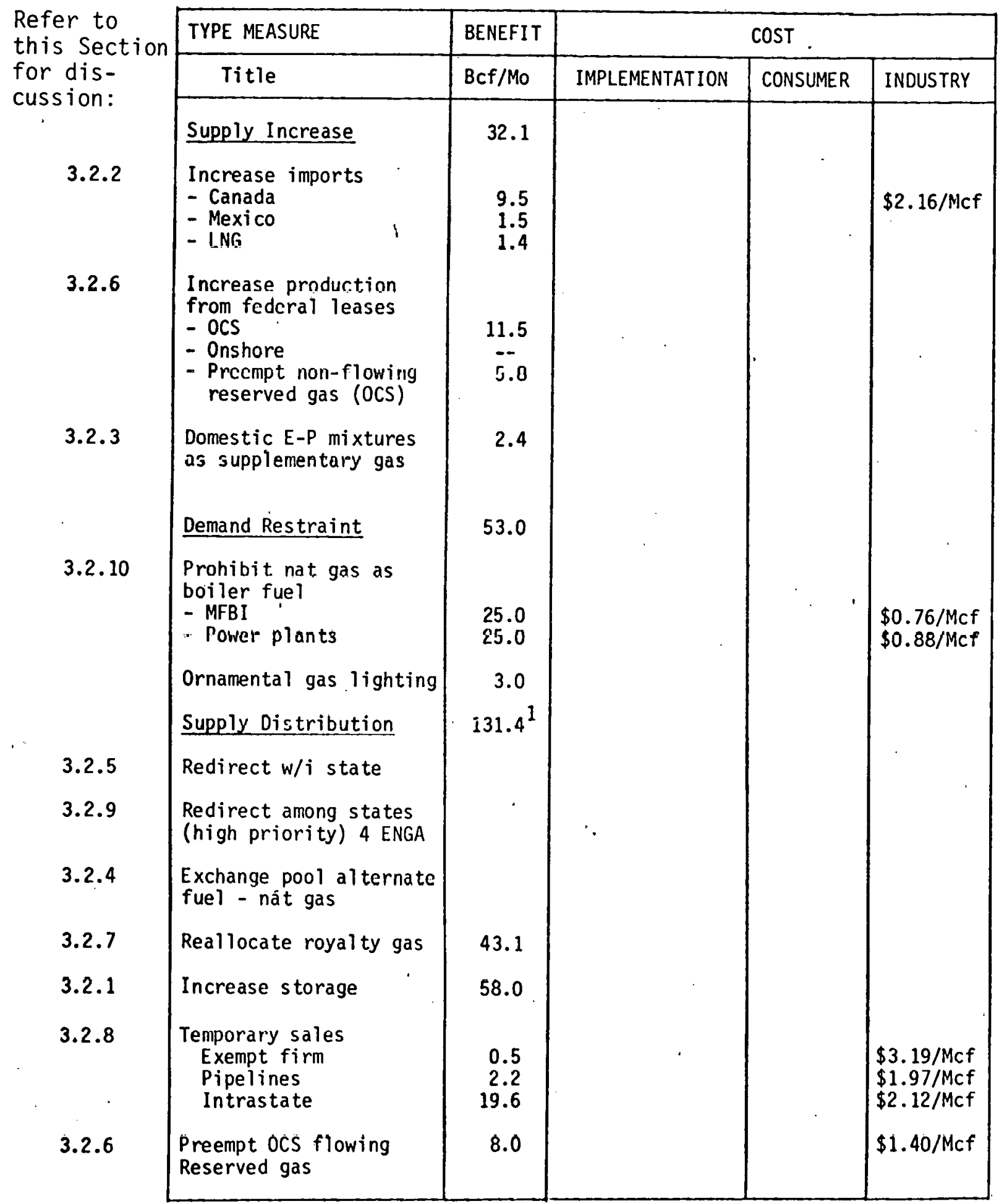

1/Available for redistribution, not considered additional supply. 


\subsubsection{Maxmimize Storage Levels}

\subsubsection{Objective}

Ensure that the storage of natural gas is maximized prior to the beginning of the heating season.

\subsubsection{Concept of Operations}

On a monthly cycle between April and November and biweekly during the heating season, each interstate pipeline reports storage levels to FERC, and large distribution companies and intrastate pipelines report storage levels to EIA. These reports for September 30, 1977, are summarized in Exhibit 3.2.3.

Formal hearings or rulemaking proceedings are required to mandate changes in storage operations of interstate pipelines. There is no federal authority to allocate underground storage supplies between pipelines.

State Regulatory Commissions will be advised of apparent low storage situations within their jurisdiction for appropriate action.

\subsubsection{Benefits and Cost}

Based on recent projections of total underground storage (both interstate and intrastate), 290 Bcf more gas will be in storage on November 1, 1977, than was available last year on the same date. This represents $58.0 \mathrm{Bcf} / \mathrm{mo}$ for withdrawl during the heating season by interstate and intrastate pipelines and local distribution companies. 
3.2.1.4 Startup Plan

Actions Taken

Obtain natural gas

storage reports

Determine opportunities

to effect increased storage

Actions Remaining

Conduct hearings

Order increased fill rates
Agency

FEA/FPC

DOE

October 20
Completion Date

September 29

FERC

FERC as needed

as needed

\subsubsection{Special Requirements and Documentation}

storage injections.

lletermination of st.at.e authorit.y t.o order

EXHIBIT 3.2.3 National Summary of Working Gas in Underground Storage

EXHIBIT 3.2.4 Level of Fill by Operator, Working Natural Gas in Underground Storage 
WORKING GAS N UNDERGROUND STORAGE TOTAL ALL CPERATORS

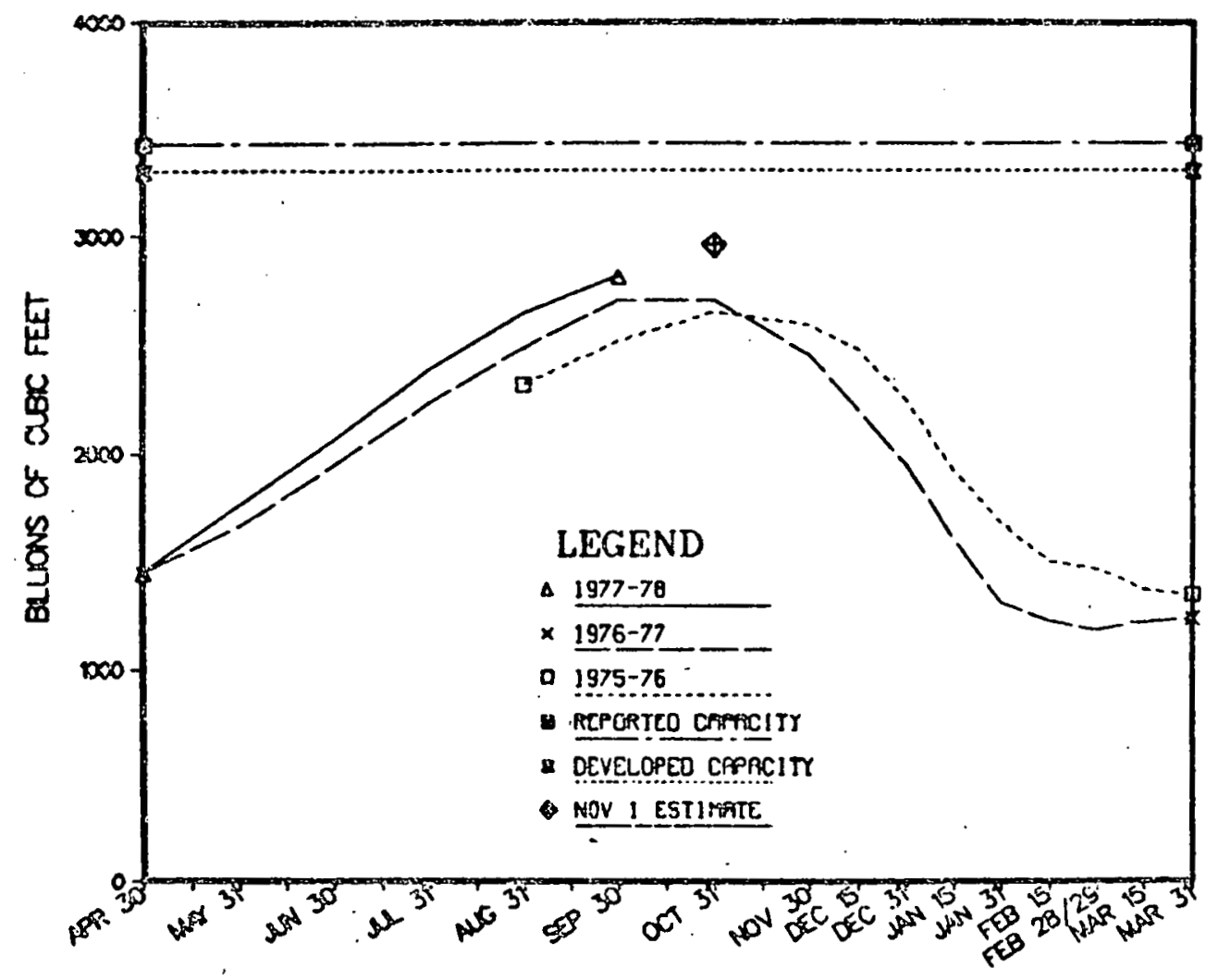

WORK ING GAS IN UNDERGROUND STORAGE

\begin{tabular}{|c|c|c|c|c|}
\hline $1975-76$ & $1976-77$ & $\begin{array}{l}\text { Percent } \\
\text { Change }\end{array}$ & $1977-78$ & $\begin{array}{l}\text { Yercent } \\
\text { Change }\end{array}$ \\
\hline
\end{tabular}

$\begin{array}{lrrr}\text { Apr 30 } & & 1,443 & \\ \text { May 31 } & & 1,664 & \\ \text { Jun 30 } & & 1,943 & \\ \text { Jul 31 } & & 2,232 & \\ \text { Aug 31 } & \text { R 2,317 } & 2,487 & 9.0 \\ \text { Sep 30 } & \text { R } 2,511 & 2,704 & 9.3 \\ \text { Oct 31 } & \text { R } 2,648 & 2,703 & 2.3 \\ \text { Nnv 30 } & \text { R } 2,588 & 2,450 & -5.3 \\ \text { Dec 15 } & 2,477 & 2,200 & -11.2 \\ \text { Dec 31 } & 2,249 & 1,950 & -13.3 \\ \text { Jan 15 } & 1,918 & 1,606 & -16.3 \\ \text { Jan 31 } & 1,674 & 1,304 & -22.1 \\ \text { Feb 15 } & 1,498 & 1,224 & -18.3 \\ \text { Feb 28/29 } & 1,463 & 1,183 & -19.1 \\ \text { Mar 15 } & 1,369 & 1,218 & -11.0 \\ \text { Mar 31 } & \mathrm{R} 1,343 & 1,234 & -8.5\end{array}$

No. Operators:

No. States:

No. Ticservoiret

Total Reservoir Capacity:

Base Gas $(8-31-77)$ :

working Gas Capacity:

Developed Capacity

Nov. I Estimate

$\begin{array}{ll}1,444 & 0.1 \\ 1,757 & 5.6 \\ 2,062 & 6.1 \\ 2,386 & 6.9 \\ 2,644 & 6.3 \\ 2,812 & 4.0\end{array}$

$R=$ Revised to reflect late filings and company revisions.

"Estimated currently developer capacity," fiqure and "Estimated Nov. I volume" figures are based on data collected by a telephone survey of 25 Interstate and 14 Intrastate Operacurs that store over $10 \mathrm{Bcf}$ of working gas. 


\section{EXHIBIT 3.2 .4}

Level of Fill by Operasor Working Natural Gas in Jnderground Storage as of 9/30/77*

(Thousands of Cubic Feat)

Storage Operator

Consolidated Gas Supjly Corp

Columbia Gas Transmission Corp

Natural Gas Pipeline Company of America

Michigan Wiscons in Pipeline Company

Michigan Consolidated Gas Company

Northern Illinois Ga; Company

Montana Dakota Utilities Company

Southern California Gas Company

Consumers Power Company

National Fuel Gas Supply Company

Transcontinental Gas Pipeline Compan.

Texas Gas Transmission Corporation

Cities Service Gas Company

Houston Pipeline Company

Kansas Nebraska Natural Gas Company

Pacific Gas and Electric Company

Lone Star Gas Company

East Ohio Gas Company

Northern Natural Gas Company

Southern Natural Gas Company

Michigan Gas Storage Company

United Gas Pipeline Company.

Peoples Gas and Light Company

Ok lahoma Natural Gas Company

Panhandle Eastern Pifeline Company

Mississippi River Transmission Corp

Northern Gas Company

Montana Power Company

Colorado Interstate Cas Company

Equitable Gas Company

Louisville Gas and Electric Company

Exxon Corporation

Washington Natural Gas Company

Texas Eastern Transmission Company

Illinois Power Company

The Peoples Natural Gas Company

E) Paso Natural Gas Company

Central Illinois Light Company

* Montana Fuel Resources

* Revised

* New Operator with over

10 Bcf working gas
Working Gas

Capacity

$\star 304,423,000$

$\star 304,423,000$
$\star 269,745,097$

$151,302,466$

$149,700,000$

$\star 122,339,816$

$148,942,413$

$125,738,884$

$125,170,000$

* 69,632,900

$\star 88,921,756$

$81,767,477$

$78,273,180$

$77,831,000$

$72,290,349$

$\star 62,269,820$

* $62,608,184$

$60,295,000$

* 54,440,000

$52,000,000$

$46,000,000$

$45,574,000$

$41,439,400$

$40,289,970$

$39,932,367$

$37,158,414$

$36,880,000$

$35,320,000$

$\star 33,839,417$

$27,580,282$

$\star 14,825,350$

$\star 35,405,225$

$\star \quad 16,600,000$

$15,300,537$

$12,482,332$

$11,758,999$

$11,266,000$

$11,066,529$

$102,875,000$

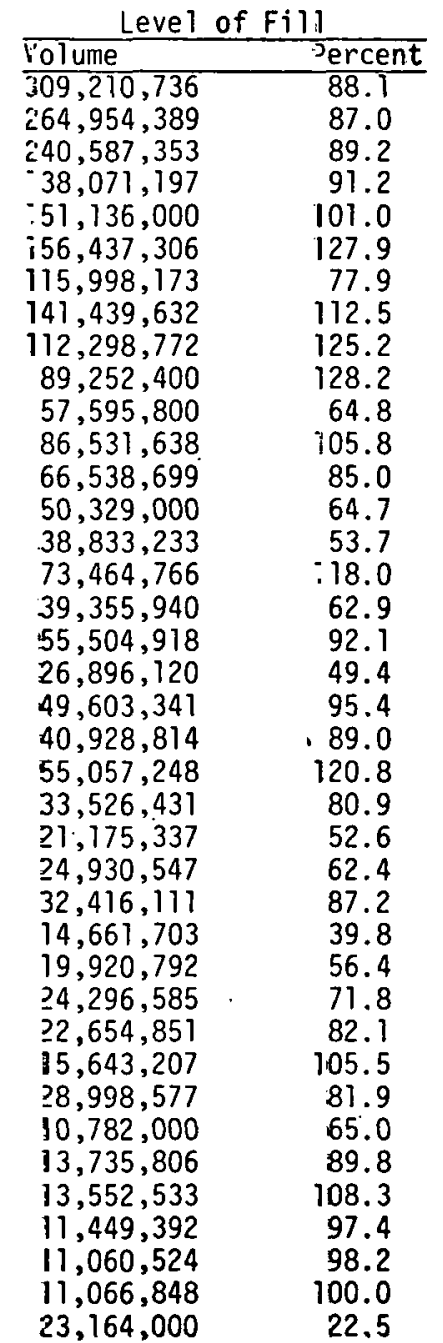

Service Area

$O H, P A, M D, K Y, N J, M Y, V A, W Y$

$A R, I L, I A, K S, M O, N B, O K$

IL , IA , MI , IN , KS , MO ,WI , KY ,LA , MS , OH ,TN ,TX ,OK

$\mathrm{MI}$

MN ,MT ,ND ,WY ,SD

$C A$

MI

NY , $P A, O H$

$A L, G A, L A, M D$; MS , NJ , NY , NC , PA , SC , VA ,TX

$A R, I L, I N, K Y, L A, M S, O H, T N, T X$

$\mathrm{KS}, \mathrm{MO}, \mathrm{NB}, \mathrm{OK}, \mathrm{TX}$

TX

$\mathrm{CO}, \mathrm{KS}, \mathrm{NB}, \mathrm{OK}, \mathrm{WY}$

$\mathrm{CA}$
$O K, T X$

$\mathrm{OH}$

$O K, S D, T X, W I, M I, I L, I A, K S, M O, C O, M N, N B, M T, N M$ $\mathrm{AL}, \mathrm{GA}, \mathrm{LA}, \mathrm{MS}, \mathrm{SC}, \mathrm{TX}$

$A L, F L, L A, M S, T X$

IL

CO,IL, IN ,KS , TX, MI ,WY ,MO,OH

$I L, M O, A R, L A$

WY

$\mathrm{CO}, \mathrm{KS}, \mathrm{NM}, \mathrm{WY}$

$K Y, P A, W V$

KY, $\mathrm{KA}$

TX

WA

$O H, P A, T N, T X, M D, M S, A L, A R, I L, I N, K Y, L A, M O, N J, N Y$

IL

$A Z, C O, N M, O K, T X$

IL

$\mathrm{CO}, \mathrm{UT}$

NOTE: Working Gas Capacity is the Total Reservoir Capacity, as reported ty the operator,

minus base gas as of 9/30/77. Current developed capacity, i.e., usable capacity

may be above or below this figure. 


\subsubsection{Encourage Increased Imports}

\subsubsection{Objective}

Ensure that natural gas and liquefied natural gas (LNG) imports are increased to maximum feasible levels.

\subsubsection{Concept of Operations}

DOE's Office of International Affairs (IA) monitors negotiations between exporting countries and U.S. importers and coordinates and encourages maximum imports consistent with national energy policy. Provided an emergency is declared by U.S. Federal or state government, the Canadian National Energy Board (NEB) Act empowers the NEB to act immediately without reference to minister or cabinet on request for emergency supply. NEB informs minister after granting emergency export permit. ERA approves certificates for importation as required. Additional negotiations will be required to determine details of delivery and compensation arrangements.

\subsubsection{Benefits and Cost}

Based on informal contacts, there could be sufficient additional supplies and available pipeline capacity to increase natural gas imports from Canada by up to $9.5 \mathrm{Bcf} / \mathrm{mo}$. FERC indicates that Mexican imports may be increased as much as $1.5 \mathrm{Bcf} / \mathrm{mo}$ over last year. In addition, up to $1.0 \mathrm{Bcf} / \mathrm{mo}$ may be available from Mexico later in the winter. Importation of additional LNG is constrained by long-term contractural arrangements, but an additional 7-9 Bcf (1.4-1.8 Bcf/mo) may be available from Indonesia. Landed cost of additional Canadian natural gas is currently $\$ 2.16$ per Mcf; and LNG ranges up to $\$ 3.88$ per Mcf.

\subsubsection{Startup Plan}

Actions Taken

Identify foreign supply sources

Actions Remaining

Detailed negotiations

Issue certificates
Agency

FEA
Completion Date

September 1
Pipeline/ERA

ERA/FERC as required

as required 


\subsubsection{Implement Special Rule for Domestic Ethane-Propane} Mixtures as Supplemental Natural Gas

\subsubsection{Objective}

Utilize excess inventories of domestic

Ethane-Propane mixtures to increase natural gas supplies to protect high priority users under adverse winter conditions.

\subsubsection{Concept of Operations}

The Economic Regulatory Administration may issue as an emergency measure, a regulation easing use limitations to permit the sale of ethane-propane (E-P) mixtures greater than 10 percent propane to distribution companies able to utilize such mixtures. Ethane and E-P mixtures have historically been used as petrochemical feedstocks. Due to reduced demand, excess $t-\mu$ mix inventories are accumulating which, to some extent, could be used as supplemental natural gas. The Bureau of Mines (BOM) reports ethane stocks for the last three years have grown as follows:

$\underline{\text { Date }}$

December 31,1974

December 31,1975

December 31,1976
Stocks* millions of barrels

*Source: BOM Mineral Fuels Survey

\subsubsection{Benefits and Cost}

Three million barrels of E-P mix have the BTU equivalent of $12 \mathrm{Bcf}$ of natural gas or $2.4 \mathrm{Bcf}$ per month over the heating season. The cost of 30 percent propane E-P mix is estimated to be $\$ 8.65$ per barre1. Transnortation and other costs of using it in PropaneAir plants must be added.

\subsubsection{Startup Plan}

Actions Taken

Research issue

Actions Remaining

Develop procedures

Issue rulemaking

Receive and approve applications
Agency

FEA 


\subsubsection{State-Run Exchange Program}

\subsubsection{Objective}

Establish a program in each natural gas consuming state which provides for maximum use of alternate fuels during periods of FERC Priority 3 curtailments.

\subsubsection{Concept of Operations}

The Department of Commerce will encourage states to authorize and sponsor an exchange pool program between firms which are dual-fired and other natural gas consumers. The basis for the program is successful programs in Kentucky and New York. See Exhibit 3.2.5 for a summary of these two plans. Transactions under these plans are exempt from FERC regulations for up to 60 days under Section 2.68. Notices of commencement and termination must be filed with the FERC by either the seller or transmission company.

\subsubsection{Benefits and Cost}

The primary benefit of these plans is the reduction of plant closings and unemployment caused by natural gas curtailments. The cost is directly affected by the level of curtailments, the total volume of natural gas, and the cost of alternate fuels. In the Kentucky plan, the additional cost is borne by the recipient industry. In the New York plan, the cost is rolled in to the natural gas price of all customers served by the utility.

\subsubsection{Startup Plan}

Actions Taken

Distribute Kentucky and New York plans

Actions Remaining

Authorize plan

Inform FERC of sales under plan
Agency

DOC
Completion Date

September 1
States

Seller or transporter
December 1

as required

\subsubsection{Special Requirements and Documentation} PUC authorization by each state. (As needed)

Exhibit 3.2.5 Summary of Intrastate Natural Gas/Alternate Fuel Exchange Pool Plans. 
Exhibit 3.2 .5

Summary of

Intiastate Natural Gas/Alternate

Fuel Exchange Pool Plans

\section{Background:}

Frequently, commercial and industrial natural gas users have alternate fuel capability and are not curtailed due to priority, or they have alternate fuel capability beyond current curtailments. Other industrial firms are curtailed to the point of lay offs.

During the past two years, the state of Kentucky and New York developed plans to minimize industrial plant closings due to natural gas curtailment. The plans proposed that industrial customers who had standby alternate fuel facilities exchange their natural gas allocations with cuscomers who had no alternate fuel facilities and were threatened with gas cutoff. The plans also included payback of the price differential between the alternate fuels and natural gas from the recipients of the gas to the customers who could burn alternate fuels.

The Kentucky Plan:

The Kentucky Plan was initiated in December of 1974 by Executive Order of the governor of Kentucky. The plan involves voluntary curtailment of customers with alternate fuel capability while the volume of gas released is made available on a pro rata basis to customers who are under natural gas curtailment and have no alternate fuel capability. Customers who receive the additional volume of natural gas must contribute financially to offset the additinnal cost of alternate fucls incurred by customers who make the additional gas available. The availability of natural gas released in this plan is contingent on securing required alternate fuel supply.

The Kentucky Plan worked well during the winters of 1974/1975 and 1975/ 1976. The plan did not work last winter because natural gas curtailments were too deep and adequate supply of alternate fuels was not available due to the freeze-up of the Mississippi and Ohio rivers.

The New York Plan:

The New York Plan was initialed by the State Public Service Commission, to encourage the installation of alternate fuel facilities. The plan provides for reimbursement of the cost difference between alternate fuel and natural gas between donors and recipients of natural gas. The New York Plan is mandatory and the higher cost for alternate fuels are passed on to all customers who are served by a distribution company on a pro rata basis. 
This plan worked well in New York State last winter, and it will be used again in this coming winter season.

Comparisons of the Two Plans:

Both plans have the same overall objective of releasing additional supplies of natural gas to industrial customers during curtailment by getting industrial or large commercial customers who have dual fuel installations to switch over. Both plans provide for reimbursement of the additional alternate fuel costs to the customers who switch over from natural gas.

The Kentucky Plan in VOLUNTARY, but the New York Plan is MANDATORY. The reimbursement of alternate fuel cost in Kentucky is handled by the state. In New York, the exchange of funds is handled by local gas utilities.

Both plans will work depending upon the severity of natural gas curtailment and the availability of alternate fuel supply.

Recommendations:

In an effort to reduce the impact of industrial unemployment related to natural gas shortages, it is recommended that governors, state energy offices, and state public utility commissions consider implementation of either of these plans for this coming winter.

Further detail information on the Kentucky Plan can be obtained from:

Mr. Gregory T. Guess

Kentucky Department of Energy

Capital Plaza Tower

Frankfort, Kentucky 40606

Telephone: ,502/564-7416

Further detail information on the New York Plan can be obtained from:

Mr. Joel BTau

State of New York

Public Service Commission

Department of Public Service

Empire State Plaza

Albany, New York 12223

Telephone: $518 / 474-1388$ 


\subsubsection{State-Run Intrastate Redirection}

\subsubsection{Objective}

Insure that state priorities are applied to

the distribution of natural gas flowing into the state during emergency periods.

\subsubsection{Concept of Operations}

The governor or appropriate state official would equalize or shift curtailments within the state according to state priorities rather than accept previous contractual arrangements. The authority to allocate to avoid high priority curtailment could not be delegated by the Federal Government wi thout an amendment to the Emergency Natural Gas Act (ENGA) of 1977. Section 2.68 of FERC Rules of Practice and Procedure (see Exhibit 3.2.6) provides that these actions do not require prior approval for up to 60 days. Either the seller or the transmission company must. inform FERC within 10 days of commencing and upon termination of a transaction.

\subsubsection{Benefit and Cost}

The benefit of these actions is the assurance that state end-users are provided natural gas based on state priorities. The costs are minimal.

\subsubsection{Startup Plan}

Actions Remaining

Letter to states advising of procedure

Publish in guidebook FERC Rule 2.68. Examples: Notice of commencement Notice of termination

Press release calling attention to procedure
Agency

DOE

DOE/DOC

DOE
Completion Date

Nuvember 15

December 1

December 1

3.2.5.5 Special Requirements and Documentation

Exhibit 3.2.6 -- FERC Rule 2.68 
Exhibit 3.2 .6

FPC Rule 2.68

\$2.68 Policy with respect to temporary emergency sales and deliveries of nat. ural gas for resale in interstate com. metce by persons with exemptions ander the Natural Gas Act pursuant to section $\mathrm{I}(\mathrm{c})$, and certain persons exempt under the Natural Cas Act pursuant to section 1 (b):

(a) Wlth respect to persons exempt from the provislons of the Natural Gas Act pursuant to section I(c) and distribution companles and Intrastate pipeunes only, exempt from the provislons of the Natural Gas Act pursuant to section $1(b)$, it will be the general policy of the Commlssion to encourage such persons and companies. If requested, to ald natural gas distribution companles and plpeline companles in need of temporarg emergency gas supplles, by making shortterm sales or dellvertes of natural gas in interstate commerce for perlods up to and Including 60 consecutive days without any express authorlzation by the Federal Power Commlssion: Proolded, That the seller (the exempt company) or transporter (a Jurlsaictional natural gas compang) eles with the Commlssion, in Docket No. R-388, withln 10 days after the emerzency commences, a statement in witing and under oath. together with four (4) conformed coples thereof, brlefls outlining the nature of the emergencs. Withln 10 days after the termination of the emergencs, a further sworn statement, and four (4) contormed coples thereof, shall be flled setting lorth the volume of $\mathrm{gas}$ delivered and indlcating (1) the total relmbursement recelyed by the seller and (2) the appllcabie rate schedule, if any, or, altermativeis, the hases by whlch the per Mct relmbursement was derived. A transporler should, of course, recelve adequate compensstian for eng additional transportation serpices rendered in connection. With its participation.la the dellvers of the emergency volumes of gas and, upon termnation of the emergency, shall inform the Commisslon, In writing, of the total amount of compensation recelved, if ans. and the means by which the per sicl compensation was derlved.

(b) If the emergency responded to is expected to have a duratlon longer than 60 consecutive days, the seller or the transporter shall oistain an advance statement from the Commission, prlor to termination of the 60-day perjod. that the seller's status under section $I$ (b) or (c) of the Act will not be affected as a result of the contemplated cmergency sales or dellverles, as the clrcumstances or such sales are desaribed in a written petition flled pursuant to 85.7 of the Commlssion's rules of practice and pro. cedure in this chapter to be addressed to the Commlssion. Sald petltion shail also set forth (1) the volumes of gas antlclpated to be delivered durlng (1) the irittal 60-day pertod and (II) during the perfod of extension,: and (2) the total entlclpated compensation or relmbursement to be recelved, if any, and the bases by whlch such per Mcl prlce was derlved. Within 10 dass after the terniniation of the emergency, as extended, the seller or transporter shall comply with all the requirements of the Instrat pollcy statement. as amended.

(Becs. 1(b), I(c), 7(c), 16, B3 Equt. 831, 820, $58^{\prime}$ Stst $23 ; 63$ 8ist. 38 ; 15 v.8.C. 717(t) $717(c), 717 f(c)$ ) (Orcier 202-A, 35 F.R. 8328, June 10, 1970, hs amended by Order $10 x-D$. 39 FR 8332, AI8T. E, 19741 


\title{
3.2.6 Accelerate Federal Lease Production
}

\author{
3.2.6.1 Objective \\ Maximize production of natural gas from leases \\ on federal lands during an emergency.
}

\subsubsection{Concept of Operations}

This measure has two components, orders to producers to increase production rates and a preemption of gas reserved for producers. DOI has not established maximum efficient rates (MER) or temporary emergency production rates (TEPR) as authorized in Section 106 of EPCA of 1975. Information on operator production by month has been obtained from DOI. On lanuary 25, 1977, thc Secretary of Intiriur requested dll OCS operators in the Gulf of Mexico to increase gas production and suspended the requirements of OCS Order No. 111 imiting production to the MER established for each lease. FERC has certified some production to be reserved for use by the producer. During the periods of high demand, some of this gas could be sold into interstate commerce in exchange for like volumes to be returned to the producer at other times.

In addition, there are 85 contracts on file which permit the producer to elect to reserve a portion of the federal domain gas. The commission has not authorized any of this gas to be transported. A total of 737 billion cubic feet is subject to future reservation by producers under 55 of these 85 contracts.

\subsubsection{Benlefits and Costs}

DOI reports that average OCS production between November 1976 and March 1977 was 10.175 Bcf/day and during April-0ctober 1976, production was $9.928 \mathrm{Bcf} /$ day. Thus, production appears to increase during the winter as desired. The Secretary of Interior's request is estimated to have increased production by 23 billion cubic fieet during February and March 1977. Estimates of production increases possible by either voluntary or mandatory production increases are not available for the coming winter. However, hased on last year's experience, perhaps as much as $11.5 \mathrm{Bcf} /$ month could be obtained by such measures. In addition, FERC reports that $265 \mathrm{mmcf}$ per day of gas production is reserved for producer use. The cost to the producer of having his flowing reserved gas preempted, assuming it will be replaced by intrastate gas, is $\$ 1.41$ per mcf. (The December 1976 intrastate price in Louisiana was $\$ 1.95$ per mcf on the average, and the average interstate price in that state on the same date was \$.54.) Production of $737 \mathrm{Bcf}$ of reserved non-flowing gas over a ten year period would provide about $5.8 \mathrm{Bcf} / \mathrm{month}$. 
The measure involving the taking of currently non-flowing natural gas supplies under federal leases from producers who have reserved the right to keep these reserves for their own use is subject to legal and procedural difficulty. Time consuming formal hearings or rulemaking proceedings may be necessary, and any orders issued will be subject to requests to the courts for stays or other actions.

The gas flowing from federal leases current$1 y$ being used by producers in their own operations (refineries and petrochemical plants) often cannot be replaced without causing considerable disruptions. To the extent that the FERC has issued orders authorizing these deliveries, additional formal hearings will probably be necessary to effect any modification in these outstanding orders. The producers may make claims of injury which involve factual questions requiring formal hearings to modify prior authorization.

\subsubsection{Startup Plan}

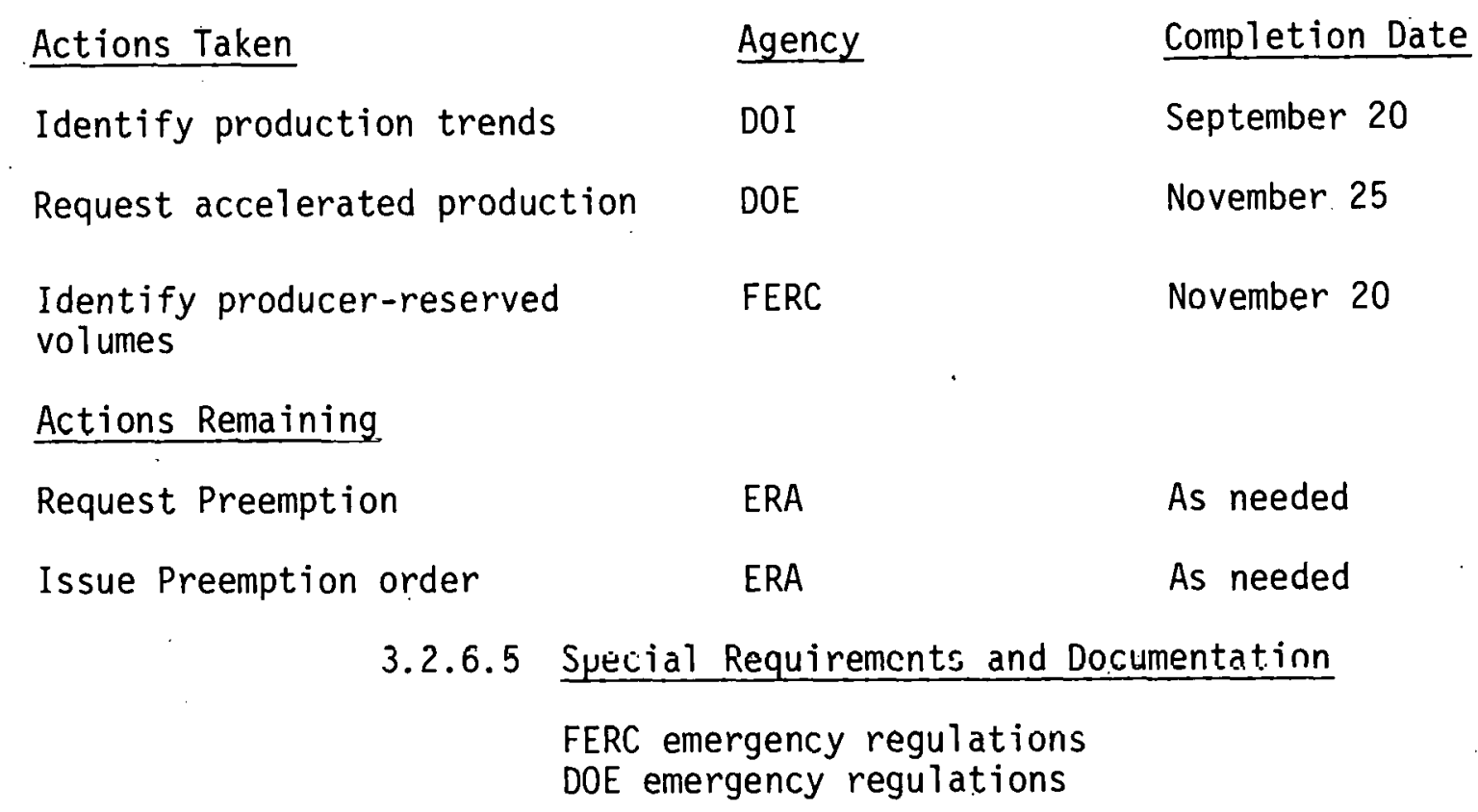




\subsubsection{Reallocate Federal Royalty Gas}

\subsubsection{Objective}

Use federal royalty gas to provide additional gas to heavily curtailed interstate pipelines.

\subsubsection{Concept of Operations}

FERC identifies the most and least heavilycurtailed interstate pipelines. The Department of Energy exercises its option to take the federal royalty in-kind from the least heavily curtailed pipelines when a customer of a heavily curtailed pipeline willing to purchase the gas has applied to and been approved by ERA. Transportation would be arranged by the purchaser. ERA would make program provisions known to all appropriate parties. To operate this program, both DOE and FERC would have to develop new regulations.

\subsubsection{Benefit and Cost}

This measure would provide a means of re. dressing some of the distortions in the distribution of interstate natural gas brought about by the accidents of historical contractual arrangements.

\section{Gulf of Mexico royalty gas receipts total}

516.8 Bcf during 1976. On a monthly basis, this represents $43.1 \mathrm{Bcf} /$ month which could be reallocated. This measure would deepen the deficiency on some pipelines while reducing it on others.

Many of the interstate pipelines currently receiving federal royalty gas that are not heavily curtailed are projecting relatively tight supply situations this winter and may request formal hearing on the basis of claimed injury regarding abandonment of service under the Natural Gas Act. Significant time delays may occur if such hearings are required.

\subsubsection{Startup Plan}

Actions Remaining

Draft regulations

Identify royalty recipients

Identify most and least

curtailed pipelines
Agency

DOE - FERC

DOE

FERC
Completion Date

November 1

As needed

As needed 
Actions Remaining (Con't $t$ )

Curtailed pipeline customer applies for royalty gas

Approve application

Issue royalty in-kind orders

Sel1 royalty gas to curtailed pipelines
Agency

(pipeline)

ERA

DOE

DOE

\section{Completion Date}

As required

Do

Do

Do

\subsubsection{Special Requirements and Documentation} FERC regulations on royalty gas (to be prepared) ERA regulations on allocation of royalty gas (to be prepared). 


\subsubsection{Permit Temporary Sales Arrangements}

\subsubsection{Objective}

Ensure that available intrastate natural gas can be purchased using emergency sales authority.

\subsubsection{Concept of Operations}

These measures utilize financial inducements and freedom from FERC jurisdiction to encourage movement of additional natural gas into interstate commerce. Pending passage of the National Energy Act, these sales can occur at unregulated prices for up to 60 days. Still unresolved is the impact of the level wellhead pricing rules of the NEA on the allowable prices for other than first sales of natural gas. Under current rules, these sales can be initiated by natural gas end users, local distribution companies, or interstate pipelines. FERC rules section 2.68 (See Exhibit 3.2.6), 157.22 and 157.29 provide that these sales do not require prior approval. However, either the seller or the transmission company must inform FERC within 10 days of commencement and termination of the emergency sales arrangements. Large quantities of gas are currently flowing to interstate pipelines under these procedures at this time.

In order to provide the available gas to the most appropriate purchaser, FERC regulation 2.68 could be amended to establish qualifications for end-users, enable distribution companies to initiate such arrangements, and preclude interstate pipelines from purchasing under its provisions unless they are in danger of curtailing priority 3 or higher.

\subsubsection{Benefit and Cost}

During February, 1977, 22.3 Bcf of additional natural gas were made available by these sales. In addition, an average of 19.4 Bcf per month were purchased under ENGA Section 6 authority. The price of ENGA purchases was \$2.25 ner Mcf while the February, 1977 pur... chases under FERC rules 2.68 and 157.22 ranged from $\$ 1.97$ to $\$ 3.19 \mathrm{pcr}$ Mcf.

\subsubsection{Startup Plan}

Actions Remaining

Revise FPC rule 2.68

Publish in guidebook FPC rule 2.68 (revised)
Agency

FERC

DOE/DOC
Completion Date

December 15

December 1 
Actions Remaining

Agency

Completion Date

Examples:

Notice of Commendement

Notice of Termination

Issue press release

DOE

December 1

、

(to be developed)
3.2.8.5 Special Requirements and Documentation

Amendment to FERC rule 2.68 as described above 


\title{
3.2.9 Allocate Under Section 4 of ENGA
}

\author{
3.2.9.1 Objective \\ Provide for allocation of natural gas for high \\ priority requirements.
}

\subsubsection{Concept of Operations}

Section 4 of ENGA, as amended by Section 418 of the NEA (H.R. 8444), contains authority for orders to protect high-priority customers (residential, commercial less than 50 Mcf on peak day, or 1 ife, health, physical property).

Any pipeline can be required to deliver to any other pipeline or distribution company. It is necessary to determine that the order will not create: high-priority shortages for the delivery pipeline; disproportionate deliveries or curtailments as compared to orders to other pipelines; or excessive transportation requirements. Alternate fuel must also be available. Nonjurisdictional pipelines will remain free of common carrier status (federal or state) and the Natural Gas Act. The act also provides that a governor may notify the President of a shortage and the volumes required and available to his/her state. Assistance can be obtained from industry with anti trust immunity if the attorney general's designee is in attendance, records are made available for public inspection, and the attorney general and FTC participate from the beginning. Rates of compensation for the gas is either per agreement of parties or by supplemental order of the Administrator.

\subsubsection{Benefit and Cost}

This measure would provide for the rodirection uf natural gas among states to avnid rurtailment of high priority elluusers. The benefits of this action are to provide a mechanism for ensuring that no state has a curtailment of its high priority natural gas users due to dislocations of the natural gas distribution system. This measure would require a state to use every means at its disposal to reduce the requirement prior to applying for redirection of supply from another statc.

The cost of implementation is minimal.

\subsubsection{Startup Plan}

Actions Takell

Draft regulation guidelines

Comments
Agency.

FPC

Various
Completion Date

August 17

September 20 
Actions Remaining

Extend and amend ENGA

Publish proposed regulation

Hearings

Issue rule
Agency

Congress

ERA

ERA

ERA
Completion Date

November 30

December 5

December 20

January. 5

3.2.9.5 Special Requirements and Documentation

$$
\text { None }
$$

Attachments

Exhibit 3.2.7 Emergency Natural Gas Act of 1977 (PL 95-2)

Exhibit 3.2.8 Amendments to ENGA (HR 8444) 
Exhibit 3.2.7

91 STAT. 4

PUBLIC LAW 95-2-FEB. 2, 1977

\section{Public Law 95-2 95th Congress}

\section{An Act}

Feb. 2, 1977

[S. 474]

Emergency Natural Gas Act of 1977 . 15 USC 717 nntr. 15 USC 717 note.

15 USC 717a.

15 USC $717 w$. 15 USC 717.

Natural gas emergenticy. 15 LSC 717 note.

Termination.
To authorize the President of the United States to order emergency deliveries and transportation of natural gas to deal with existing or imminent sliortages by providing assistance in meeting requirements for high-priority uses; to provide authority for short-term emergency purchases of natural gas; nui for other purposes.

Be it enacted by the Senate and House of Representatives of the United States of America in Congress assembled, That this Act may be cited as the "Fmergency Natural Gas Act of 1977".

IHFINTTINSK

SEc. 2. As used in this Act:

(1) The term "high-priority use" means-

(A) uss of nulural gas in a residence;

(B) use of natural gas in a commercial establishment in amounts of less than $50 \mathrm{Mcf}$ on a peak day; or

(C) any other use of natural gas the termination of which the President determines would endanger life, health, or maintenance of physical property.

(2) The term "interstate pipeline" means any natural-gas company, as defined in section 2(6) of the Natural Gas Act, which is engaged in the transportation by pipeline of natural gas.

(3) The term "intrastate pipeline" means any person (other than an interstate pipeline) engnged in the transportation by pipeline of natural gas.

(4) The term "interstate natural gas" means natural gas (other thnn nntural gac trensported pinsuarit to a transportation certificate issued under 18 C.F.R. 2.79) transported by an interstate pipeline in a facility which is certificated under the Natural Gas Act or which would be required to be so certificated but for section 1(c) of such Act.

(5) The term "local distribution company" menns any person (including a governmental entity) which receives natural cons for horal distribution and resale to natural gas users.

(6) The term "antitrust laws" means the Sherman Act (15 U.S.C. 1 et seq.), the Clayton Act (15 U.S.C. 12, 13, 14-19, 20, 21, 22-27), the Federnl Trade Commission Act (15 U.S.C. 41 et seq.), sections 73 and 74 of the VVilson Tariff Act (15 U.S.C. 8-9), and the Act of June 19, 1936, chapter 592 (15 U.S.C. 13, 13a, 13b, and 21a), and similar State laws.

(7) The term "State" means any Strite of the United States and the District of Columbia.

\section{PRFSIDTXTIAL DFCIARATIOY}

Src. 3. The President may declare a natural gas emergency if he finds that a severe natural gas shortage endangering the supply of natural gas for high-priority uses exists or is immiment in the United States or in any region thereof and that the exercise of his authoritics under section 4 is reasonably necessary, having exhausted other remedies to the maximum extent practicable, to assist in meeting requircments for such uses. Such emergency shall be terminated when the President finds that such shortages no longer exist and are no longer imminent. 
SEC. 4. (a) (1) If the President finds it necessary to assist in meet- 15 USC 717 note. ing the requirements for high-priority uses of natural gas (including shuit-term storage replenishment or injection for protection of highpriority uses), on the basis of a notification by the Governor of any State pursuant to subsection (c) or on the basis of other information available to the President, the President may, during a natural gas emergency declared under section 3, by order, require-

(A) any interstate pipeline to make emergency deliveries of, or

to transport, interstate natural gas to any other interstate pipeline or to any local distribution company served by an interstate pipeline for purposes of meeting such requirements;

(B) ainy intrastate pipeline to transport interstate natural gas from any interstate pipeline to another interstate pipeline or to any local distribution company served by an interstate pipeline for purposes of meeting such requirements; or

(C) the construction and operation by any pipeline of any facilities necessary to effect such deliveries or transportation.

No such delivery or transportation may continue after A pril 30,1977, or after the Presiclent terminates the emergency declared under section 3 , whichever is earlier.

(2) No order may be issued under this subsection unless the Presi- Order, dent determines that such order will not-
(A) create for the interstate pipeline delivering interstate (A) create for the interstate pipeline delivering interstate to be unable to meet the requirements for high-priority uses served, directly or indirectly, by such pipeline;

(B) result in a disproportionate share of deliveries or curtailments of natural gas experienced by such interstate pipeline when compared to deliveries and resulting curtailments which a re experienced as a result of orders applicable to other interstate pipelines (as determined by the President); and

(C) require transportation of natural gas by any pipeline in excess of its available transportation capacity.

(3) In issuing such order the President shall also consider the relative availability of alternative fuel to users of the interstate pipeline ordered to make deliveries pursuant to this section.

(b) Compliance by any pipeline with an order issued under subsection (a) shall not subject such pipeline to regulation under the Natural Gas Act (15 U.S.C. 717 et seq:) or to regulation as a common carrier under any provision of State or Federal law. No action required to be taken under an order issued under subsection (a) shall be subject to any provision of the Natural Gas Act and any such order shall supersede any provision of a certification, or uller requirement, under the Natural Gas $\Lambda$ ct which is inconsistent with such order.

(c) (1) The Governor of any State may notify the President of any finding by such Governor that a shortage of natural gas within such State, endangering the supply of natural gas for high-priority uses, exists or is imminent and that the State, and agencies and instruinentalities thereof, have exercised their authority to the fullest estent practicable and reasonable under the circumstances to overcome such shortage.

(2) The Governor shall submit, together with any notification under paragraph (1), information upon which he has based his finding under such paragraph, including-

(A) volumes of natural gas required to meet the requirements for high-priority uses in such State;

Requirements for delivery by interstate or intrastate pipelines.
Altemative fuel, availability.

Notification of shortage by State Governor. 
91 STAT. 6

PUBLIC LAW 95-2-FEB. 2, 1977

(B) information received from persons in the business of producing, selling, transporting, or delivering natural gas in such State as to the volumes of natural gas available in such State; and

(C) such other information as the Governor determines appropriate to apprise the President of emergency deliveries and transportation of interstate natural gas needed in such State.

(d) The President may request that representatives of interstate pipelines, intrastate pipelines, local distribution companies, and other persons meet and provide assistance to the President in carrying out his authority under this section.

Authority to obtain information.

Compliance order.

Compensation. Hearing; supplemental order.

(e) (1) In order to obtain information to carry out his authority under this Act, the President may-

(A) sign and issue subpenas for the attendance and testimony of witnesses and the production of books, records, papers, and other documents;

(B) require any person, by genexul or speclal order, to submit ansivers in writing to interrogatories, requests for reports or for other information, and such answers shall be made within such reasonable period, and under oath or otherwise, as the President may determine; and

(C) secure, upon request, any information from any Federal department or executive agency.

(2) The appropriate United States district court may, upon petition of the Attorney General at the request of the President, in the case of refusal to obey a subpena or order of the President issued under this subsection, issue an order requiring compliance therewith, and any failure to obey an order of the court may be punished by the court as a contempt thereof.

(f) (1) If the parties to any order issued under subsection (a) fail to agree upon the terms of compensation for deliverics (which may include compensation in kind) or transportation required pursuant to such order, the President, after a hearing held either before or after such order takes effect, shall, hy supplemental order, prescribe the amount of compensation (which may include compensation in kind) to be paid for such deliveries or transportation and for any other expenses incurred in delivering or trnnsporting euch gas.

(2) If, for the purpose of a supplemental order pursuant to paragraph (1); the party making emergency deliveries pursunt to subsection (a) -

(A) indicates a preference for compensation in kind, the President shall direct that compensation in kind be provided by. August 1, 1977, to the maximum extent practicable,

(B) indicates a preference for compensation, or the President determines pursuant to paragraph (A) of this subsection that any portion thereof cannot practicubly be compensated in kind, the President shall calculate the amount of compensation for deliveries of natural gas, based upon the amount required to make the interstate pipeline delivering such natural gas and its local distribution companies whole for loss of sales resulting therefrnm; including the actual curount pald by such interstate pipeline or any of its local distribution companics for the volumes of naturul gas or higher cost gas such as synthetic natural gas which were needed to replace natural gas delivered pursuant to an order under subsection (a); and for.transportation, storage, and other expenses, based upon reasonable costs, as determined by the
President. 
(g) In order to effect the purposes of this Act, the President shall monitor the operation of any order made pursuant to this section to assure that natural gas delivered pursuant to this section is applied to high-priority uses only.

\section{ANTITRUST PROTECTIONS}

Sec. 5. (a) There shall be available as a defense for any person to civil or criminal action brought for violation of the antitrust laws (or any similar law of any State) with respect to any action taken or meeting held pursuant to a request ol order of the President under section 4 (a) or (d) of this Act, if-

(1) such action was taken or meeting held solely for the purpose of complying with the President's request or order;

(2) such action was not taken for the purpose of injuring competition; and

(3) such person complied with the requirements of subsection (b) of this section.

Persons interposing the defense provided by this subsection shall have the burden of proof, except that the burden shall be on the person against whom the defense is asserted with respect to whether the actions were taken for the purpose of injuring competition.

(b) A meeting held pursuant to a request by the President under section $4(d)$ or pursuant to an order under section 4 (a) complies with the renuirements of subsection (a) if-

(1) there is present at such meeting a full-time Federal employee designated for such purposes by the Attorney General:

(2) a full and complete record of such meeting is taken and deposited, together with any agreements resulting therefrom, with the Attorney General, who shall make it available for public inspection and copying;

(3) the Attorney General and the Federal Trade Commission have the opportunity to participate from the beginning in the developinent and carrying out of agreements and actions under sections $4(a)$ and $4(d)$, in order to propose any alternative which would avoid or overcome, to the greatest extent practicable, possible anticompetitive effects. while achieving substantially the purposes of this Act; and

(4) such other procedures as may be specified in such request or order are complied with.

\section{EMTERGENCY. PURCHASES}

SEc. 6. (a) The President may authorize any interstate pipeline or local distribution company served by an interstate pipeline (or class or category of such pipelines or companies) to contract, upon such terms and conditions as the President determines to be appropriato (including provisions respecting fair and equitable prices), for emergency supplies of natural gas for delivery before August 1,1977 -

(1) from any producer of natural gas (other than a producer who is affiliated with the purchaser as determined by the President) if (A) such natural gas is not produced from the Outer Continental Shelf and (B) the sale or transportation of such gas was not, immediately before the date on which such contract was entered into, certificated under the Natural Gas Act, or

(2) from any intrastate pipeline, local distribution company, or other person (other than in interstate pipeline or a producer of natural gas).
Delivery to highpriority users only.

15 USC 717 note.

15 USC 717 note. 15 USC $717 \mathrm{w}$. 
91 STAT. 8

\section{Emergency} purchase contract; court approval. 15 USC 717w.

"Outer Continental Shelf."

15 USC 717 note.$$
\text { its }
$$
its local distribution companies shall be creditec to such local distribution companies in proportion to thoir share of any natuial gus not: delivered together with credits necessary to make whole any local clistribution coinpany which replaced such natural gas with higher cost gas such as synthetic natural gas as prescribed in section 4 (f) (2) (B). Compensation paid by an interstate pipeline for deliveries or emergency purchases of matural gas pursuant to section 4 or section 6 shall be charged to such interstate pipeline's local distribution companies in proportion to thejr share of such natural gas deliveries or purchases.

\section{RELATIONSHIP TO NATOKAL GAS ACT}

15 USC 717 note. SEc. 8. Except as expressly provided in this Act, nothing contained in this Act shall be interpreted to change, modify, or otherwise nffect rules, regulations, or other regulatory requircments or procedures of the Federal Power Commission pursuant to the provisions of the 15 USC 717w. Natural Gas Act.

\section{FFFECT OF CEITTAIN CONTRACTCAL OBLIOATIONS}

15 USC 717 note. Sec. 9. (a) There shall be available as a defonsc to any action brought for breách of contract under Federal or State law arising out 
of any act or omission that such act was taken or that such omission occurred for purposes of complying with any order issued under section 4 (a).

(b) Any contractual provision-

(1) prohibiting the sale or commingling of natural gas subject to such contract with natural gas subject to the provisions of the Natural Gas Act, or

(2) terminating any obligation under any such contract as a result of such sale or commingling,

is hereby declared against public policy and unenforceable with respect to such natural gas if an order under section 4 (a) or an anthorization under section 6(a) applies to the delivery, transportation, or contract for supplies of such natural gas.

(c) The amounts and prices of any natural gas purchases pursuant to an order under section $4(a)$, an authorization under section $6(a)$, or a contract entered into pursuant to 18 C.F.R. 2.68 after the date of the enactment of this Act and before August 1, 1977, shall not be taken into account for purposes of any contractual provision which determines the price of any natural gas (or terminates the contract for the sale of natural gas) on the basis of sales of other natural gas.

\section{ADMIINISTRATIVE PROCEDURE, AND JUDICIAL REITEW}

SEc. 10. (a) Subchapter II of chapter 5 of title 5 of the Tinited States Code (other than sections 554, 556, and 557 thereof) shall apply to orders and other actions under this Act.

(b) Except with respect to enforcement of orders or subpenas under section 4(e), the Temporary Emergency Court of Appeals, established pursuant to section 211(b) of the Economic Stabilization Act of 1970, as amended, shall have exclusive original jurisdiction to review all civil cases and controversies under this Act, including any order issued, or other action taken, under this Act. The Temporary Emergency Court of Appeals shall have exclusive jurisdiction of all appenls from the district courts of the United States in cases and controversies arising under section 4(e) of this Act; such appeals shall be taken by the filing of a notice of appeal with the Temporary Emergency Court of Appeals within thirty days of the entry of judgment by the district count.

(c) Prior to a final judgment, no court shall have jurisdiction to grant any injunctivu relief to stay or defer the implementation of any order issued, or action taken, by the President under this Act.

\section{ENFOREENENT}

SEc. 11. (a) Any person who violates an order or supplemental order issued under section 4 or an order under section $6(\mathrm{c})$ shall be subject to a civil penalty of not more than $\$ 25,000$ for each violation of such order. Each day of violation shall constitute a separate offense.

(b) Any person who willfully violates an order or supplemental order issued under section 4 or an order under section 6(c) shall be fined not more than $\$ 50,000$ for each violation of such order. Each day of violation shall constltute a sepurale violation.

(c) Whenever it appears to the President that any individual or organization has pncaged, is engaged, or is about to engage in acts or practices constituting a violation of any order issued under sectlon 4(a), any supplementä order issued under section $4(f)$; or any order under section 6(c), the President may request the Attorney General to bring a civil action to enjoin such acts or practices and, upon showing, a temporary restraining order or preliminary or permanent

15 USC 717 note. 15 USC 551 .

12 USC 1904 note.

Filing of notice of appeal.

15 USC 717 note. 
Mandatory injunctions.

Report to President. 15 USC 717 note.

Report to Congress.

15 USC 717 note.

Sec. 13. The President may delegute all or any portinn of the suthorItyy granted to him under this Act to such executire agencies (within the meaning of 5 U.S.C. 105) or officers of the Urited States as he determines appropriate, and may authorize such redelegation as may bo appropriate. Except with respect to section $5 \overline{2} 2$ of title 5 of the United States Code, any officer or executire agency of the United States to which authority is delegated or redelegated under this Act shall be subject only to such procedural requirements respecting the exercise of such authority as the President would be subject to if such authority were not so delegated.

\section{PREEMIPTION OF INCONSISTENT STATE OR LOCAL ACTION}

15 USC 717 note.

SEc. 14. Any order issued pursuant to this Act shall preempt any provision of any program for the allocation, emergency delivery, transportation, or purchase of natural gas established by any State or local government if such program is in conflict with any such order.

$\Lambda$ ppróved February $2,1977$.

\author{
LEGISLATIVE HISTORY: \\ HOUSE REPORT No. 95-7 (Comm. of Conference). \\ CONGRESS:ONAL RECORD, Vol. 123 (1977): \\ Jan. 26, 28, 31, considered and passed Senate. \\ Feh. 1, considered and passed House, amended. \\ Feb. 2, Senate and House agreed to couference report. \\ WEEKLY COMPILATION OF PRESIDENTIAL DOCUMENTS, Vol. 13, No. 6 : \\ Feb. 2, Presidential statement.
} Note.-A chenge has been made in the olip law format tu pruvile fur une-Umo
preparation of copy to be used for publication of both slip laws and the United
Stutes Statutes at Large volumes. Comments from users are invited by the Office of
the Federal Register, National Archives and Recorde Service, Washington, D.C.
20408 . 
EXHIBIT 3.2.8

\section{SEC. 418. AMENDMENTS TO THE EMERGENCY NATURAL} GAS ACT OF 1977.

5 The Emergency Natural Gas Act of 1977 is amended-

(1) in section 2 , by striking out paragraphs (2),

(4) and inserting in lieu thereof the

8 following:

"(2) The term 'pipeline' means any person engaged

10 in the transportation of natural gas.";

(2) in section 2 , by redesignating paragraphs (5), $(6)$, and (7) thereof as (3), (4), and (5), respec-

13 tively;

(3) in section $4(a)$ (1), by striking out subparagraphs (A) and (B) and inserting in lieu thereof 16 the following:

"(A) any pipeline to make emergency deliveries of, or to transport, natural gas to any other pipeline or to any local distribution company for purposes of meeting such requirements; or";

(4) in section $4(\mathrm{a})(1)$, by redesignating subparagraph (C) thereof as subparagraph (B) ;

(5) in section 4 (a) (1), by striking out "April 30, 1977" and inserting in lieu thereof "April 30, 1979"; 
(6) in section 4 (a) (2), by striking out "inter-

2 state" wherever it appears;

(7) in section $4(a)(3)$, by striking out "inter4 state";

Ј

6

7

$y$

9

10

11

12

13

14

15

16

17

18

19

20

21

22

23

24

(8) in section $4(\mathrm{~d})$, by striking out "interstate pipelines, intrastate";

(9) in section 4 (f) (2) (A), by striking out "by $\Lambda$ ugust 1, 1977, to the maximum extent practicable," and inserting in lieu thereof "as expeditiously as practicable,";

(10) in section $4(f)(2)(B)$, by striking out "interstate" both places it appears;

(11) in section 7, by striking out "an interstate pipeline" both places it appears and inserting in lieu thereof "a pipeline" and by striking out "such interstate" and inserting in lieu thereof "such";

(12) in section 9(c), by striking out "August 1, 1977," and inserting in lieu thereof "April 30, 1979,"; and

(13) in section 12 (b), after "October 1, 1977,", by inserting "October 1, 1978, and June 1, 1979,". 


\subsubsection{Ban Use of Natural Gas as a Boiler Fuel}

\subsubsection{Objective}

Minimize use of natural gas as a boiler

fuel during an emergency periad.

\subsubsection{Concept of Operations}

Program would be authorized when enacted by

section 631 (b) of NEA (HR 8444) or section 137 of HR 4018 as amended by the Senate.

The program could be executed by states or Federal Government and would be a required action for states to implement prior to requesting allocation of natural gas by the Federal Government under section 4 of ENGA. The prohibition under section 631 (b) of NEA could be for no more than 90 days without the opportunity for a one-house veto by Congress under section 551 of EPCA. Prohibition under section 137 of HR 4018 could only remain in effect for the duration of the natural gas emergency declared by the President under section 3 of ENGA.

The ban would only apply to boilers with a design firing rate in excess of $100 \mathrm{~mm}$ btu/hr which have the capability to burn alternate fuel or be split-fired (e.g., mixed oil and gas) and for which alternate fuel is or can be made available.

\subsubsection{Benefits and Cost}

Approximately 25 Bcf per month of natural gas would be available from power plants and up to 142 Bcf per month from other major fuel burning installations. Until further research is conducted the assumption is made that at least 50 Bcf per month could be provided by the measure. The incremental cost of alternate fuel may be as low as $\$ 0.76$ per Mcf.

\subsubsection{Startup Plan}

\begin{tabular}{|c|c|c|}
\hline Actions Remaining & Agency & Completion Date \\
\hline Enact legislation & Congress & November 30 \\
\hline $\begin{array}{l}\text { Publish proposed } \\
\text { regulations }\end{array}$ & ERA & December 5 \\
\hline Hearings & ERA & December 20 \\
\hline Issue final rule & ERA & January 5 \\
\hline $\begin{array}{c}\text { Prohibit boiler fuel } \\
\text { use of natural gas }\end{array}$ & ERA & As required \\
\hline
\end{tabular}


3.2.10.5 Special Requirements and Documentation

developed).

Legislation and regulations (to be

Attachments

Exhibit 3.2.9 1974 Gas Consumption of Major Gas Combustors

Exhibit 3.2.10 Calculation of Increased Power Plant Cost of Boiler Fuel Ban

Exhibit 3.2.11 Section 631 of National Energy Act ( $\mathrm{Hr} 844$ )

Exhibit 3.2.12 Section 137 of HR 4018 (Glenn Amendment) 
Exhibit 3.2.9

1974 GAS CONSUMPTION OF MAJOR GAS COMBUSTORS*

DIST́RIBUTED BY PRIMARY AND ALTERNATE FUEL CAPABILITIES

(A11 Data Shown Represent Gas Consumption in Billions of Btu's)

Gas Consumption as Primary Fuel

No Alternate Fuel

$1,265,825.5$

Alternate Fuel

Resid

Distillate

$643,751.9$

Coal

Other

Subtotal

$438,086.1$

$120,151.0$

$121,088.0$

$1,323,077.0$

Gas Consumed as A7ternate Fuel

Primary
Resid
Distillate
Coal
Other
Subtotal

Total Gas Consumed

Gas Consumed by Plants Having Alternate Fuel Capability

Percent of Total Gas Consumed
$87,979: 7$

$6,081.7$

$70,555.5$

$117,201.6$

$281,758.5$

$2,870,661.0$

$1,604,835.5$

$55.9 \%$

* Major gas combustors are those individual combustors within an MFBI with a design firing rate of $100 \mathrm{MMBtu} / \mathrm{hr}$. or greater which burned gas in either 1973 or 1974 .

Source: EPA, Office of Air Quality Planning and Standards, "The Impact of Natural Gas Shortage on Major Industrial Fuel Burning Installations," drafl, Jan., 1977, Schedule A-4. 
Exhibit 3.2.10

CALCULATION OF BOILER FUEL BAN

INDUSTRY COST:

Given - Dec 1976 retail price of Resid. 1.0 percent sulphur

$=\$ 12.76 / \mathrm{bbl}$

- Dec 1976 industrial sale price of natural gas

$=\$ 1.313 /$ Mcf

Conversion factors;

Resid $6.287 \times 10^{6}$ BTU/Bb]

Natural Gas 1,021 Btu/cf

$\$ 12.76 \div 6.158=\$ 2.07 / \mathrm{Mcf}$

BTU EQUIVALENT PRICE OF RESID

$2.07-1.31 \equiv \$ 0.76$ increased cost of fuel

Source: Monthly Energy Review, FEA June 1977 
Exhibit 3.2.10 (Continued)

\section{POWERPLANT COST: $1 /$}

Given:

Dec 1976 Steam Electric Utility Plants cost of Natural Gas (national average) $=111.3$ cents $/ \mathrm{mmbtu}$

Dec 1976 Residual Fuel $0 i 1$ Cost $=207.5$ cents $/ \mathrm{mmbtu}$

$207.5-111.3=86.2$ cents $/ \mathrm{mmbtu}$

Conversion Factor:

$1,021 \mathrm{btu} / \mathrm{cf}$

$\frac{\$ .862}{10^{6} \mathrm{btu}} \times 1,021 \quad \times \quad \frac{10^{3} \mathrm{btu}}{\mathrm{cf}}=\$ .8801 / \mathrm{mcf}$

Source:

Monthly Energy Review, FEA, June 1977

1/Excludes incremental costs caused by additional maintenance, oil transportation and storage and reduction in plant output. 
Exhibit 3.2.11

Section 631 of National Energy Act (HR 8444)

SEC. 631. EMERGENCY POWERS OF THE PRESIDENT.

(a) If the President-

(1) declares a severe energy supply interiuption, as defined in section $3(8)$ of the Energy Polioy and Conservation Act, or

(2) finds, and publishes such finding; that a national or' regional fuel supply shortage exists or may cxist which the Presillent determines-

(A) is, or is likely to be, of significant scope and duration, and of an emergency nature;

(B) causes, or may cause, major adverse inpact on public health, safcty, or nelfare or on the economy; and

(C) results, or is likely to result, from an interuption in the supply of coul or from sabotage, or an act of God; 
1 the President may, by order, allocate coal to any electric

2 porierplant or major fuel-burning installation, in accord-

3 ance with such terms and conditions as he may prescribe,

\pm to insure reliability of electric service or prevent unemploy-

5 ment, or both.

c (b) In the event the President declares a severe energy

T supply interruption, as defined in section $3(8)$ of the Energy

S Policy and Conservation Act, the President may, by order,

9 probibit any new or existing electric powerplant or major

10 fuel-burning installation from using natural gas or petroleum,

11 or both, as a primary energy soutce for the period specified

12 in the order. Any such order may authorize a waiver or

13 modification of any Federal, State, or local law, standard,

14 limitation, or other requirement applicable to emissions. of

15 envïrommental pollutants or any applicable environmental

16 requirement if the President finds, and publishes such find-

17 ing in the Federal Register, that such waiver or modifica-

18 tion is necessary by reason of the probibitions of such order

19 (and the supply interruption on which it is based) and that

20 no alternative means are practicable which would result in

21 compliance with such envirommental requirements. Any such

22 waiver or modification shall be made under such terms and

23 conditions as the President may prescribe to insure com- .

$2 t$ pliance with applicable environmental requirements to the

25 maximum extent practicable under the circumstances. Such 
1 waiver or modification may cause or contribute to a viola-

2 tion of a primary ambient air quality standard only to the

3 extent the President finds and publishes his finding that no

4 alternative means are practicable to avoid such violation.

5 (c) The President may, by order, stay the application

6 of any provisions of this part, or any rule or order there-

7 under-

8

9

10

11

12

13

14

15

16

17

18

19

20

21

22

23

24

24 (2) Any such order may be extended by a sulsequerii
25 . order which the President shall transmit to the Congress in

8 (1) in thr rase of ariy provision, rule, or order applicable to any new or existing electric powerplant, if the Federal Porrer Commission finds, and publishes such finding, that an emergency exists, duc to national, 2 regional, or system wide shortages of coal or other fuels, or disruption of transportation facilities, which emergency is likely to affect reliahility of service of any such electric powerplant; and

(2) in any other case, to tho extent the President determines is necessary to alleviate or prerent any emergency adversely affecting the public health, safety, or welfare.

(d) (1) Except as prorided in paragrnph (3): am! order issued by the President under this section shall nor br effective for longer than the duration of the interruption or emergency, or 90 days, whicherer is less.

(2) Any such order may be extended by a sulsequeni
5 - order which the President shall transmit to the Congress in 
- 1 accordance with section 551 of the Energy Policy and Con-

2 servation Act. Such order shall be subject to congressional

3 review pursuant to such section.

4 (3) Notwithstanding paragraph (1), any order issued

5 under this section shall remain effective throughout the 15-

6 calendar-day period during which any order described in

7 paragraph (2) is subject to eongressional review under

8 section 551 of the Energy Policy and Conservation Act.

9 (e) The authority of the President to issue any order

10 under this section may not be delegated. This subsection

11 shall not be construed to prevent the President from direct-

12 ing any Federal agency to issue rules or regulations imple-

13 menting such order.

14 (f) Any order issued under this section shall be pub-

15 lished in the Federal Register. To the greatest extent prac-

16 ticable, the President shall, before issuing any order under

17 this section, but in no event later than 5 days after issuing

18 such order, report to Congress of his intention to issue such

19 order and state his reasons therefor. 


\section{EXHIBIT 3.2 .12}

1 EMERGENGY CONYERSIONS OF UTILITIES AND OTHER

SEC. 137. (a) During a natural gas emerciencer de4 clared under section 3 of the Emorgency Tatural Gas Act 5 of 1977 (15 U.S.C. 717), the Secretary may, by order 6 I prolitbit any electric utility porerplant or majos fucl-biurning $7^{\prime}$ installation from burning natural gas if the Secrefary deter8 mines that:

9 (1) such electric utility powcrnlant or installation 10 had on Septemler 1, 19\%i (or at any time thereafter)

i1 the capability to.burn petrole'm products without damage

12 to its facilities or equipinent and without interference with 13 ifs production processes;

14 (2) an order under section 2(a) of the Energy 15 Supply and Environmental Coordination Act of 1974 16 (15 U.S.C. 792(a)) has not been issued with respect 17 to such electric utility pouierplant or installation; (3) significant quantities of mulural gas olherwise 19 burned by such clectric utility pourerplant or instrllation 20 are expected to to saved prior to the tormination of the 21 emergency declared under section 3 of the Emergrncy 22 Natural Gas Act of 1977 (15 C.S.C. FI7); and

(4) petrolcum products will be areilable during the 
1 (b) The Secretary may specify in uny order issued

2 under this section the periods of time during uhich suck order

3. will be in effect and the quantity (or rate of use) of nalural

4 gas that may be burned by an electric utility powerplant or

5 major fuel-burning installation during such period, includ-

6 ing the burning of natural gas by an electric utility powcr-

7 plant to meet peak load requirements. No such order ma!s

8 continue in effect after the President terminates the emergency

9 declared under section 3 of the Einergency Natural Gas Act

10 of 1977 (15 U.S.C. 717).

11 (c) The Secretary shall exempt from any order issucd 12 pursuant to this section the burning of mantral gras for the 13 necessary processes of ignition, startup, testing, and flame 14 stabilization by a facility.

15. (d) The Secretary shall modify or suspend any order 16 issued pursuant to this section to the extent necessary to. 17 alleviate short-term air quality emergencies or other danger 18 to the public health, or welfare.

19 . (e) Prior to a final judgment, no court shall have juris20 diction to grant any injunctive relief to stay or defer the 21 implementation of amy order issucd under this section.

22 (f) For purposes of this section, the term "electric 23 utility powerplant means a fossil-fuel-fired electric generat24 ing unit, including a gas turbine unit or a combined cycle 
1 unit, that produces electric power for the purposes of sale or

2 exchange.

3 (g) For purposes of this section, the term "major fuel-

4 burning installation" means a unit other than an electric

5. utility powerplant consisting of a boiler, gas turbine unit,

6 combined cycle unit, or internal combustion engine which-

7. (A) has a design capability of consuming any fuel

8 (or miaturc or combination llerevf) at a fuel heat input

9 rate of one hundred million Btu's per hour or greater; or

$10(B)$ is a combination of two or more such units

1. (cxcluding, if determined appropriate by the Adminis-

12 trator, any such unit having a design capability to con-

13 sume any fucl (or mixture or combination thereof) at

14 a fuel heat input rate of less than one luredred million

15 Btu's per hour) which are located at the same site and

16 which in tho aggregate have a design capability of

17 consuming such fuel at a fuel heat input rate of two

18 hundred and fifty million Btu's per hour or greater.

19 (h) The Commission shall, not later than ninety days

20 after the date of enactment of this subtitle, promulgate reg-

21 ulations which shall provide for just compensation to all

22 parties involved in the sale and transportation of natural gas

23 made available as a result of any order issued under this

24 section. In arriving at a determination of just compensa-

25 tion, the Commission shall make provision for full compensa- 
1 tion and reimbursement for increased costs, if any, includiny

2 but not limited to,

3 (A) the cost of heavy petroleum fuel oil substituted

4. for natural gas,

$5 \quad(B)$ the cost of fuel transportation, handling and

6 storage,

7 (C) costs resulting from pourerplant operations and

8 maintenance and decreased fuel efficiency, plus

9 (D) a proportionate share of thic average costs of its

10 gas system, if any,

11 incurred by the owner or operator of an electric pouverplant.

12 or major fuel.burning:installation: Provided, however, That

13 just compensation may not include any compensation for

14 capital expenditures, as defined by generally accepted account-

15 ing principles made in connection with conversion from nat-

16 ural gas to heavy petroleum fuel oil capability: Provided

17 further, That, in the case of an intrastate pipeline company

18 involved in the transportation of such nalural gas, the term

19 "just compensation" means the fee such intrastate pipclinc

20 company is then currently charging others for similar service. 


\subsection{Electricity and Fuel Switching Actions}

The electric utilities, because of their extensive, interconnected network and historic, cooperative operation, are looked to for a significant contribution to relieve a shortage of one or more fossil fuels. Of the 445 gigawatts (gw) of fossil-fueled electric generation capacity, 48 percent is coal-fired, 31 percent is oil-fired, 17 percent is gas-fired. The remaining four percent is generated by other sources such as waste heat, solid waste, etc. Approximately 21 percent of the national electrical generation capacity is nuclear or hydro and unaffected by shortages of fossil fuels.

The measures under consideration for use in an energy emergency can limit the impact of a shortage of one fossil fuel by importing power from other areas which do not depend as heavily on that fuel or by providing for voluntary and, if necessary, mandatory load reductions. In many cases, theses are actions normally taken by the FERC, state PUC's, or the power industry to prevent or limit electrical shortages.

The electrical utility industry has established a significant capability and has often demonstrated its willingness to share power among adjacent systems. These arrangements are effective in cases where no adverse economic impact will accrue to the customers of the provider utility or system. In an extreme emergency where life, health or property are threatened in one area, it may be necessary to reduce service to another area and transfer minimal power, thus incurring an adverse economic impact. At these times, the Federal Government may be required to order the transfer and accept the concomitant esonomic problems.

Availabie records show that 51 percent of fossil-fueled electrical generation capacity has at least part-time alternate fuel capability. Of those power plants for which information on primary fuel is available, 44 percent of the oil-fired and 81 percent of the natural gas-fired plants are repurted to have at least partial alternate fuel capability.

As with other measures, fuel switching and importation of electrical energy involve additional costs. It is necessary to consider very carefuliy the economic impact of these actions on the service areas of the provider, any intermediate transmission company, and the recipient utility.

\subsubsection{Power Pool Fuel Sharing Agreements}

\subsubsection{Objective}

Encourage power pools to formalize agreements to share fuel on a one-system basis and establish uniform service curtailment plans in all jurisdictions served. 


\subsubsection{Concept of Operations}

Cooperative agreements among electric utilities to share fuel on a one-sy,stem basis to produce electrical energy to meet the combined load of ail power pool members will be fostered. Examples for this measure are the agreements of the Pennsylvania, New Jersey, and Maryland (PJM) power pool and the New England and New York power pools.

The Federal Government will encourage these agreements, and work with the various state regulatory bodies and the power pools to establish meaningful agreements.

To the extent necessary, the states should expedite removal of regulatory prohibitions on such agreements.

Based on the PJM Agreement, power pools should establish cooperative fuel sharing agreements.

In order to ensure uniformity of response, all states should approve mandatory load reduction measures when called for by the agreements.

\subsubsection{Benefits and Cost}

These agreements are beneficial because they reduce the impact of shortages in local areas. However, because certain power systems take greater risks than others and maintain low inventories of fuel, these measures may result in customers of one system subsidizing customers of another.

\subsubsection{Startup Plan}

Actions Taken

Circulate PJM agreement

Contact power pools

Foster agreements

Actions Remaining

Monitor agreements
Agency Completion Date

Various August 29

FPC September 15

FEA September 30

DOE Continuous

3.3.1.5 Special Requirements and Documentation.

State approval of agreements and authorization of mandatory conservation measures, when required 


\subsubsection{Reduce Uranium Enrichment Load}

\subsubsection{Objective}

Provide emergency electrical generating capacity by reducing production of enriched uranium.

\subsubsection{Concept of Operations}

DOE will release from its gaseous diffusion plants limited amounts of electric power to its electric utility suppliers at their request for a minimum period of 30 days if given assurance that withou.t assistance substantial curtailment of residential and commercial consumer electric power loads in a given area will probably be necessary.

To avoid any increase in the cost of uranium enrichment services provided to its customers, DOE must be compensated for any costs or losses in efficiency resulting from a reduction in power loads.

Any power reduction would be between ERDA and its power suppliers. The suppliers would be responsible for all arrangements to transfer released power to the areas facing emergency shortages.

DOE will not give up power and production to alleviate an emergency if an alternative source is availiable on a firm basis when needed during the period of emergency.

DOE will not reduce production by giving up power simply because alternative sources of power are more costly.

Prior to any reduction in power, DOE expect a written agreement on the terms and conditions that apply to the reduction.

\subsubsection{Benefit and Cost}

DOE can reduce use at the rate of about $10 \mathrm{MW}$ per hour for a minimum period of 30 days. The gaseous diffusion plants and their electric power suppliers are as follows:

\begin{tabular}{ll} 
Gaseous Diffusion Plants & Supplier \\
\hline Portsmouth, Ohio & Ohio Valley Electric Corp. (OVEC) \\
Paducah, Kentucky & Elec. Energy, Inc. (EEI) \\
Oak Ridge, Tenn. & Tenn. Valley Authority (TVA)
\end{tabular}

During the period December, 1977 - March, 1978, these plants will be operating at $5640 \mathrm{MW}$ : 
Site

Oak Ridge, TN

Paducah, KY

Portsmouth, $\mathrm{OH}$

\begin{tabular}{ll}
$\begin{array}{l}\text { Operating } \\
\text { Leve1 (MW) }\end{array}$ & $\begin{array}{l}\text { Floor } \\
\text { Level (MW) }\end{array}$ \\
\hline 1525 & 400 \\
2140 & 600 \\
1975 & 400 \\
5640 & 1400
\end{tabular}

In addition to normal generating and transmission charges charged by the suppliers, DOE requires compensation at the rate of 5.5 to $6.5 \mathrm{mils}$ per $\mathrm{kwh}$ and a one-time charge of $\$ 400$ per meqawatt reduction.

\subsubsection{Startup Plán}

Actions Taken

Agency

Completion Date

Memorandum containing

procedures issued

OEP

April 1977

Update drafted

ERDA

August 1977

Actions Remaining

Notify DOE of power

requirement

Power

supplier

When unable to meet peak demands from own or other sources

Notify supplier of intent to reduce requirements
3.3.2.5 Special Requirements and Documentation

Exhibit 3.2.13 DOE Load Shedding Implementation Plan 


\section{IMPLEMENTATION PLAN}

\section{Actions by DOE (or FPA)}

Where DOE or FPA is contacted by a system within feasible transmission distance of the suppliers to gaseous diffusion plants concerning an electric power problem of such magnitude that the system cannot meet its peak demands from its own capacity or by purchase from other systems, the utility in need of power will be advised of the potential availability of power from the gaseous diffusion plants suppliers by a reduction in DOE usage, and of the policy on release of power. At the same time the DOE (or FPA) representatives will inform DOE headquarters and FPA (or DOE) of the request b.y phone.

II. Actions by Electric Utilities

The electric utility faced with the shortage will:

(1) Ascertain whether the transmission capacity will be available between its systcm and the system of the power supplier serving the gaseous diffusion plant;

(2) Contact, through the interconnecting system, one or all the suppliers of electric power to the gaseous diffusion plants, as appropriate, stating that it has exhausted all other sources for obtaining electric power and request that the electric power supplier make arrangements with DOE for effecting the reduction;

(3) State the amount of power needed and the period of reduction;

(4) Provide the Manager, Oak Ridge Operations Office (telephone 615-483-8611), or his designee, and the power suppliers assurance that, without. the assistance of DOE power, substantial curtailment of electric power to residential and commercial consumers in the area will be necessary;

(5) Where OVEC or EEI is the supplier, agree to pay the interconnected utility for power and energy so released by DOE. DOE will, in turn, be compensated by OVEC or EEI for associated cost penalties which it incurs due to the reduction, the amount of 5.5 to 6.5 mills per kilowatt-hour at. 100 percent load factor and 
a one-time charge for each reduction of 400 per megawatt. The surcharge is based on maintaining a 3-plant load level of not less than $1400 \mathrm{MW}$, i.e., each at 0ak Ridge and Portsmouth and $600 \mathrm{MW}$ at Paducah. In the event it is determined that reductions are to be made below these minimum levels, the amount of the surcharge will be appropriately increased to cover the consequent increase in the associated cost penalties.

(6) Where TVA is the power supplier, advise the Manager, Oak Ridge Operations Office (telephone 615-483-8611), or his designee, that it will pay to TVA, as DOE's agent, the associated cost penalties incurred due to the reduction in the amount of 5.5 to $6.5 \mathrm{mills}$ per kilowatt-hour at 100 percent load factor and one-time charge for each reduction of 400 per megawatt. Such advice shall be promptly confirmed by teletype or telegram. This surcharge applies to the period ending September 30, 1972, and is based on the 1400 MW minimum level referred to in paragraph 5 above.

(7) It is to be understood that the penalty payment to DOE by OVEC or EEI, as stated in paragraph 5 above, or to TVA as agent for DOE, as stated in paragraph 6 above, does not represent the total price of emergency power to the buyer. It does represent the payment to DOE necessary to avoid an increase in the unit cost of production when power is reduced. DOE would, of course, be relieved of its normal payments for power, to the extent that power is reduced. The total price to be paid by the buyer for such power would be a matter for determination between the parties concerned, recognizing all factors involved in each specific case including transmission arrangements, and subject to appropriate regulatory authority.

The electric power supplier contacted will call the Manager, Oak Ridge Operations Office (telephone 615-483-3611), or his designee, advising him of the request.

III. Actions by DOE

The Manager will initiate an appropriate implementation with the power supplier in accordance with the DOE power contracts and established DOE policy. 


\subsubsection{Mandate Electrical Energy Transfer, Interchange, or Transmission}

\subsubsection{Objective}

Provide for emergency electrical energy transfers when normal voluntary sharing agreements are ineffective.

\subsubsection{Concept of Operations}

The Federal Power Act authorizes DOE to order the interconnection and transfer of power if required to maintain reliable service. Upon its own initiative or at the request of an affected utility, such orders could be issued. See sections 32.60-32. G2 Tille 18 CFR. In the event of a natural gas shortage, a coordinated approach is envisioned to reduce electrical generation of natural gas-fired plants and replace the electrical energy via transfers from electrical generation capacity from areas operaling on more abundant fuel supplies. The ideal case would be one in which the same area that produced the replacement electrical energy also obtained the released natural gas, making the question of compensation more straightforward. In severe electrical energy shortages, it will be necessary to establish end use priority categories. Regional energy transfers would be made to conform to regional allocation plans.

\subsubsection{Benefits and Cost}

The benefits in terms of fuel can only be calculated with detailed analyses of each proposed transfer. Likewise, costs are difficult to determine. Beyond costs is the question of compensation and long run effects. Power systems do not maintain excess fuel slucks sufficient to produce additional electrical energy to serve a discant area for an extended period. The power generation that would be possible in the coal or nuclear dominant NERC regions (ECAR, MAIN, MARCA, \& SERC) and the capability to transfer excess power to heavy oil or gas using regions (MAAC, NPCC \& SWPP) has been assessed. It was estimated lhat during the full year 1980, transfers of available coal generated energy (after discounting for transmission energy losses) would displace $3,820,000$ MCF of gas and 45,871,000 bbls of oil.

The gas is equivalent to about 740,000 barrels of oil. Therefore, total displacement by power wheeling in the 9 eastern NERC regions is about 46,600,000 bbls/yr, or 125,000 bpd. This estimate is probably optimistic, based on NERC's estimate for new plant on-line schedules.1/ An update of this assessment is being made by NERC for the winter of 1977-78.

17:Source: National Electrical Reliability Councils, Study of Interregional Energy Transfers for the Year 1980, published in May 1976. 
In addition, $200 \mathrm{mw}$ of gas-fired capacity could - be obtained by closing existing circuits to the Texas intrastate system (ERCOT).

\subsubsection{Startup Plan}

Actions Taken

Research issues

Request NERC study

Actions Remaining

Establish operating committee

Develop specific plans

Obtain operation and reimbursement agreements
Agency

FEA

FPC

DOE

DOE

DOE
Completion Date

On going

August 11

November 1

December 1

December 15

3.3.3.5 Special Requiremerits and Documentation

Exhibit 3.2.14 Sections 32.60-32.62 Chapter 1 Title 18 CFR 
Exhibit 3.2 .14

FPC Order 520

Chapter L-Fedieral Power Commission

tion of the problem situation and resource limitations which require electric power and/or energy transfers: a showing that without additional power or energy transfers the applicant will be unable to maintain electric utility service required in the public interest after allowing for reductions by the receiving applicant of electric load and energy.demand that can be practicably accomplished consistent with public health, welfare and safety eonsiderations: a statement of the firm amounts of electric puwer and enelgy reccived from and dellvered to other systerns under existing

APPLICATIONS FOR COMMIJSION EMERGENCY AUTHORTF.ATTín PURSUANT TO EDOTION 202,(c) OF the Federai. Powen $\Lambda \mathrm{CT}$

$\$ 32.60$ Applicability of section 202 (c). Ecction 202(c) is applicable lo all enlilles whlch own or operate electric generation, transmission or distribution facllities, regardless of whether they are investor owned, publicly owned or cooperatively owned. All are subject to Commieslon emergency authority conferied by this Section. Initial Commission authorizations under 202(c) shall be for such durations and upon such terms and conditions as specified by the Commission. The Commission retains the right to cancel, modify or otherwise change a 202(c) suthorization at any time.

[Order 520. 39 FR. 420ก9, nor. 9,1074 ]

832.61 Application under 202 (c), Fil. ing Fecs, Exhibits and Other Adıninistrative Matters.

Every application under Section $202(0)$ of the Federal Pnwel Act shall be accompanted by the fee prescribed in Part 36 of this sub-chapter and shall set forth the following information:

(a) The exact legal name of the applicant and of all persons named as parties in the application:

(b) The name, title, and Post Office address of the person to whom correspondence in regard to the application shall be addressed:

(c) The state or states in which each entity named in the application operates, together with a brief description of the business of and territory, by counlles and states, served by such entity;

(d) The full title and address of any state regulatory agency which exrcises regulatory control of any type over the parties listed in the application;

(e) Reasons why the proposed transfors of power and/or energy will be in the public interest, to include: A descriprontracts (docignated by FTC Rale Schedule designations, where applicable), and a showing that additional power and energy cannot be purchased despite dlligent best elforts. inriluting the steps, if any, that have been taken to secure voluntary interconnections and energy transfers:

(f) A listing of proposed sources and amounts of power and cnergy recuested to be made available by Commission action. Applications for emergency authorization of the Commission shall be accompanied by a proposal of the applicant to compensate the generating or trans: mitting systems for the emergency scrvIces requested. These proposals shall be specific. Where the applicant proposes to compensate systeme for nmergeney yeivIces at rates and charges on file with the Cornnission pursuant to Part 35 of the Commission's Regulations Under the lederal Puwer Act, the application shall Irentify such rate echedulca by filing electric utility r.nत FPr. rato sohodulo designation;

(g) Description of proposed temporary electric power interconrection (s; , if any. showing proposed location, capacity, and type of emergency services requested. $\Lambda n$ elestrical nnentine diagram and a description of the necosenry material or equipment shail be included. If no temporary electric interconnection facilities are proposed, comparable information shall be supplied listing all existing interconneclion facllitiss and their electrical power transfer capacity and the type of emerency services requested:

(h) The:"e shall be filcd with the application and as a part thereof the follow'ing exhibits:

Exhibit A. A general or key map on a scale not greater than 33 miles to the Inch showlng (FPC Reclonal Maps prowerly marked nro deemed to be adequate), in separete colors. the territory served by each cntlly named in 
\$32.62 Tille 18-Conservation of Power, Water Resources

the appllcation, and the location of the $\mathrm{fa}$. cllities to be used for the generation and transmission of elcctric power and encrgy requested, indlcating on sald map the connec. tion points between systems.

$E x h$ ibit $B$. Statement o? the estimated construction costs of any proposed temporary Interconnection facilities required of the applicant to implement the 202(c) emergency power transfer. A further statement estimating the expected operations and maintenance costs on an annualized basis shall be Included.

(1) An original and six conformed coples of an application under $\$ \$ 32.60$ to 32.62 shall be filed and shall conform, in all respects, to the requirements of $8 \$ 1.15$ through 1.17 of this chapter. Each entity designated as a potential source of cmergency assistance in an application filed pursuant to this subsection Interested State regulatory commissions having jurisdiction over the "potential source" and/or transmitting utilities, and the Regional Reliability Council for the applicant's area shall, at the time of application, be served with a copy of the application by the applicant:

(j) The porsons so desionated and served by an applicant shall submit their answers to the Commisison and serve coples thereof on the interested State regulatory commissions and the RegIonal Reliability Council within 10 calendar days of the date of filing of the application unless otherwise directed by the Commission's Secretary, and as part threof, they shall analyze the impact of the required power and energy transfers upon their capabilities to provide for loads on their own systems; and

(k) A report to the Commission shall be rendered by the applicant not later than 10 days following the end of each month after a 202(c) authorization is granted. Copies thereof shall simultaneously be served on the interested State regulatory commisisons and the Regional Reliability Council. This report shall include the amounts of power and encrgy received each day, the name of the suppller, preliminary cstimates of the assoclated costs and any other pertinent information requested by the Commission's Secretary.

(1) The Commission may require additional information when it appears to be pertinent in a particular case. Sce particularly \$ 32.62 (d) and (e).

IOrder 520, 39 FR 42909, Dec. 9, 1974, as amanded by Order 520-A, 40 FR 6145. Feb. 4. 1975]
\$ 32.62 Energencies Rolalod to Inade. quate Supplies of Furl or linergy for Electric ficnerating Plants.

(a) Applicability. (1) This subsection of the Commission Regulations applies specifically to applications covering claimed emergencies that result from a lack of the necessary fuel or energy supplies for electric generating plants. The provisions of this subsection in no way restrict the Commission's broader authority to act upon any set of circumstances in which it deems that an emergency exists based upon the conditions listed In section 202(c) of the Federal Power Act:

(2) This subsection shall be applicable for use only by applicant electric systems having electric generating equipment in normal system use whose operation will be adversely affected by a fuel or energy shortage emergency:

(3) Applications required to be filed under this $\$ 32.62$, shall, nevertheless, set forth all data as required in $\$ 32.61$.

(b) Additional Application Information. Applications for emergency authortzation by the Commission by reason of a claimed emergency due to inadequate supplies of fuel or energy shall be accompanied by the following:

(1) Detailed statement of the amounts of firm electric power and energy received and delivered to other systems under exlisting contracts for the 60 day period preceding the application (designated by FPC Rate Schedulc, where applicable).

(c) Guidelines Defining Inadequate Fuel or Energy Supply. An inadequate utility system fuel inventory or energy supply is a matter of managerial and cngineering judgment. Fuels in stock, fuels enroute, transportation time and constralnts on available storage facilltles and other factors must be considered in determining an inadequate fuel inventory. For guldeline purposes, a system may be consldered to have an inadequate fuel or energy supply capability when one or more of the following condillons exist and the projected energy deficiency upon the applicant's system-without emergency action by this Commissionwill equal or exceed 10 percent of the applicant's then normal daily net energy for load. or will cause applicant to be unable to meet its normal peak load requirem 2 ts based upon use of all of th otherwise available resources, and such energy deficlency will require the appltcant to drop laads to ultimato customers; 
(1) System coal stocks are reduced to 30 da.'s (or less: of normal burn days and a continued downward trend in stocks is projected:

(2) System residual oil stocks are reduced to 15 days (or less) of normal burn days and a continued downward trend in stocks is projected:

(3) System distillate oil stocks are reduced to 15 days (or less) of normal burn days and $\bar{a}$ continued downward trend In stocks is projected:

(4) System natural gas dellveries which cannot be replaced by alternate fuels have been or will be reduced 20 percent below normal requirements and no improvement in natural ge.s deliverles is projcotcd within Jo days":

(5) Delays in nuclear fuel dellverfes will exlend a scheduled refueling shutdown by more than 30 days; and

(6) Water supplies required for power generation have been or will be reduced 20 perocnt bclow normal requirentits and isu linurovement in water supplies is projected within 30 days.

The use of the prescribed criteria do not preclude an applicant from seeking to claim and support an emergency when Its stocks of fuel or water exceed the forezoing amounts.

(d) Factors to be Considered by the Commission in Declaring cn Emergency. Among other factors, the Commlssion, in evaluating an application for cmergency power and energy transfers under this $\$ 32.62$ will give consideration to the impact of the power and energy transfers on the supplying and transmitting systems. While the conditions of an emergency can vary grently and. therefore, the Commission cannot be restricted in making decisions that a re best sulted to the circumstances, it contemphates that emergency power or energy transfers desirab!y should not resuit in the dropping of loads of uitimate customers of the supplying utility systems. However, data avallable to the Commtssion Indicate that voluntary conservation and utillty-initiated mensures can effect significant reductlons in load and energy reculrements and consideration of a reasonable and equitable level of

Criteris governing thls Commission's btabutory dulles und responsibllitles arising under the Natural Ons Act, 15 Q.S.C. 7J7(n) et $80 \mathrm{C}_{4}$ must be referred to when conslderIng this Commision's nnt,ural gus alloca. tion program, and not the provtsions eet for:h hereln with respect to $202(\mathrm{c})$ of the Federal Power Act. such reductions by the supplying system will not be excluded from the Commission's review. The Commission recognizes that power pools and existing industry relationships are a basic tool in resolving energy shortages and the Commission will review the implementation of emergency procedures of individual pools and applicant systems in determining whether to invoke its emergenc; powers.

(e) Rates and Charges. The applicant and generating or transmitting systems from whom emergency service is requested to meet inadequate supplies of fuel or energy, are encouraged to utilize the rates and charges contained in exlsulug rate schedulcs on file with the Commission, or to negotiate mutually satisfactory rates for the proposed transaction. In the event the Commission determines that an emergency exists under Section $202(\mathrm{c})$, and the parties are unable to agree on the terms of the servico to be rendered and/or the rates to be charged, the Commission shall prescribe the conditions of service and the rates and charges. Moreover, the Commisston may proscribc different rates, lemis and conditions than those set forth in any agreement of the parties. In order that the parties may be guided in their negotiations as to the rate form and rate level ihat the Commission may prescribe, should the parties be unable to agree, the following costing methods shall be utilized by the Commission, depending upon the service to be rendered:

(1) Fully allocated costs. If the serv. Ice to be rendered has characteristics of firm service similar to that rendered by the supplier to its other customers, the generating and transmitting systems shall each be ontitlod to reoover the following costs:

(1) An allocable portion of Investment costs of its respective production plant, including return on investment, depreciation, income taxes, property and other taxes related to plant investment and Insuranoc;

(1i) An allocable portion of investment costs of its respective transmission plant, including return on investment, depreciation, income taxes, property and other taxes related to plant invectment and insurance:

(iil) incremental cost assuclaled with Its respcctive ceneration of emergency service to meet inadequate supplies of fuel or energy. Incremental costs shall mean such overating and maintenance 


\section{$\$ 32,62$ Title 18-Conservation of Power, Water Resources}

expenses Incurred that would not have been otherwise incurred if such service had not been furnished. Such expenses shall include the incremental expenses Incurred in the production of the encrgy so furnished, including incremental fuel expense (i.e., replacement fuel costs), Incremental operating labor and supplies, incremental maintenance, labor and suppplies, and incremental adminIstrative and general expenses; and

(iv) Incremental costs incurred in its respective transmission of emergency service to meet inadecuate supplies of fuel or energy, including incremental operatIng labor and supplles, incremental maintenance, labor and supplies, incremental administrative and general expenses, transmission network losses which shall Include incremental (replacement) fuel expense, if any. in generating such losses, and any other related costs.

(2) Incremental costs plus additional compensation. If the service to be rendered is non-firm in nature, the generatIng and transmitting systems shall each be entitled to recover their respective Incremental costs plus some additional reasonable compensation, as follows:

(1) Incremental costs associated with their respective generation of emergency service to meet inadequate supplies of fuel or energy. Incremental costs shall mean such operating and maintenance expenses incurred that rould not have been otherwise incurred if such service had not been furnished. Such expenses shall include the incremental expenses incurred in the production of the energy so furnished. including incremental fuel expense (i.e., replacement fuel cost), incremental operating labor and supplies, Incremental maintenance labor and supplies, and incremental administrative and general expense:

(ii) the incremental costs incurred in its respective transmission of emergency service to meet inadequate supplies of fuel or energy, including incremental operating labor and supplics, incremental maintenance labor and suppljes, incremental administrative and general expenses, transmission network losses which shall include incremental (replacement) fucl expense, if any, in generating such losses, and any other related costs; and

(III) as additional compensation to the gencrating and transmitting systems for the utllization of their respective facilities for the generation and transmission of such emergency service to meet inade- quate supplles of fuel or energy, each of these systems shall be permitted some additional amount to compensate the supplier (A) for any and all risk associated with his need to replace the fucl burned for purposes of rendering the service: (B) for revenue reductions occasioned by any reduction in services to the supplicr's own customers which would otherwise be applied to cover the supplier's costs associated with the services foregone: and (C) for costs associated with the environmental degradation resulting from the additional operation of the generating plants of the supplying system. In addition, a further component of such additional amount may be warranted where there is imprudence supported by evidence that the purchaser's emergency could have been eliminated or alleviated by actions that he could reasonably have been expected to take under the circumstances. In no case should the sum of these payments exceed the fully allocated costs of the supplying and transmitting systems.

(3) Share the savings. Where the parties seek to employ a sware-the-savings method for non-firm service, the following factors shall be taken into account:

(i) Incremental costs of generation, including:

(A) Incremental fuel costs for service rendered primarily from thermal generating sources, or, as in the Paciflc Northwest. the incremental cost of generation from hydro-based operations shall be deemed to approximate the rate for dump hydro energy;

(B) Start-up costs; and

(C) Incremental operation, maintenance and administrative costs.

(ii). Decremental costs of generation replaced on the receiving system under conditions obtaining immediately prior to the onset of the shortage.

The price for fuel emergcnoy servlce. would be equal to the supplier's incremental generation costs, plus one-half of the difference between the costs to the purchaser (the supplier's incremental cost plus the sum of the transmission charges, by intermediate transmitting systems) and the purchaser's decremental costs.

(4) The foregoing do not preclude parties from proposing other methods. e.g., return-in-kind, or barter. [Order 520, 39 FR 42909, Dec. 8. 1974] 


\subsubsection{Modify Coal Conversion Orders}

\subsubsection{Objective}

Permit installations operating under mandatory coal conversion orders to switch temporarily to an alternate fuel.

\subsubsection{Concept of Operations}

Under the Energy Supply and Environmental Coordination Act (ESECA), DOE has ordered a number of fuel-burning installations to burn coal as their primary or only fuel. A coal conversion order is not mandatory, however, until an environmental study has been completed and a Notice of Effectivcness has been issued. At this time, eight coal conversion orders have gone into effect. A maximum of twenty fuel-burning installations may be operating under mandatory coal conversion orders by this winter.

Under procedures contained in Subpart $\mathrm{J}$ of DOE'S Coal Conversion Regulations, any installation operating under a coal conversion order can request a modification of that order. Upun recelpt of such a request, DOE will evaluate the circumstances and, if appropriate, modify the order permitting the installation to switch temporarily to an alternate fuel.

In the event of a coal supply interruption, coalburning installations normally maintain sufficient stocks to permit use of this modification procedure without disruption lo nurmal operations. However, it is also possible that a breakdown in coal handling equipment (this winter or any other time) could necessitate an immediate switch to an alternate fuel. Amendments to the Coal Conversion Regulations, sche... duled for release in November, contain an interpretation of subpart $J$ whereby coal burning installations can affect an emergency switch to an alternate fuel.

\subsubsection{Benefit and Cost.}

Under this measure installations operating under coal conversion orders can supplement their coal stocks with alternate fuels. In the event of a severe winter, however, it is likely that alternate fuels would also be in short supply.

\subsubsection{Startup Plan}

Actions Taken

Amendments to Coal Conversion Rejulations published for comment
Agency

DOE
Completion Date November 1977 
Actions Remaining

Finalize Amendments

Request modification of coal conversion order

Review request and issue modification
Agency

DOE

Coal-burning installation

DOE
Completion Date

December 1977

As needed

Upon receipt

3.3.4.5 Special Requirements

Issue Amendments to Coal Conversion Regulations

\subsubsection{Documentation}

Exhibit 3.3.4 Coal Conversion Regulations,

Subpart $J$ - Modification of Rescission of Prohibition Orders and Construction Orders. 


\subsection{Propane}

The winter heating season is usually a time of peak demand for traditional users of propane - primarily homeowners and agricultural users. In the event of severe winter weather conditions, nontraditional industrial users also place heavy demands on available propane stocks to replace curtailed natural gas supplies.

The winter increase in demand for propane is frequently aggravated by the limitations of the propane distribution system. The preferred method of transporting propane is by pipeline to local terminals and then by truck to the end user. Rail shipments also represent a significant means of transporting propane from storage point to consumer. In a period of extremely heavy demand, it is impossible to move propane supplies in large enough quantities to satisfy demand.

Spot shortages of propane in local areas are normally the result of an inadequate propane distribution system rather than a shortage in overall supplies. A prolonged period of cold weather can be expected to cause depletion of local propane stocks, reports of homes and farms without fuel, and increased demand for propane from industrial users of natural gas.

There is very little that can be done on a short-term basis 'to alleviale any propane shortages which might accompany extremely cold weather this winter. The plan envisions that domestic propane supplies will be supplemented with imported LPG whenever possible. Here again, however, the value of this extra supply is constrained by the capacity of the distribution network.

The other two propane measures contained in this plan are designed to ensure that, in an emergency, the available supplies will be directed to traditional users to protect life and property.

\subsubsection{Clarify DOE Position on Propane Imports}

\subsubsection{Objective}

The objective of this measure is to assure propane importers that DOE supports the importation of LPG to supplement scarce domestic propane supplies for high priority emergency use this winter.

\subsubsection{Concept of Operations}

Based on comments made by members of the LP Gas Industry Advisory Committee on June 28, 1977, a yeneral impression existed within the industry that DOE (then FEA) opposed any increase in imports of fuel supplies. The committee members indicated that a clarification of DOE's position on propane imports for the winter heating season was needed. 
On September 2, 1977, FEA Administrator 0'Leary sent a personal letter to each of the major propane importers stating that the Federal Bovernment supports increased LPG imports to meet winter demand for propane for high priority uses.

\subsubsection{Benefit and Cost}

According to a report prepared by the DOE LP Gas Industry Advisory Committee, the exportable surplus of LPG from producing countries during 1977 equals 444,716 barrels per calendar day (BPCD). This is an increase of 105,156 BPCD over 1976. Although other consuming countries also import LPG, it is likely that the United. States could import a significant portion of the total surplus. However the availability of propane tanker ships, the capacity of the propane port facilities for unloading, and the domestic distribution system in the United States are important factors that limit the amount of LPG which can actually be imported.

On the average, imported LPG costs $\$ .07-.10$ per gallon more than domestic propane. Under DOE's proposed propane regulations, suppliers would not pass the higher cost of imported surplus LPG directly to industrial or gas utility consumer but could roll-in the higher costs of imported NGL's provided to other classes of customers.

\subsubsection{Startup Plan}

\begin{tabular}{lll} 
Actions Taken & Agency & Completion Date \\
$\begin{array}{l}\text { Letter sent to major propane } \\
\text { importers }\end{array}$ & DOE & September 2, 1977 \\
Actions Remaining & & \\
\hline
\end{tabular}

None

3.4.1.5 Special Requirements

None

3.4.1.6 Documentation

Exhibit 3.4.1 Letter to propane importers from FEA Administrator 0'Leary 


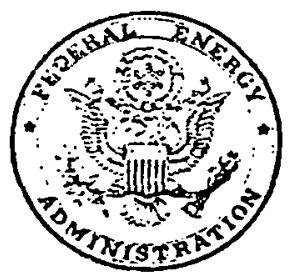

EXHIBIT 3.4 .1

FEDERAL ENERGY :ADMINISTRATION

WASHINGTON, D.C. 20461

September 2, 1977

OFFICE OF THE ADMINISTRATOR

Addressee

Dear $M r$.

$:$

The Federal Energy Administration (FEA) is presently developing contingency plans for mecting emergency needs during the next winter in the event of severe weather or fliel chortages. It lids cume to our attention that some confusion exists with respect to FEA policy regarding propane imports for the near term.

FEA recognizes that increased imports of propane may be necessary to prevent or alleviate supply shortfalls which could result from a colder-than-normal winter in 1977-78. The past winter saw a severe drawdown of propane stocks to meet the demand of traditional users and as an alternate fuel to curtailed natural gas. A recent report of the FEA I.PG Advisory Committee noted that increasing propane imports is a feasible action from the standpoint of worldwide supply and U.S. port and product distribution facilities.

The FEA regulatory provisions on the import of non-Canadian propane impose few restrictions on suppliex-importers. Imports may be used to improve your allocation fraction (if less than 1.0); distributed for industrial use in excess of the base period use limitation (if your allociation fraction equals or exceeds 1.0); or sold as surpl.us product. Although the pricing provisions for each method of distribution may vary, the import of non-Canadian propane is an action which may be taken to increase available supply to meet a greater demand.

Additional information on the specific regulations which govern this matter can be obtained from the FEA Office of Regulatory Programs. Please let me know if we can be of further assistance.

Sincerely,

$$
/ s /
$$

John F. O'Leary

Administrator 


\subsubsection{Enforce Restrictions on Use of Propane as Alternate Fuel}

\subsubsection{Objective}

The objective of this measure is to emphasize strict adherence to prescribed guidelines by regional operations personnel in their evaluation of applications for assignment or adjustment of propane allocation for industrial use.

\subsubsection{Concept of Operations}

Applications from curtailed industrial users of natural gas for assignment or increase of a propane allocation entitlement during severe winter weather conditions could have a significant impact on the level of available supplies for traditional propane users. The peak demand for natural gas coincides with the peak demand for propane. Thus, the issuance of assignment or adjustment orders for propane as an alternate fuel frequently results in shortages of available propane supplies in local market areas.

Section $211.12(h)$ of the Federal Energy Regulations specifies the procedures under which a fuel user whose energy supplies have been or may be curtailed can apply to DOE for assignment or adjustment of an allocation for an alternate fuel.

I tem $2(k)$ of the Guidelines for this section (Exhibit 3.4.2) specifies the criteria which should be followed in evaluating requests for assignment or adjustment of a propane allocation for industrial use. Specifically, the most important industrial use is "as a process or plant protection fuel," while "other industrial uses, such as for boiler fuel or space heating, are considered to be less critical uses of propane."

In October 1977, the Acting Assiștant Administrator for Fuels Regulation of the Economic Regulatory Administration sent a memorandum to the Regional Directors for Fuels Regulation emphasizing the importance of strict adherence to Section 211.12(h) and to item $2(k)$ of the Guidelines in evaluating applications for propane assignments or adjustments from curtailed industrial users of natural gas. (Exhibit 3.4.3)

\subsubsection{Benefit and Cost}

Strict adherence to the Guidelines for Section 211.12(h) will ensure that propane is not used as an alternate fuel for industrial boiler fuel and space heating purposes when it is needed by traditional users to protect life and property. The principal drawback is that some industrial natural gas users that have been curtailed could be forced to shut down if they are unable to obtain alternate fuel supplies. This would impact the economy in the form of increased unemployment and a loss in production. 


\subsubsection{Startup PIan}

Actions Remaining

Agency

Completion Date

None

Actions Taken

Agency

Completion Date

Memorandum set to

DOE

October 1977

regional directors

for fuels regulation

3.4.2.5 Special Requirements

None

3.4.2.6 Documentation

Exhibit 3.4.2 Item $2(k)$ of Guidelines for Section $211.12(h)$ of Federal Energy Regulations.

Exhibit 3.4.3 Memorandum, Subject: Curtaịment Assignments of Propane for "Less Critical Uses". 
curtailed as specified in $10 \mathrm{CF} \dot{R} 211.12(\mathrm{~h})$ shall be consistent with the provisions of 10 CFR 211.12(e), 211.12(f) and 211.13.

(i) End-users and wholesale purchaser-consumers should be advised of the availability of the State set-aside to meet hardship and emergency requirements as provided by 10 CFR 211.17.

(j) In evaluating an applicant's requirements for the purpose of assignment or adjusting its base period use, each use that the applicant has for the fuel shculd be separately assessed in accordance with appropriate allocation levels in determining whether and the extent to which the assignment or adjustment can be made in light of prevailing supply conditions and the effect such assignments and adjustments would have upon other purchasers of a supplier.

(k) FEA anticipates that most assignments and adjustments for propane and butane will be under allocation levels for industrial uses. The most important of these uses is industrial use as a process or plant protection fuel as defined by 10 CFR 211.82. Other industrial uses, such as use for boiler fuel or space heating, are considered to be less critical uses of propane. In its assessment of applications for such uses, FEA will consider the ability of applicants to convert to an energy system which is fueled by an energy source other than propane, butane or natural gas

(1) In general, it is not FEA's policy to grent applications for assignments and adjustments of propane and butane to gas utilities experiencing curtailment since gas utilities are ahle themselves to curtail gas service to industrial end-users who possess an alternate fuel capability.

(2) FEA may grant assignments or adjustments of propane or butane to industrial users who have no facilities for use of propane or butane and who propose to transfer the propane or butane to a gas utility for storage, gasification and transmission back to the industrial user in gaseous form on a BTU equivalent basis. This procedure may be followed only in those cases where the industrial user bears the entire cost of the product and any charges for its storage, gasification and transmission; where there will be no adverse effects on the gas utility's other customers; where the industrial user has no facilities for using a fuel other than pipeline gas; and where this procedure is consistent with all applicable Federal and State laws, regulations and orders. State regulatory practices, 
MEMORANDUM FOR REGIONAT DIRECTORS FOR FUELS REGULATION

FROM : $\quad$ BARTON HOUSE

ECONOMIC REGULATORY ADMINISTRATION

SUBJECT: $\quad$ CURTAILMENT ASSIGNMENTS OF PROPANE FOR LESS CRITICAL USES

The purpose of this memorandum is to emphasize the proper application of the guidelines for $211.12(\mathrm{~h})$ assignment/ adjustment actions.

Applications from curtailed industrial users of natural gas for assignment/adjustment of an allocation entitlement for propane during severe winter weather conditions represent a potentially significant impact on available supplies for traditional users. The peak demand for natural gas coincides with the peak demand for propane so that assignment/ adjustment orders for propane as an alternate fuel frequently result in shortages of available supplies in local market areas. To a great extent these shortages are txansportation related, in that the capability to move increased quantities of propane during periods nf peak demand is marginal.

Regional offices must carefully evaluate each application from an industrial user. The guidelines issued for processing $211.12(\mathrm{~h})$ actions should be follnwer in all instances unlcas there are compeliing reasons to the contrary. See supplemental guidance in memo of October 6, 1976, from Gorman C. Smith, subject: National office Approval of Assignments and Adjustments of Propane to Curtailed Users of Natural.Gas. of particular concern during periods of peak demand for propane is the proper consideration by Regional offices of the provisions of paragraphs $2(j)$ and $(k)$ of the guidelines. Each industrial use of propane must be identified and evaluated. Obviously, the most important of these uses is as a process or plant protection fuel. Other industrial uses, such as for boiler fuel or space heating, are considered to be less critical uses of propane. 
Given conditions of severe winter weather and peak demand for propane from traditional-users (principally homeowners and agriculture), Regional offices may choose to withhold assignment/adjustment actions for less critical uses. In fact, where life and property are threatened, assignment/ adjustment actions. for use of propane as a process fuel may justifiably be withheld. In either case, Regional Offices should maintain close liaison with state energy offices for input on the impact of granting or withholding such actions. 


\subsubsection{Establish Emergency Method of Propane Allocation}

\subsubsection{Objective}

The objective of this measure is to support the efforts of propane suppliers and distributors to protect life and property by upgrading the allocation level for such uses during an energy emergency.

\subsubsection{Concept of Operations}

Last winter, in responding to the crisis situation caused by severe spot shortages of propane, FEA issued Special Rule No. 1 , Emergency Allocation Levels and Suppliers Method of Allocation, and Special Ruie No. 2, Fmergency Proccdures for Redirer:tion of Propanc for Iligh Priurlty Use ur Inventory Accumulation.

Since last winter DOE has proposed a number of revisions to the propane allocation regulations. Among these are Guidelines for the Allocation of Propane and Other NGLs for Gas Utility and Gas Transmission Company Use, published in the Federal Register on July 29, 1977. A revised Subpart D was also published for comment on August 15,1977.

However, none of these proposals provides a fully workable regulatory mechanism to protect life and property during severe winter weather conditions. The current and proposed priority users (agriculture and defense) are not subject to an allocation fraction. All other users share the remlining supply on the basis of the same allocation fraction (although at different allocation levels). This approach does not serve to protect 1 ife and property during severe winter weather conditions.

DOE is considering several approaches for resolution of this problem including placing a floor on the volume of propane which will be available to residential users in the event of shortages. A new Special Rule can be implemented by DOE on a state-by-state basis in the event of a severe emergency.

\subsubsection{Benefits and Cost}

This measure will bridge the gap between current regulatory provislons governing the allocation of propane and the actions which suppliers and distributors must take to protect life and property in crisis conditions. It will also give the State Energy office maximum flexibility to respond to emergency situations.

Some industrial users of propane could be forced to shut down if they are unable to obtain alternate fuel supplies. This would impact the economy in the form of increased unemployment and a loss in production. 


\subsubsection{Startup Plan}

Actions Taken

None

Actions Remaining

Amend residential allocation level

Finalize Special Rule

Request implementation
Agency

Agency

DOE

DOE

Governors
Completion Date

Completion Date

December 15, 1977

At time of emergency

At time of emergency

3.4.3.5 Special Requirements

None

3.4.3.6 Documentation

None 


\subsection{Petroleum}

The incremental winter demand for fuel oil by traditional users is related to the severity and duration of winter weather. Demand by non-traditional users (i.e., industrial users) is also related to the weather but is governed primarily by the extent of natural gas curtailments and the resulting demand for fuel oil as an alternate source of energy.

Last winter's performance can be accepted as an indication of the capability of the industry to move increased quantities of fuel oils to meet extreme demand (albeit at some increased costs). Overall supplies of fuel oil are predicted to be adequate for next winter, and industrial storage is high. Reenactment of a middle distillate state set-aside for the heating season would help to relieve local emergency-hardship situations.

In contrast to the spot shortages associated with extremely cold weather, a major disruption of petroleum imports could cause a severe nationwide shortage of petroleum products, particularly gasoline. Therefore, the petroleum measures section also includes drastic measures which would be considered only in the event of a severe supply interruption. Most of these involve implementation of standby mechanisms and programs authorized by Congress, including drawdown of strategic reserves and reinstatement of price and al location regulations.

In addition to the measures described in this section, DOE will establish a middle distillate price monitoring system, which will compare current prices to an index price, to determine if reimposition of price controls should be considered. 


\subsubsection{Implement Middle Distillate State Set-Aside Program}

\subsubsection{Objective}

The objective of this measure is to provide a tool the states can use to relieve emergency shortages of middle distillates this winter.

\subsubsection{Concept of Operations}

On August 5, 1976, FEA issued Special Rule No. 3 which provided special set-aside procedures for middle distillates to be administered by state energy offices and FEA's regional offices. Special Rule No. 3 expired on March 31, 1977.

The set-aside program was extremely well received while it was in operation. Many marketers have requested that DOE reestablish the special set-aside procedures this winter. All 45 states which responded to a WEEP Task Force questionnaire indicated that the program should be reinstituted for the coming winter.

In November, 1977, DOE enacted the Special Rule reestablishing the middle distillate state set-aside this winter. Special Rule No. 5 provides for a set-aside to be administered by the state energy offices and DOE's regional offices from November 1977, through March 31, 1978. The Rule permits marketers who have made diligent though unsuccessful efforts to obtain supplies to be assigned as much as their previously authorized base period use from the special set-aside. These assignments may be made for periods of up to 90 days or .longer if required to preclude hardships to consumers. The Rule allows assignments to be made directly to consumers under the same hardship criteria that existed previously for middle distillates in the state set-aside program.

The set-aside for each prime supplier constitutes four percent of its total supply of middle distillates for the particular month to be sold into the distribution system of a state for consumption in that state.

\subsubsection{Benefit and Cost}

The principal benefit of the middle distillate state set-aside is to furnish a source of supply for marketers and end users who do not have access to other supplies. The program can be a particularly effective tool to relieve emergency situations during the winter months. 
The principal cost of the program is the administrative workload and recordkeeping costs for state energy offices and $\mathrm{DOE}$ regional offices. In a severe shortage, a state may have to assign several full-time persons to administer the program.

\subsubsection{Startup Plan}

Actions Taken

Al1 states polled regarding. their opinion on reinstitution

of middle distillate set-aside

Issue addressed by NGA Winter . NGA

Emergency Task Force

Notice of Proposed Rulemaking

Publ ished. in Federal Register

for comment

Public hearing held

Finàl rulemaking
Agency

DOE

DOE

DOE

DOE
Completion Date

August 1, 1977

August 5, 1977

October 5, 1977

October $27, .1977$

November 14, 1977

\subsubsection{Special Requirements}

None

\subsubsection{Documentation}

Nutice of Proposed Rulemaking, Uctober 5, 1977.

Finàl Rule, November 14, 1977 
EXHIBIT 3.5 .1

\begin{abstract}
[3128-01]
FEDERAL ENERGY

ADMINISTRATION

[ 10 CFR Part 211]

SPECIAL SET-ASIDE PROCEDURES

FOR MIDDLE DISTILLATES

Proposed Rulemaking and Public Hearing

AGENCY: Federal Energy Administration.

ACTION: Notlce of Proposed Rulemaking and Public Hearing.

SUMMARY: FEA proposes to amend the Mandatory Petroleum Allocation Regulations to relnstate, by the adoption of a Special Rule No. 5, a set-aside procedure for middle distillates to be admin. istered by the State Energy Offices and FEA's Regional Offices for the vertod November 1977 through March 1978. The proposal would permit wholesale purchaser-consumers and end-users who have made unsuccessful efforts to obtain supplies for an emergency or hardship to acquire that volume required to meet their certifled current requirements.
\end{abstract}

DATES: Comments by October 21, 1977; Requests to speak by October 14, 1977; Hearing date: October 21, 1977.

ADDRESSES: Comments and requests to speak to: Executive Communications, Room 3317, Federal Energy Administration, Box PT, 12th and Fennsylvania Avenue NW., Washington, D.C. 20461: Hearing location: Room 2015, $2000 \mathrm{Ma}$ Street NW., Washington. D.C. 20461.

FOR FURTHER INFORMATION CONTACT:

Ed Vilade (Media Relations), 12th and Pennsylvania Ave. NW.. Room 3104. Washington, D.C. 20161 (202-566-! 9833).

Gerald P. Emmer. (Regulatory Programs), 2000 Mr street, NW., Room 2304, Washington, D.C. 20461, (202254-7200). 
Michael Palge. (Office of the General Counsel), 12th and Pennsylvania Ave., NW., Room 5134, Washington. D.C. 20461. (202-566-9565).

SUPPLEMENTARY INFORMATYON:

I. Background.

II. State Set-Aside Proposal.

III. Comment Procedures.

I. BACKGROUND

DEREGULATION OF MIDDLE DISTILLATES

On June 15, 1976 FEA issued and submitted to the Congress two separate amendments which provided for the exemption of middle distillates from allocation and price controls. These amendments became effective July 1, 1976.

In response to concerns expressed by some members of Congress, FEA informed the Congress that a set-aside procedure administered by FEA's Regional Offices would be established before the end of July 1976 to operate to Insure that no marketer would lose its supply source without adequate time to arrange a new supplier during the transitional period following removal of controls.

\section{STATE SET-ASTEE PROCEDURE ADOPTED}

On July 9. 1976, FEA issued a notice of proposed rulemaking and public hearing (41 FrR 28797. July 13, 1976) concerning establishment of a special set-aside procedure for middle distillates to be in effect from August 1976 through March 1977.

Because this new set-aside program could not be implemented before August 1. 1976. FEA adopted an interim rule (Special Rule No. 2 to Subpart A) on July 1, 1976 which continued the operation of the then existing State set-aside program in a modified form for one month following the exemption.

On August 5, 1976 (41 FR 33881, August 11, 1976), FEA adopted Special Rule No. 3 which provided that, notwithstanding the exemption of middle distillates from controls, a special set-aside procedure for middle distillates would be in effect for the months of August 1976 through March 1977. Under these procedures State Offices were enabled to make assignments to marketers which could demonstrate an inability to obtain adequate supplies of middle distillates after reasonable efforts in this regard and directly to conusumers who could meet the ame hardship criterla that were in efiect for the State set-aside program.

HEARSNCS ON FORTHER ACTION WITH REGARD TO NIDDLE DISTILLATES

On May 26, 1977. FEA issued a Fur: her Notice of Proposed Rulemaking and Public Hearing to provlde an opportu:ity for receipt of comments and testlmusy on the manner in which the FEA aiddle distillate price monitoring system had operated during the past heating rason and on what action, if any, should ie taken by FEA with respect to middle istillates during the 1977-1978 winter. in the perfod July 11, through 15. 1977, -EA held reglonal henrings in the folowing citles: Boston, New York, Chl- cago, Seattle and Atlanta. FEA held a national publlc hearing in Washington. D.C. from August 2, 1977 through August 4,1977 . On the third day of the national hcaring presentations were made by representatives of consumers groups, which FEA funded to promote the acquisition of the technical assistance necessary for the proper preparation of their views.

\section{State Set-Astoe Proposar.}

FEA's review of the public comments recelved on the State set-aside procedures revealed strong support for this program among the states, consumer groups and trade associatlons, which vlewed the set-aside as an effective device to address emergency situations such as occurred in the 1976-77 winter. State governments argued that since State Energy Offices are in existence, such offlces are most awere of local conditions and can move most quickly to get supplies to those who are experiencing an emergency or hardship situation. Refiners stated that the set-aside program only provlded another level of bureaucracy and inhibited the transfer of heating of from one area to another. Moreover, refiners stated that the set-aside procedures had been used sparsely during the 1976-77 winter. FEA has carefully analyzed and evaluated these comments and has decided that the set-aside procedures represent an important means of Insuring adequate supplies of middle disttllates to consumers to meet emergency and hardship situations.

F'EA's initial determination is that adoption of a state set-aside for the 1977-78 winter is necessary to attain. and is consistent with, the objectlves spectfled in section 4(b) (1) of the Emergency Petroleum Allocation Act of 1973, as amended ("EPAA"). In particular, FEA believes that such a regulation would further the ohjectives set. forth in seotion $4(b)$ (1) of the EPAA by promoting public health, safety and welfare (including maintenance of residential heating for individual homes, apartments and simvar occupied dwelling units) and the equitable distritution of refined petroleum products among all regions and areas of the United States, and sectors of the petroleum industry, and among all users. In relmposing the State set-aside for middle distillates, FEA would be taking action under section $12(f)$ of the EPAA, which permits the President to prescribe such a regulation upon $\mathrm{s}$ determicialiun by him that such regulation is necessary to attain, and is consistent with, the objectives specified in section (b) (1) of the EPAA.

FEA proposes to reinstate a set-aside program by adopting a new Special Rule No. 5 for Subpart A of Part 211. The special procedures proposed hereby provide that, notwithstanding the exemption of middle distillates from controls, a special set-aside progtam for middle distlllates would be in effect from November 1, 1977 to March 31, 1978 so as to permit assignments to marketers and consumers by Statc Enerby Omices or by the appropriate FEA Regional Office a State Energy Office declines adminl tration of the procedures. Within $10 \mathrm{da}$ : after the effective date of this Special Rule, each suppller would designate for each State within which the supplier operates as a prime suppller a representative who would act on behalf of the prime supplier with regard to these special procedures. The set-aside would constitute lour (4) percent of a prime suppller's estimated portion of 1ts total supply of middle distillates for the particular month which wlll be sold into the distrlbution system of the State (for consumption therein). The set-aside volume for a particular month cannot be accumulated or deferred and may be released totally or partially at any time during the month by order of the State Energy Office. These volumes would be avallable for assignments to wholesale purchaserconsumcrs and end-users who have made unsuccessful efforts to obtain supplies for an emergency or hardship. Such assignments would be limited to that volume required to meet certifled current requirements and conditioned upon demonstration of the same hardship criterta that were in effect for the State set-aside program. Assignments could also be made to wholesale purchaser-resellers who are unable to obtain a suffictent volume of product to meet the emergency and hardship needs of those wholesale purchaser-consumers and end-users with whom the wholesale purchaser-reseller had a supplier/purchaser relationship on November 1. 1977. Application for these volumes would be made to the appropriate State Energy Office which would approve or disapprove the application. If the State Energy Office approved the application, it would assign a prime supplier to fumish the applicant an amount from the set-aside. The State Energy offco would icouo both the apjilibuit and the representative of the prime supplier a document authorizing such assignment. This document would entitle the applicant to receive the assigned volume from any convenient local distributor of the prime supplfer from which the set-aside assignment, had been made. Such document would expire ten days after issuance unless it had been presented to the prime supplier or a designated local dis. tributor of the prime supplier.

PROPOSED MODIFICATION OF THE CATEGORIES OF ELIGIBLE RECIPIENTS

ihe proposed operation of the state set-aside under the Special Rule differs in only one aspect from the operation of Special Rule No. 3 during the last heating season. FEA adopted Special Rule No. 3 to Insure that during the transitional pcriod follnwing removal of controle on middie distlllates no marketer would lose its supply source without adequate time to secure a new supplier. To prevent supply disruptions, Special Rule No. ? further provided a procedure througl which a wholesale purchaser-reselle could obtain a volume of middle distlllates equal to its base perlod use of mid- 
dle distillates as determined under -ibparts. A and G of Part 211. Since the ansition to an unregulated market is ibstantially complete, the proposed Special Rule No. 5 would not provide wholeaale purchaser-resellers with a simllar guarantee of a volume of middle distulates equal to thelr base period use, but would limit the ellglble rectpients to wholesale purchaser-consumers and endusers who are expertencing hardship or emergency conditions and to wholesale purchase-resellers which require middle distillates to meet the emorgency needs of such wholesale purchaser-consumers and end-users.

\section{REQUEST FOR SPECIFIC COMSOENTS}

Since the States play an integral role in the operation of the set-aside procedure, FEA is soliciting their comments as to how the operation of the set-aside might be improved. Comments are particularly sought with respect to the following specific modificatlons suggested by certain States at the hearings held this past summer.

First, many States experfenced problems in the enforcement of their orders. To alleviate this diffeulty, some states have proposed that prime suppliers be required to physically store set-aside volumes in each States and to segregate the set-aslde volume from other available supplies. Other States have suggested that the regulations specify the response time within which companies must fill orders. FEA belleves at this time that requiring seperate physical storage in each State for set-aside volumes could entall substantial expense and that it would be Impractical to require segregated shortterm storage of set-aside volumes. Furthermore, requirements such as these would not necessarily facilitate the distribution of the product. For example. If the product were released from set-aside obligations, suppliers might have logistical problems in transporting and dellvering supplies from diverse locations. As to a specifled response time for suppliers, FEA recognizes that the appropriate response times will differ depending upon innal ronditions and that a provision for a dellvery deadline in the regulatlons would be difficult to enforce. However, FEA wishes to make clear that suppliers are required to comply as soon as practicable with the terms of authorizing documents presented to them.

Second, transfers of middle distiilates from a prime supplier of one brand to a user of a different brand proved dificult in many States. FEA invites further comments on slich occurrenices so that the actual areas of concern might be more clearly delineated, and so that the Agency may determine what action. If any, FEA should propose to address this problem.

Many States expressed the opinton that the set-aside program would functlon more efficiently with provisions for federal enforcement of State set-aside orders and mandatory penalties for noncompliance. However, FEA's tentative conclusion at this time is that state en- lorcement is more appropriate due to the necessity for expedited relief in many Instances and the State Offices' famillarity with the documentation underlying and justiflcation for the relief in setaside orders.

Several States depend heavily on a particular type of middle distullate, and they suggested revising Form FEA 1000 . so that the volumes of each type of middle distillate being sold in the strate would be disclosed, which would enable the State to accurately calculate the allocable supply for each fuel type. FriA believes that this point has merit and is considering requiring the reporting by prime suppliers of separate volumes for each type of middle distillate.

Finally, most States consldered the four percent set-aside figure sufficlent under normal winter conditions, but several States thought the rule should allow a State's governor the rlght to petition FEA to Increase the percentage during extreme emergencles. If such an emergency does arise this winter, FEA intends to take whatever further action is necessary to ensure supplles to consliners, which action could include such a procedure for an increase in the set-aside percentage.

\section{Comment Phocedures}

Interested persons are invited to participate in this matter by submitting. data, views or arguments with respect to the proposals set forth in this notice to Executive Communications, Room 3317. Federal Energy Administration, Box PT, Washington, D.C. 2 G461.

Comments should be identified on the outside envelope and on documents submitted to FEA Executive Communications with the designation "Proposal for Relnstituting Distillate Set-Aside." Fifteen coples should be submitted. All comments recelved by October 21, 1977 , before 4:30 p.m., e.s.t., will be considered by FEA before final action is taken in this matter.

Any information or data considered by the person furnishing it to be conf.dential must be so Identified and submit.ter in writing. one copy only, FEA reserves the right to determine the confidential stivtus of the information or data and to treat it accorcing to its determinallon.

The public hearing in this proceeding will be held at 9:30 n.m., e.s.t. on October 21, 1977 and will be continued. If necessary, to October 25,1977 , in Rooin 2105, 2000 M Street, NW., Washington, D.C. 20461 . in order to recelve comments from interested persons on the matters set forth herein.

Any person who has an Interest in this matter, or who is a represertative of a group or class of persors that has air interest in this matter, may make a written request for an opportunity to make an oral presentation. Such a request should bo directed to Executive Commlirications, FEA, and must be received before 4:30 p.m., es.t., on October 14, 1977. Such a request may be hand delivered to Poom 3317, Federal Building, 12th and Pern- sylvanta Avenue, NW. Washirgton, D.C.: between the hours of $8: 00$ a.m. and $4: 30$ p.m., Monday through Friday. The person making the request should be prepared to describe the interest concerned, If epproprlate, to state why he or she is a proper representative of a group or class of persons trat has such an Interest, and to give a concise summary of the proposed oral presentation and a phone number where he or she may be contacted through October 21, 1977. Each person selected to be heard will be so notifted by FEA before 4:30 3.m., e.s.t.. October 18, 1977 and must submit 100 copies of his or her statement to Alocation and Pricing Regulations Development Offlce, FEA, Room 2214, 2000 M Street, NW., Washington, D.C. 20461, before 4:30 p.m., e.s.t., October 19, 1977.

FEA reserves the right to select the persons to be heard at the public hear: ing. to schedule their respective presen:tations, and to establish the procedures governing the conduct of the hearing. The length of each presentation may be IImited, based on the number of persons requesting to be heard.

An FEA officlal will be designated to preside at the hearing, which will not be a judiclal or euldentiary-type hearing. Questions may be asked only by those conducting the hearing, and there will be no cross-examination of persons presenting statements. At the conclusion of all initial oral statements, each person who has made an oral statement will be given the opportunity, if he or she so desires, to make a rebuttal statement. The rebuttal statements will be given in the order in which the initial statements were made and will be subfect to. time limitations.

Any interested person may submit questions, to be asked of any person making a statement at the hearing, to Executive Communications, FEA, before $4: 30$ p.m. e.s.t., October 19, 1977. Any person who wishes to ask a question at the hearing may submit the question, in writing, to the presiding officer: FEA or the presiding officer, If the question is submitted at the hearing. will determine whether the question is relevant and whether the time iimitations permit it to be presented for answer.

Any further procedural rules needed for the proper conduct of the hearing will be announced by the presiding officer.

A tranccript of the hearing will be made and the entire record of the hearing. including the transcript. will be retained by FEA and made avallable for inspection at the FEA Freedom of Information Offce, Room 2107. Federal Building, 12th and Pennsylvania Avenue, INW., Washirigton. D.C., between the hours of $3 \mathrm{am}$. and 4:30 p.m.. Monday through Friclay. Any person may purchase a copy of the transcript from the reporter.

As required by section $7(c)$ (2) of the Federal Energy Administration Act of 1974, Pub. L. 93-275, a copy of this notice has been submitted to the Ad- 
ministrator of the Environmental Protection Agency for his comments concerning the impact of this proposal on the quality o: the environment. The Adminlstrator had no comments.

In accordance with Executive Order 11821 and OMB Circular A-107, FEA is considering the inflationary impact of thls proposal

(Emergency Petroleum Allocation Act of 1973. Pub. L. 93-159. as amended. Pub. I 93-511, Pub. L. 94-99, Pub. L. 94-133, Pub. L. 94-163, and Pub. L. 94-285: Federal Energ7 Adminlstration Act of 1974. Pub. L. 93275, as amended. Pilb. L. Q4-332, and Pub. I. 84-385: Energy Pollcy and Conservation Act, Pub. L. 94-163, as amended. Pub. L. 94-385; E.O. 11790, 39. FR 23185; E.O. 11933, $41 \mathrm{FR}$ 36641.)

In consideration of the foregoing. Part 211 of Chapter II. Title 10 of the Code of Federal Regulations, is proposed to be amended as set for th below.

Issued In Washington, D.C., September 30,1977 .

\section{ERYC J. FYGr, Acting General Counsel.}

The Appendix to Subpart A of Part 211 is amended by adding Special Rule No. 5 to read as follows:

\section{SPxul, RTLE No. $B$}

\section{SPECZ1 SET-ASEE PROCEDUAES FOR MDDLE} DISTMLATES

1. Scope. This Speclal Rule provldes for a set-as!de program for middle distlllates for the months o: November 1977 through March 1978 , as provided below, notwithstanding the axempition of midalo distlliates from the Iisndatory Petroleum Allocation and Price i.egulations efiective July 1. 1978.

2. Proviston for middle distillate set-astde. notwithstanding the provislons of paragrepla (b) and (c) of $\$ 210.35$ and of parastaphs (b) (5) and (6) of $\$ 211.1$, a set-aside is herebs established for the months Novemjer 1977 through March 1979 for designated middie distllates for assignment by stale Offices in sccordance with the provistons of inis Spec!al Rule.

Fo: purposes of thls Special Rule the term middie dist'intes Includes the following, as defaned in 212.31 of this chapter: No. 1 reeting oll. No. 1-D diesel fuel, No. 2 heating oll, No. 2-D diesel fuel and kerosene.

3. Set-aside volume. A prime supplier shall inform ench spproprlate State Oface monthly of the estimated volume of middle distlllates to be sold toto a Stato lor consumption wlinin that state. The set-gslue volumb i:cliable in a state for a particular month ciall be the sum of the amousts calculated iy muitlplying four (4.,e) percent by cach intime supplter's estimated portion of its to il supply for that month whlch will be sold inco that Stato's distribution system for conimpilon within the Strte. The set-aslde for - partlcuiar month cannot be accumulated . - deferter: it shall bo made avallable trom stocks of p:lane suppllers ahether directly or inrough thetr wholesale purchaser-resellers. 1. State representctice. Each supplier shall eslgnate a representatlve for each State in ihlch the suppller is a prime suppller to act $\therefore$ and on behalf of the prime suppller with -spcct to set-asido petitlons and assignicnts from the set-aside to be supplicd by iist prtrae supplter. Each prime suppller for + Stato shnll designate its representatire for ??at stato and shall notley in wrtting the proprla:o State and FEA Reglonal Omces of uch designstion within 10 days after the effectlve date of this Speclal Rule. The State Omce shall to the maximum extent possible consult with a prime suppller's representative prlor to Issuing any authorlzing document affecting set-asldo volumes to be pro vided by the prime suppller.

6. Eligible reciptents of set-astde volumes. The set-aside provided for by this Speclal Rulo shall be utillzed by the State Offces in issulng authorlzations to appllcants for desIgnated middle distlllates to bo supplied by a prime suppller to meet hardshlp and emergency requirements of wholesale purchaserconsumers and end-users. To facliltate re llef of the hardship and emergency requirements of wholesale purchaser-consumers and end-users. the State Office may also direct that a wholesale purchaser-reseller be supplled from the set-aside to enable the wholesale purchaser-rcseller to supply the emergency and hardshlp needs of wholesale pur chaser-consumers and end-users with whom the wholesale-purchaser had a suppller/purchaser relationship on November 1, 1977.

6. Term of assignments. Assignments to ellgible end-users and wholesale purchaserconsumers under sectlon 5 of this Specla Rule by a State Office shall be made to meet the emergency or hardshlp conditiong belng experienced during that perlod. Assignments $w$ wholesale purchuser-resellers shall be only lor the perlod necessary to preclude hardshlp and provide emergency raquirements to that wholessle purchaser-reseller's wholesale purchaser-consumers and end-users. No as signments under this Speclal Rule shall relate to ang pertod subsequert w Atarch 31. 1978.

7. Application for asstgnment. Al applicatlons for asslgnment under this Speclal Rule shall be made to the appropriate State Offce. which Ofice has Jurisdlction over the State In whtch the applicant conducts its business operstlons, in accordance with the procedures set forth in $\$ \$ 205.211-218$ of Subpart $Q$ of Part 205 of this chapter wlth respect to the Stato set-aside. except as otherwise provlded in this Speclal Fule and except that all appllcations by wholesale purchaser-resellers must be in writing.

8. Transfer of functions to $E E A$ Reglona Office. Ang State may elect Irrevocably at any time to transfer administration of the midnle distillato set-aslde established by this special Rule trom Its State ODce to the FEA Keglona Oftce which has Jurlsdlction over sald State. and wlll inform the FEA Reglonst Office in writing of such electlon. In the event of such an electlon by a particular state, all applicatlons by applicants conducting business within that State shall be made to the appropriste FEA Reglonal Offlce. With respect to applications mado to an FEA Reglonal OMce under this section all references to a State Office In this Speclal Rule and Subpart $Q$ of Part 205 of thls chnpter shall be ceemed to refer to the approprlate FEA Reglonal Ofnce. 9. Approval of application. If a State Office approves an appllcatlou for asslenment, it shall assign a prime suppller an amount to furnish from the set-aside to lite uppllcant to meet the expressed emergency or hardshlp condltlon. To determlre an spproprtate prlmo suppiter, the State OAfice may coordlnate wlth the State representatives of prime suppllers.

10. Authorizing document. The State Office shall Issue to an applicant granted an as slgnment a document authorizlng such asbignment. A copy of the authorizing document (or a sinimary) shall also ve provicied by the state Omce to the des!nnated Siate representativo of the prlme supulter assigned to the aprilivant. An authorlaling docliment not presented to ctiner tho primo supplier or a destignuted local distributor of the prime suppller wthin ten (10) days of Issuance bhall explre after that ten-day perlod.
11. Supplter's Responsibllttes. When presented with an authorlzing document, suppllers shall provide the assigned amount $c$ middle distlilates to an eppllcant. The au thorlzing document shall entitle the appl cant to recelve product from any conventent local distributor of the prime suppller from whlch the set-aslde assignment has been made. Wholesale purchaser-resellers of prime suppllers shall as non-prime suppllers, honor such authorizlng documents upon presenta tlon and shall not delay dellvertes requlred by the authorizing documents while confirming such dellverles with the prime suppller. Any non-prime suppller which provldes mlddio distlliates pursuant to an a uthorlzing document shall in turn recelve from its prime supplter an equivalent volume of the product. The requtrements of paragraph (b) of 210.62 of this chapter continue to apply to suppliers to whom an authorizing docu ment is presented pursuant to this Special Rule to prohlbit any form of discriminatlon (Including prlce discrimination) whlch has the effect of clrcumventing. Irustrating or Impalring the ablectlves, purmses, and, in. tent of this Special Rulo.

12. Prime suppliers. All prime suppllers shall designate middio distlliates from their set-asldo volume each month, as directed by the State Offlces, not to exceed the total seteside volume for such middle distillates for that month for the State concerned.

13. Release of set-aside. At any time during the month, a State Offce may order the release of nart or all of a prime suppller's setaslde volume through the prime supplier's normal distribution system in the State.

14. Orders issued by State offices. AuthorIning documents and other orders issued pursuant to this Speclel fivle shall be in writing and effectlve Immediately upon presentation to the prime supplier's deslgnated State representatlve. Authorling documents shall represent a call on the prime suppller's setaside volumes for the month or issuance irrespectlve of the fact that dellvery cannot be made untll the following month. Ang order issued by a state Office pursuant to this Spectal Rule may be sppesied to the FEA Reglonal Office that has furisdlction over the State Involved, in accordance with the procedures set forth in Suhpart; $H$ of Part 205 of this chapter. Any appeal from such an order shall be fled within ten (10) days of service of the order from which the appeal is taken. If a State Office falls to take action on an application within ten (10) days of filng. the applicant may treat the application as having been dented in all respects and may ap. pesl therefrom as provided in this section.

[FR Doc. 77-29287 Filed 10-3-77:8:45 am] 


\subsubsection{Order Refinery Yield Adjustments}

\subsubsection{Objective}

The objective of this measure is to maximize production of petroleum products that are in critically short supply either in local areas or nationwide.

\subsubsection{Concept of Operations}

Regulatory provisions for the issuance of refinery yield orders are currently part of the Mandatory Petroleum Allocation Regulations. Orders can be quickly issued upon a proper finding of fact. Depending on the degree of the mandated refinery yield, refinery compliance could range from short-term to as long as several weeks.

If significant spot shortages occur in the supply availability of certain products, refinery yield orders can be issued requiring specific refineries to process crude oil in a manner that will increase yields of fuel oil. Technical refinery design considerations limit how much the yield can be shifted.

\subsubsection{Benefits and Cost}

The benefit of increasing the output of certain products is obtained at the cost of a decrease in the supply of other products. The obvious benefit is to make more fuel oils available to meet industrial and residential demand during periods of severe winter weather. Orders which would disrupt refinery production should be avoided.

\subsubsection{Startup Plan}

Actions Taken

Agency

Completion Date

None

Actions Remaining

Monitor supply situation

DOE

Issue orders

DOE

Ongoing through the Winter

To be determined by DOE

\subsubsection{Special Requirements \\ None}

3.5.2.6 Documentation

Program (10 CFR 211.71).

Exhibit 3.5.2 Mandatory Refinery Yield Control 


\subsubsection{Grant Entitlements for Imported Middle Distillates}

\subsubsection{Objective}

The objective of this measure is to increase

the availability of fuel oil in the Northeastern regionof the United States.

\subsubsection{Concept of Uperations}

During last year's severe winter weather, the sharp increase in demand for middle distillates along with incapacity of the petroleum distribution system to move petroleum products to areas of peak demand necessitated an increase in middle distillate imports for the East loast (PAD I). These imports were significantly more expensive than middle distillates produced in the United States from price-controlled crude. In order to encourage the importation of middle distillates to meet the temporary surge in demand and to ease the impact on residents of the East Coast, entitlement relief was granted to middle distillate imports. A value of $\$ 2.10$ per barrel was assigned so that the full benefit could be immediately passed through to consumers.

If this measure is implemented this winter, the procedure will be essentially the same as that followed last winter. Once a finding has been made that middle distillate entitlements are heeded to insure adequate supplies in the Northeast, a notice could be published in the Federal Register.

\subsubsection{Benefit and Cost}

Principally, the measure reduces the impact of higher-priced imports of middle distillates on residents of the Northeast. Therefore, residents of the Northeast pay proportionately less for petroleum products while residents of other parts of the country pay proportionately more for all domestic refined products than they would without this measure. For February/March 1977, a total of 24.9 MMB of \#2 heating 011 were imported representing an entitlement value of $\$ 52.3$ million. The measure brings about a temporary increase in total middle distillate supplies in this country.

\subsubsection{Startup Plan}

Actions Taken

None

Actions Remaining

Issue Federal Register Notice
Agency

Completion Date 
3.5.3.5 Special Requirements

None

3.5.3.6 Documentation

None 
EXHIBIT 3.5.2

MANDATORY REFINERY YIELD

CONTROL PROGRAM

10 CFR 211.71

\section{[y 13,651$]$}

$\$ 211.71$ Mandatory refinery yield control program.

[T 13,651.05]

(a) Purpose. The refinery yield control program is designed to require each refiner to utilize available supplies of crude oil in a manner best suited to ensure adequate production levels of refined petroleum products and residual fuel oil which are or may be in short supply. consistent with the objectives of this chapter.

\section{[I] 13,651.10]}

(b) Scope.: This section applies as specified to the production of sefined petroleuni products and residual fuel oil from crude. oil by each refined in the United States.

$[\pi \cdot 13 ; 651.15]$

(c) Product yield controls.

(1) Definitions. As used in this:section-

"Adjustment factor" means the percentage established by the FEO by: which the base percentage yield of 2 particular refined petroleum product:or residual fuel oil is multiplied to obtain the adjusted percentage yield of that particular product or residual fuel oil.

"Adjusted percentage yield" means the product of the base percentage yield of a particular refined petroleum product or residual fuel oil multiplied by the adjustment factor for that product or residual fuel oil.

"Base percentage yield" means the ratio expressed as a percentage, which the total number of barrels of a particular refined petroleum product or residual fuel oil produced by a refiner during a specified base period bears to the refiner's total crude runs to stills in that base period.

(2) Adjustment-of .base percentage yield. Whenever a refined petroleum product or res:dual fuel oil is or will be in short supply, the FEO may require refiners to adjust their base percentage yield of 
that product or residual fuel oil in order to increase the relative output of that product or residual fuel oil in short supply. If the FEO determines that an adjustment to the base percentage yield of a particular refined petroleum product or residual fuel oil is necessary, the FEO shall publish an adjustment factor by which each refiner must multiply its base percentage yield of that product or residual fuel oil to obtain the adjusted percentage yield of that product or residual fuel oil.

(3) Joint compliance. Upon approval by the FEO, two or more refiners may adjust their base percentage yield of a particular refined petroleum product or residual fuel oil on a pooled basis, such that the combined production of that product or residual fuel oil by the two or more refiners would equal the combined production of those refiners if each refiner had separately equalled or exceeded its adjusted percentage yield of that product-or residual fuel oil.

\section{[I] 13,651.20]}

(d) Allocation of crude oil. The FEO may adjust the quantities of crude oil allocated among refiners under section 211.65 in a manner designed ta ensure desired production levels of refined petroleum products or residual fuel oil in short supply for whici an adjustment factor has been established. Such adjustments shall be designed to meet the objectives of this chapter and of the Act;-sucb that refiners which increase production in excess of their adjusted percentage yield of that product or residual fuel oil, or less than the adjusted percentage yield of that product or residual fuel oil may be allocated greater or lesser quantities of crude oil during the next allocation quarter, respectively.

\section{[II $13,651.25$ ]}

(e) Adjustments in production:levels of kerosene-base jet fuel and No.: 1 fuel oil. (1): Whenever FEA determines that No. 1 fuel oil is or potentially will be in short supply in any. region or area of the United States, FEA may require one or more specified refiners, which produce kerosene-base jet fuel and supply or are capable of supplying Na. 1 fuel oil in or into those regions or areas experiencing shortage 
conditions; to adjust their yrelds of kerosene-base jet fuel to levels that permit them to supply that product at an allocation fraction specified in such order or orders and to increase production and supplies of No. 1 fuel oil.

(2) Any such order may by its terms apply only to one or more refineries specified in the order and owned by the refiner to which the order is issued and shall be effective for the period specified in the order.

(3) The terms of any order issued under the authority of this paragraph shall be subject to review and comment by the refiner arid the other principal parties affected thereby prior to the issuance thereof, if the FEA determines that the shortage situation in response to which the order is to be issued permits these review and comment procedures to take place withmi arversely affecting supplica of No. 1 fuel vil in the particular region or area. Any, such order shall be appealable pursuant to subpart $\mathrm{H}$ of Part 205 of this chapter. 


\subsubsection{Impose Allocation Controls}

\subsubsection{Objective}

The objective of this measure is to prevent

drastic increases in petroleum prices and promote equitable distribution of scarce supplies.

\subsubsection{Concept of Operations}

During the 1973-74 oil embargo, Congress passed the Emergency Petroleum Allocation Act authorizing the imposition of price and allocation controls on crude oil and petroleum products. These controls, imposed at the wholesale and distribution level, remained in place following the end of the embargo. The Energy Policy and Conservation Act of 1975 (EPCA), which was enacted in December 1975, authorized the President to decontrol specific petroleum products (unless disapproved by Congress) and place the associated price and allocation regulations in standby status. At this time middle distillate and residual fuel oil are the major petroleum products which have been decontrolled.

The price and allocation regulations which are presently in standby status could be reimposed by the President selectively in the event of a severe supply disruption of one or more petroleum products. Implementation of the existing regulations in their present form may not have the desired results since key regulatory provisions have been modified to deal with adequate supply rather than a shortage.

In some cases, the existing regulations were modified to reflect the fact that product has become plentiful and are therefore no longer appropriate to deal with a shortage situation. Thus, some changes are needed to return the regulations to a status where they are capable of allocating a short supply. Prior to implementation of mandatory allocation, industry would be encouraged to establish voluntary allocations to handle spot shortage situations.

\subsubsection{Benefit and Cost}

Reimposition of controls would prevent drastic increases in prices and promote equitable distribution of scarce supplies. The program does involve extensive administrative manpower at the Federal level and extra paperwork for business, but it is estimated that present DOE staffing would bc available on transfer from other functional areas.

\subsubsection{Startup P1an}

Actions Taken

Agency

Completion Date

None 
Actions Remaining

Propose required amendments to standby regulations

Hold public hearings

Finalize regulations

Implement regulations
Agency

DOE

DOE

DOE

DOE
Completion Date

November 30

December 15

January 15

As needed

\subsubsection{Special Requirements}

Revision to standby regulations and finding by President that implementation is necessary.

\subsubsection{Documentation}

None 


\subsubsection{Drawdown Strategic Reserves}

3.5.5.1 Objective

The objective of this measure is to make strategic reserve oil available to supplement scarce petroleum supplies.

\subsubsection{Concept of Operations}

Title I of the Energy Policy and Conservation Act of 1975 requires the establishment of a strategic petroleum reserve. The first fill of the strategic reserve program began in July, 1977 . It is expected that 15 million barrels will be in storage by December, 1977 . increasing to 37 million barrels by March, 1978. An additional 6 million barrels of imported crude will be enroute to the reserve sites.

Strategic reserve oil can be used only with a Presidential finding of a severe supply disruption or to fulfill international sharing agreements. Drawdown must be in accordance with the Distribution Plan included in the SPR plan.

Since the most readily accessible SPR oil would be the supplies enroute to storage sites, the first action should be to redirect the tankers to ports servicing areas of critical need. This oil and oil in the storage facilities would enter directly into the distribution system for delivery according to established allocation priorities.

\subsubsection{Benefit and Cost}

It is anticipated that oil actually in the reserves could be delivered at a rate of $115 \mathrm{MBD}$ during the winter period. The 6 million barrels enroute would be available whenever the tankers arrive. Although this amount does not constitute a significant portiun of total imports, it could be used to meet critical needs during the winter heating season.

If SPR oil is used, the cost will be equalized with that from other available supplies according to provisions of the petroleum pricing regulations in effect at that time. The oil has been purchased from producing countries at contracted prices. 0ther costs would include those involved in pumping the oil from the storage sites.

\subsubsection{Startup Plan}

Actions Taken

$0 i l$ placed in strategic reserves $\mathrm{DOE}$
Agency
Completion Date

Ongoing from July, 1977. 
Actions Remaining

Report to Congress concept of distribution plan

Hold hearings

Issue final regulations

Implement drawdown
Agency

DOE

DOE

DOE

DOE
Completion Date

December 15

December 31

February 15

As needed

\subsubsection{Special Requirements}

Presidential finding that implementation is requilred due to a severe energy supply interruption.

\subsubsection{Documentation}

None 


\subsection{Transportation}

During last winter's severely cold weather, spot shortages of energy supplies were caused or aggravated by weather-induced disruptions in normal fuel transportation and distribution systems. Many waterways were frozen, including such major channels as the Ohio and Mississippi Rivers, preventing barge deliveries to many localities. Heavy snow and ice prevented deliveries by truck and rail. In at least one major city, Buffalo, the weather conditions were so bad that all forms of transportation came to a standstill. for several days.

Last winter, federal, state and local ofticials took a variety of actions to restore normal transportation as quickly as possible. Many states cailied out the National Guard. State restrictions on truck weight and size limitations were lifted temporarily. For the most part, such local actions are the most effective measures that can be taken.

The Task Force has identified, however, several actions which the Federal Government can take to expedite emergency transportation and distribution of fuel supplies. Several of these measures were implemented last winter and involve temporary relaxation of ICC and DOT regulations. others are more drastic and would be used only as measures of last resort.

\subsubsection{Suspend Driver Hours of Service Restrictions}

\subsubsection{Objective}

The objective of this measure is to expedite the delivery of fuel and other essential commodities in an emergency.

\subsubsection{Concept of Operations}

DOT has regulations regarding the total number of hours during a 24-hour period during which a truck driver may operate his/her vehicle. In an emergency DOT can temporariily suspend these regulations by publishing a Notice in the Federal Register and notifying field office personnel to halt enforcement activities.

\subsubsection{Benefits and Cost}

In the event of spot shortages of energy supplies and other essential commodities, this measure an be used to expedite deliveries to localities in critical need. It could also permit trucks to supplement other forms of transportation if cold weather should close waterways, etc. The measure could involve a slight safety risk due to longer than normat hours of operation. 
3.6.1.4 Startup Plan

Actions Taken

Agency

Completion Date

None

Actions Remaining

Issue Federal Register

DOT

To be determined

notice and notify DOT

by DOT

field offices

3.6.1.5 Special Requirements

None

3.6.1.6 Documentation

None 


\subsubsection{Defer Vehicle Inspection Requirements}

\subsubsection{Objective}

The objective of this measure is to make additional trucks available to transport fuel and other essential commodities in an emergency.

\subsubsection{Concept of Operations}

DOT has regulations requiring periodic inspection of trucks used to transport fuels and other commodities. In an emergency DOT can temporarily defer these requirements by publishing a Notice in the Federal Register and notifying field office personnel to halt enforcement activities.

\subsubsection{Benefits and Cost}

In the event of spot shortages of energy supplies and other essential commodities, this measure can be used to make additional vehicles available for delivery to localities in critical need. It could also permit trucks to supplement other forms of transportation if cold weather should close waterways, etc. The measure could involve a slight safety risk due to undetected violation of equipment safety requirements.

\subsubsection{Startup Plan}

Actions Taken

Agency

Completion Date

None

Actions Remaining

Issue Federal Register

DOT

To be determined

notice and notify DOT

by DOT

field offices

3.6.2.5 Special Requirements

None

3.6.2.6 Documentation

None 


\subsubsection{Waive Jones Act}

\subsubsection{Objective}

The objective of this measure is to permit limited use of foreign flag vessels to supplement American vessels for fuel deliveries in the interest of national defense.

\subsubsection{Concept of Operations}

The Jones Act (46 U.S.C. P883) precludes the use foreign flag vessels for deliveries between U.S. ports. However, the Act of December 27, 1950 (64 Stat. 1120) does contain a provision authorizing the Secretary of the Treasury to waive this restriction when necessary in the interest of national defense. Under this provision, any private or public organization may request authorization to use a foreign flag vessel for transport between American ports. Any request from the Secretary of Defense must be approved; other requests may be approved if the Secretary of the Treasury determines such a waiver is necessary in the interest of national defense.

\subsubsection{Benefit and Cost}

In an emergency this measure could enable the transport of fuel to localities in critical need. However, the maritime industry and unions and their Congressional supporters vigorously oppose any waiver of the Jones Act.

\subsubsection{Startup Plan}

Actions Taken

Agency

Completion Date

None

Actions Remaining

Make a recommendation of necessity for waiver in the interest of Any Federal As required national defense. agency

3.6.3.5 Special Requirements National defense finding

3.6.3.6 Documentation

The Act of December 27, 1950 (61 Stat. 1120) 
[CIAPTER 1155]

Derml.cr 27, 10:0

[11. K. $24: 411$

[Futic Lor b91]

Navigalinn nud rese ri-inepretion laws. viniver. Trrminition of alt-
thrity.

neneni.

To authorize the waver of the uavigalion nut vassel-inspretion laws.

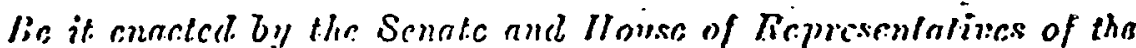

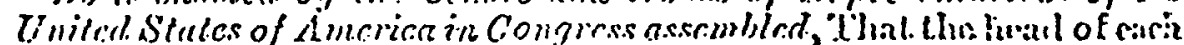
dip:urtuent or ageney respionsible for the athministration of the narigalion and vessel-inspection la ws is diverfel to waive conpliance wit. suleh laws upon tho reyurst of the Secretay of Defense lo the cxient deenerl necessing in the interest of nal ional defense by the secerelary of Defense. The hearl of snch department or azemey is antherionit to waive compliance with such hus to sich extenta and in such mannor

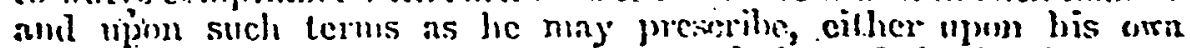
intiative or upion tho writen ecemmundalion of the luead of any other Government agency, whenerer lyedrems that such action is - necessiury in the infersat of national rofonse.

Sic: 2. The authoeity granterl by this Art. shall trominafe af surli time ns tho Congress by concurent resolution or the P'resident minj desiprinate.

Srre. 3. 'The joint resolution cntithd "Joint resolution nut Thoriang thu Commandint of the United States Const. Fundel to vaive crintplinure with the maviration and vessel-inspection liw:s atminislered

AnU.s.o..sun. UIr. nnee pirse. $5 i$. hy' the Coast Guirel", approved Mlarch 31, 10:1'T (61. Silit.-33) is ninemiled, is repentent.

Approved December 27, 1950. 


\subsubsection{Grant Emergency Temporary Authority to Transport Critical Commodities}

\subsubsection{Objective}

The objective of this measure is to expedite truck deliveries of essential commodities.

\subsubsection{Concept of Operations}

ICC regulations require transport carriers to apply for authority to carry specified commodities between specific points. Regulated carriers which have not received such authority are not permitted to operate over these routes.

Last winter the ICC issued Gerierd Temporary Order \#10 authorizing its field offices to grant emergency temporary authority by phone to carriers to transport fuel and other essential. commodities. Hundreds of requests were approved; none were denied. In the event of another severe winter, ICC can update and reissue General Temporary Order \#10, authorizing ICC field office personnel to approve requests for emergency temporary authority by phone.

\subsubsection{Benefit and Cost}

This measure could expedite delivery of fuel and other commodities. The extra administrative work involved could require additional personnel in ICC field offices.

\subsubsection{Startup Plan}

Actions Taken

Agency

Completion Date

None

Actions Remaining

Update General Temporary

ICC To be determined by ICC Order No. 10, publish in Federal Register, notify ICC field offices

3.6.4.5 Special Requirements

None

3.6.4.6 Documentation

January 21, 1977.

General Temporary Order No. 10, dated 
ORDER

EX PARTE NO. NC-G!
SรRYCE SATE

133

At a Session of the INTERSTATE COMMERCE COMinISSION, Division 1, held at its ofia ce in Washington, D. C., on January 21, 1977

GBNERAL TEMPORARY ORDER NO. 10

SECTION 210aía)

The Interstate Commerce Commission having under consideration the urgent need for motor carrier services due to severe winter weather conditions, the national itansportation policy, the public interest, and, among otiers, Sections 202(a). $20 \wedge(a)(6)$, and $210 a(a)$ of the Interstate Comnerce Ac: ard

It appearigg, That due to feezing temperatures, certain carciers are unable to transport passengers and property tendered to ties; and that an emergancy exists in ail sections of the United States requiring immoilate action on the part of the Commission to make provision for adequate ransportation of essemial commodities, irciuding but not linited to scae listed below, in the interest of tive public and the mational deferse:

Food or kindred products, camed, preserved of vtherwise prepared, including fresh, frozen or chilled meats adi pouitry; fresi eggs and milk; fresh or frozen fruits and vegetables; fresi or frozen fish and shell fish; feeds for arimals and fowls.

Fiospital and sick room supplies and equipment, ixcluding diagnositic devices and essential support utilizies.

Pharmaceuticals, biologicals, surgical textiles acd instrumenis,

Medical iacoratory supplies and equipment,

Professional dental sipplies and equiprent.

Fuels required for the praduction of electic power and hiose used directly for heating residences ard institutions essential for the pullic welfare.

- Electicej poner and communication systems zopair materials and equipment required for the continusd sups:y of essential electric porkex and communicerions. 
Essential supplies and materials directiy related to exploration, development and construction of energy-producing systems.

Neterial moving on Government or commercial bills of lading specifically certified as essential by Department of Defense, Energy. Research and Development Administration or General. Services Administration contract administrators.

All material moving on Government bills of lading issued by transportation officers of the military services.

U. S. meil in accordance with emergency orders issued by the Postunaster General.

Water and sewage processing and handling supplies and equipment, including chlorine, alum, lime, sulphate of iron; soda ash, and similar chemicals and equipment essential to the continuity of operation of water and sewage installacions.

Items necessary to the continted smooth furctioning of the finanictal. system, i. e., moyement of chesks; curiency and coins.

Federal Government personnel on agency-designated essintial travel oxders and non-Federal Governinent personnel on self-designated. essential travel in support of items contained in this priority list.

It further appearing; That there exists an immediate and urgent need for additional motor carsier service to supplement temporarily the transportation facilities of the Nation for the movement of military and other freight, and passengers;

And it further appearing, That the present transportation emergency and immediate need.for maximum utilization of motor carrier facilities, equipment, and service. have mide it necessary for the Commission to provide and author:ze a more flexible. metis $\propto$ whereby motor carriers, and other persons, may obtain remporary authorizatons to render the required motor service necessary in the public interest and to the rational defense,

Ii is ordered, That pursuant to Section $210 a(a)$ of the Interstate Commerce Act: ( $\Leftrightarrow 9$ U.S.C. $310 a(a)$ ), all persons who shall apply to any regional operations clisector, assistazt regional operations director, district supervisor, or their designees, of ine Connission's Bureau of Operations are kereby granted temporary authority to Itansport passengers or property by motor venicle for a pericd of not morenthan $30 \mathrm{du}$ s to the exient and scope that sucin regional operations director, assistant regrozal operations director, district supervisor, or their designees, shall. certify 
that due to the existing transportation emergency, there is an immediate and urgent need for the service applied for, and there is no available carrier service capable of mestiting orich neesis

It is further ordered, That the grant of such temporary authority be, and it is hereby, conditioned upon satisfying the said regional operations director, assistant regional operations director, district supervisor, or their designees, of full cumpliance by the grantee with all applicable statutory and Commission. requirements concerning tariff publications, evidence of security for the protection of the pliblic, and designation of agents for service of process, and further conditioned upon such tariff publications quoting rates, fares, ard charges no lowrer than those of existing rail, water, or motor carriers in the territory in which the operations are to be authorized;

It is further ordered, That service performed under temporary authority gränted pursuant to this order shall in no way constitute eviderice or a showing warranting futture issuance of a certificate of public convenience and necessity or permit, as provided in Section 207fa) of the-Act ( $\leqslant 9$.U.S.C. 307(a)) and Section $209($ b) of the Act (49 U.S.C. 309(b)).

It is further ordered, That temporary authority granted pursuant to this ordex shall expire as of the first midight after the issuance of an order by this commission revoking General Temporary Order No. 10 except as to passengers and property, the trarsportation of which. was begun prior to that time;

It is further ordered, That this order shall become effective oif the 22nd of January,'19.77, at 12:01 a.m.

Ano it is further ordered. That notice of this orcier. shall be given to motor car. riers, other parties of interest, and to the general public by depositing a copy thereof in the Office of the Secretary of the Cominission, Washington, D. C., and by filing a copy thereof with the Director, Office of the Federal Register.

By the Commission, Division 1, Commissioners Musphy, Gresham and MacFarI

ROSERT L. OSWALD

SECRETARY

(SEAL) 


\subsubsection{Direct Priority in Movement}

\subsubsection{Objective}

The objective of this measure is to expedite delivery of fuel and other essential commodities.

\subsubsection{Concept of Operations}

ICC regulations authorize the agency to direct regulated railroads to carry specified commodities between specified points in an emergency. This action has been taken in the past during a number of weather-related emergencies. In the event of another severe winter ICC can issue a car service order similar to service order No. 1257 issued January 21, 1977.

\subsubsection{Benefit and Cost}

This measure can expedite delivery of fuel and other essential commodities. It could delay delivery of shipments having lower priority.

\subsubsection{Startup Plan}

Actions Taken

None

Actions Remaining

Update Service Order

No. 1257, publish Notice

in Federal Register, notify

Ascociation of American

Railroads and American

Shortline Railroad Association
Agency

Completion Date

\subsubsection{Special Requirements \\ None \\ 3.6.5.6 Documentation \\ None}

To be determined

by ICC 


\subsubsection{Prohibit Trains from Entering Impassable Areas}

\subsubsection{Objective}

The objective of this measure is to prevent a major tie-up of stranded railcars.

\subsubsection{Concept of Operations}

ICC regulations authorize the agency to restrict regulated railcars from entering localities where severe weather conditions have rendered movement hazardous. This action was taken last winter when heavy snowfall hit the Buffalo area. In the event of a severe emergency, this action could be taken again by issuing an order through the Association of American Railroads.

\subsubsection{Benefit and Cost}

This measure can be used to prevent a major tie-up of stranded railcars. On the other hand, during the duration of an embargo the locality could be in short supply of fuel and other critical commodities. The measure could also disrupt rail schedules.

\subsubsection{Startup Plan}

Actions Taken

Agency

Completion Date

None

Actions Remaining

Issue embargo order and

ICC

To be determined by ICC

notify Association of

American Railroads

Carefully monitor conditions

so that embargo can be terminated promptiy

ICC

\subsubsection{Special Requirements}

None

3.6.6.6 Documentation

None 


\subsubsection{Direct Movement of Privately Owned Railcars}

\subsubsection{Objective}

The objective of this measure is to grant ICC maximum flexibility in directing movement of fuel and other essential commodities to areas in greatest need.

\subsubsection{Concept of Operations}

ICC authority to direct railcar deliveries does not extend to privately owned railcars. Many of these railcars are designed for transport of propane and petroleum. In the event that severe weather conditions cause spot fuel shortages, such cars could be diverted to other areas of the country to service localities in critical need. Implementation of this measure would require specific Congressional authority. If conditions are so severe during the coming winter that this measure is warranted, ICC will draft legislation to be submitted for Congressional approval on an emergency basis.

\subsubsection{Benefit and Costs}

This measure would grant ICC maximum flexibility in directing movement of fuel and other essential commodities to areas where they are needed. Many fuel railcars, in particular, are privately owned. The measure could disrupt normal operations among those firms whose. railcars are diverted for use.

\subsubsection{Startup Plan}

Action Taken

None

Action Remaining

Draft legislation

Submit legislation

to Congress

Enact legislation
Agency

Completion Date

3.6.7.5 Special Requirements

New legislation

3.6.7.6 Documentation

None

ICC To be determined

by ICC

ICC

Congress

3.6.7.6 Docunentation 


\subsubsection{Implement Priority and Allocation Authority}

\subsubsection{Objective}

The objective of this measure is to amend Executive Order 10480 to permit FPA to authorize DOT to exercise priority and allocation authority in a defense-related emergency.

\subsubsection{Concept of Operations}

The Defense Production Act authorizes the establishment of priorities for movement of essential goods in the interest of the national defense. Under Executive Order 10480, which implements the Act, DOT obtains specific authority from FPA. OMB processes the implementing order to the President for signature.

Under this measure FPA will be authorized to permit DOT to exercise priority and allocation authority over transportation in a defense-related emergency.

\subsubsection{Benefits and Cost}

This measure would permit DOT maximum flexibility to ensure that essential commodities can be transported to areas of critical need in an emergency. However, scheduled carrier operations could be dis rupted.

\subsubsection{Start-up Plan}

\begin{tabular}{|c|c|c|}
\hline Actions Taken & Agency & Completion Date \\
\hline $\begin{array}{l}\text { Submitted recommended } \\
\text { revisions to Executive } \\
\text { Order } 10480\end{array}$ & DOT & June, 1977 \\
\hline $\begin{array}{l}\text { Circulated revised } \\
\text { Executive Order } 10480 \\
\text { for comment }\end{array}$ & FPA & August, 1977 \\
\hline \multicolumn{3}{|l|}{ Actions Remaining } \\
\hline Finalize revised order & FPA & October, 1977 \\
\hline Issue revised order 10480 & President & Mid-November, 1977 \\
\hline
\end{tabular}

\subsubsection{Special Requirements}

Revised Executive Order 10480

\subsubsection{Documentation}

None 


\subsection{Demand Restraint Measures}

Demand restraint measures are intended to effect an immediate and significant reduction in demand for energy. In contrast to ongoing conservation programs which focus on unnecessary energy consumption, demand restraint measures are designed to reduce or el iminate consumption which, in non-shortage conditions, would be considered desirable and even essentiat.

The objective of demand restraint in an emergency is threefold: (1) to reduce the supply-demand imbalance, (2) to direct the available supply to the most important uses, and (3) to minimize the confusion that results from uncontrolled competition for scarce energy supplies.

During recent energy shortages the states have taken the lead in implementing demand restraint programs. This approach has a number of advantages since states can tailor their demand restraint activities to their specific needs, provide local enforcement, and assess ef:fectiveness on a continuing basis.

In the event of any energy emergencies this winter, this plan envisions that the states will again take the initiative in implementing demand restraint programs. It is likely that Federal intervention would be contemplated only in the event of a very severe (Phase IV) shortage or if serious equity problems developed among the states.

In the course of assessing the appropriate Federal role in achieving demand restraint, DOE has reviewed the effectiveness of measures which were implemented by the states and localities during recent energy emergencies, primarily the 1973-74 oil embargo and last winter's natural gas shortage. This review indicates that the states have had varying degrees of experience and success in effecting demand restràint.

In order to promote an interchange of information among the states and localities with respect to the effectiveness and problems associated with various winter-related demand restraint measures, and to identify areas in which the Federal Government can assist the states in this regard, DOE will conduct workshops in five regional offices in mid-November. All states will be invited to participate. A variety of measures will be discussed including:

1. Reduction of thermostat setting for space conditioning

2. Reduction of thermostat setting for water heating

3. Reduction of decorative and other non-essential lighting in the commercial sector.

4. Reduction in hours of operation

- commercial stores and office buildings

- schools 
5. Industrial fuel substitution

- Relaxation of air pollution control requirements to permit use of more pollutant fuels

- Curtailment in the requirement to use air pollution control equipment

The findings and conclusions of the workshop participants will be provided in a report to all states in early December. 


\subsection{Materials Allocation Measures}

\subsubsection{Allocate}

\subsubsection{Objective}

The Energy Policy and Conservation Act (EPCA) amends the Defense Production Act of 1950 to provide for the use of a priority and allocation system for obtaining supplies and materials for the energy. program and projects which will maximize domestic energy supplies. Prior to invoking this authority the Department of Energy (DOE) must designate the supplies as critical and essential and the Department of Commerce (DOC) must rule that the supplies are scarce and determine there is a need to use the system. The measure ensures that:

1. Supplies of materials and equipment are available on t.ime.

2. Supply requirements are equitably distributed among suppliers.

3. Supply requirements are not in excess of actual needs.

4. The program is implemented in a way that will minimize hardship in the marketplace.

\section{Concept of Operations}

A system for prioritizing and allocating essential materials and equipment for national defonse alreddy exists under the Dcfense Pruduction Act (DPA). The Energy Policy and Conservation Act of 1975 (EPCA) broadens the concept to include domestic energy supplies for energy programs and projects. To implement this measure, an application must be submitted requesting a delermination that the program or project contributes to the improvement of the nation's energy resource situation. DOC and DOE must then demonstrate certain findings of scarcity and criticalness. After the findings are made, DOC will grant a priority authority to obtain the controlled supplies.

\section{Bcnefits and Costs}

This measure grants energy programs and projects that maximize domestic energy supplies a preferred npnnrtunity to obtaill scarce and essential supplies. The system also provides a mechanism for resolution of conflicting priorities. llowever, the measure does require a higher degree of coordination with other agencies. The measure also could be expanded to include provisions for the movement of essential goods. Actions are presently being taken by DOE and DOT to authorize this. 
Start-Up Plan

- Actions Taken

- Prepare procedural draft of guidelines for applicants

- Finalize application format

- Actions Remaining

- Review proposal to include transportation requirements in measure

- Obtain concurrence of DOE OGC

- Circulate final

version of guidelines for approval
Agency

ERD/FEA

ERD/FEA

Agency

FEA/DOC/FPA

DOE/DOC/FPA

Special Requirements

None

Documentation
Completion Date

July, 1977

September 30, 1977

Completion Date

November 30,1977

December 15, 1977

December 30, 1977

- Priorities Support for Energy Keeping Energy Programs on Schedule FEA/DOC

- Defense Materials System and Defense Priorities System 


\subsection{Assistance Programs}

This section of the Planning Guide contains supply and financial assistance measures which are available to state and local units of government to help mitigate the impacts caused by supply interruptions or the increased costs of utility and fuel bills.

The measure dealing with termination of utility services is solely within the purview of state and local governments. Except for the Handbook which will be developed by DOE, the other measures involve programs implemented by other Federal agencies and state and local governments.

The purpose of this section is to identify the programs currently available; these will be included in a Handbook as a reference for state and local governments.

While these measures were examined initially from the perspective of energy emergency planning, it soon became evident that the need for financial impact assistance is not solely dejendent upon fuel shortages. tnergy-related emergencies are encountered by many people who cannot pay energy bills under normal conditions of cold weather, simply due to higher relative costs of fuel, unemployment and other prohibitive factors. Energy shortages, severe weather conditions, or natural disaster only exacerbate the problem of low and fixed income persons who must pay high prices for fuel.

The information in this section, and that to be included in the Handbook is intended to encourage those states, which have not already done so, to assess their anticipated impact aseistance needs drid to review exlsting programs to see whether plans can be altered to free up resources to meet emergency energy needs this winter.

The measure on voluntary programs, which will be further detailed in the Handbook, hiyhlights the fine work that state, local governments and private organizations have done to take care of the needs of the citizens of their state. It is hoped that other areas will benefit from the identification of these projects and will initiate similar actions in their communities. 


\subsubsection{Distribute Energy Emergency Handbook}

\subsubsection{Objective}

To expedite coordination at all levels of government in an energy emergency and to provide information to state and local governments and industry officials to help them resolve energy emergencies.

\subsubsection{Concept of Operations}

During the winter of $1976-77$, there was a great deal of confusion at the state and local level because there was no reference guide to identify who could help, what they could do, and where and how to get aid.

In order to avoid a similar problem this winter, a Handbook is being prepared as a source of basic information.

The Handbook will identify types of problems likely to be encountered, programs available to mitigate the emergency, and key individuals or program offices at the federal, state, or local level which should be contacted about a given program.

The Department of Commerce previously produced a Handbook on Natural Gas designed to assist industry officials in dealing with natural gas shortages. OOC has updated the material, and since the material covered in the DOC Handbook is relevant to the WEEP Task Force effort, DOE entered into an interagency agreement with $D O C$ to make this a joint project. Accordingly, the DOC Handbook will be integrated with the WEEP Handbook.

The Handbook will be punched for insertion in a 3-ringed binder. A process will be developed to update the Handbook and diseminate changes to a regular distribution list.

\subsubsection{Benefit and Cost}

This Guidebook should help resolve much of the confusion caused last winter when no handbook was available on a widedistribution basis. Estimated cost of printing: $\$ 10,000.00$.

\subsubsection{Startup PIan}

Actions Taken

Outline of Handbook prepared
Agency

DOE
Completion Date

October 12 
Actions Remaining

Develop camera-ready copy of Handbook

Disseminate Handbook to state and local governments $\underline{\text { Agency }}$

DOE

DOE

\subsubsection{Special Requirements}

Reference lists of federal, state, local, and industry associates involved in energy-related areas.
Completion Date

November 25

December 10 


\title{
3.9.2 State and Local Voluntary Assistance Programs
}

\author{
3.9.2.1 Objective \\ Stimulate voluntary self-help assistance at \\ state and local. levels.
}

\subsubsection{Concept of Operations}

The Handbook will include descriptions of actions taken by state and local governments and private non-profit organizations last winter to assist those in need of fuel supplies or funds to cope with unusually high costs. For example, county commissions can set up local, voluntary selfheip measures for equitable distribution of heating oil and kerosene. Local civil defense agencies are equipped to provide disaster relief and assist local governments during emergencies.

State energy offices will be a main point of contact for information on fuel stockpile location, handling problems, and alternate transportation equipment.

State and local Chambers of Commerce can be very effective in local cooperative self-help measures. Some specific examples are: private donations by business, labor, and religious organizations to pay fuel bills for low-income people; fuel loan banks funded by private organizations established to make interest-free loans to pay fuel bills for the needy; and donation of millions of gallons of heating oil by a large petroleum company in the Northeast to the states for distribution to the needy through the state set as ide program.

\subsubsection{Benefits and Cost}

Self-help assistance at the local level is usually accomplished at low administrative costs with quick response time.

\section{3,9.2.4 Startup P1an}

Actions Taken

Initiate city, local, and state programs
Agency

Completion

As determined by state and local elements 


\subsubsection{Permit Emergency Supply and Transfer from Federal Stocks}

\subsubsection{Objective}

Temporary loan of federal fuel stocks, vehicles, and other equipment to civilian communities during an energy emergency to alleviate local shortages and utilization of other federal fuel supplies and equipment.

\subsubsection{Concept of Operations}

During an energy disaster, fuel stored at a federal facility could be made available to a civilian community experiencing dire shortages.

Military fuels may be loaned onty when they are not essential to the Department of Defense mission over the probable duration of the energy emergency and when fuels from other sources are not available.

Under conditions where disaster is imminent, local millitary commanders have discretionary authority to loan fuel pending the formal declaration of a disaster. However, military installations normally store only limited quantities " of fuel usable by the civilian sector. This measure is considered a "last resort," to be used only when other solutions are not avallable.

Anolher alternative can be made available by the U.S. Forest Service. In areas located near national forests, free supplies of firewood can be authorized on a temporary basis during an emergency.

Other assistance which can be made available is the use of federal (mainly military) vehicles to transport fuels and other products to an area severely impacted by an energy shortage. Consideration of this type of assistance also should be reserved for exceptional emergency situations.

\subsubsection{Benefits and Cost}

This action may provide limited relief to a civilian community during an energy emergency. 


\subsubsection{Startup Plan}

Actions Remaining

Clearly define all levels of authority in each area of

DOD,

$11 / 01 / 77$

responsibility

Publish program information

DOE

$12 / 01 / 77$

and step-by-step procedures

in Handbook

\subsubsection{Special Requirements and Documentation}

DOD Directive \#3025.1. 


\subsubsection{Assist Low-Income People in Payment of Fuel Bills}

\subsubsection{Objective}

To provide emergency assistance to low-income persons when utility cut-off or destitution is imminent. Such assistance can be in the form of money payments, payments in-kind, services; or medical or remedial care.

\subsubsection{Concept of Operations}

The current assistance program under the Social Security Act (Title IV) is limited in scope and is available only to needy families with children in the 20 participating States.

The proposed Emergency Assistantir Ar:I An!endments under the NEP would add a new segment to the Emergency Assistance Program to cover low-income individuals and families without children (as well as needy families with children), when the President has declared a natural disaster or other disastrous occurrence. The federal matching rate for this segment would be 75 percent (compared with 50 percent for the current program). This proposed legislation has recently been sent to Congress, but due to time constraints, enactment during the current session of Congress is unlikely. Therefore, assistance available for the coming winter should be considered within the context of the existing program under Title IV of the Social Security Act.

Title XX Regulations of the Social Security Act allow for payment of utility costs in emergencies. However, the amount of Title $X X$ funds is very limited. This authority should be considered as a backup, with principal reliance resting nn emergency assistance under the Title IV authority.

\subsubsection{Benefits and Cost}

Expected benefits are 1 imited in scope because of the restrictive features of the above-mentioned programs. If expanded programs are developed and additional legislation is passed, extrcms. hardship on low and tixed-income persons can be abated, and utility and fuel supply cut-offs for nonpayment of bills can be prevented. 


\subsubsection{Startup Plan}

\section{Actions Taken}

Proposed Legislation Submitted to Congress

HEW proposed legislation sent with WEEP coordination draft

to governors

Actions Remaining

Implement state and local plans

Publicize availability of

Titles IV and XX funds for emergency fuel payments

Include information on application process, beneficiary and eligibility requirements, appropriate federal/state/local contacts, and necessary documentation in the Winter Energy Emergency Handbook
Agency

HEW

DOE.

$09 / 21 / 77$

Ongoing

DOE/

HEW

Ongoing

DOE

$12 / 01 / 77$

\subsubsection{Special Requirements}

legislation.

Titles IV and XX Regulations and proposed ing and proposed legislation.

Exhibit 3.9.4 is a comparison chart of exist-

\subsubsection{Documentation}

regulations.

Social Security Act, Titles IV and XX, HEW 
EXHIBIT 3.9.

HEN ASSISTANCE TO LOW. INCOME PERSONS

(TITLE IV - SOCIAL SECURITY ACT)

\section{Requirements}

Funding -- Matching Grant

\section{State Participation}

\section{Eligibility}

Types of Payments

\section{Duration of Assistance}

Benefits

\section{Proposed Program Under Proposed Legislation}

25 percent state - 75 percent federal

Mew flexibility in program as encouragement to the 30 nonparticipating states to enter or return to the progran

Families with or without children and needy single ind viduals, including the aged and totally disabled, in all participating states in cases where the President has declared a disastrous occurrence (including severe energy crises)

M.oney payments, payments in kind, services

Ayallable for the duration of the emergency

(a) Rapid assistance in emergencies to prevent cutoffs of utilities

(b) Inclusion of all needy persons

(c) Increased federal funding 75/25 match

\section{Existing/Ongoing Program}

$50 \%$ state - $50 \%$ federal

20 states current participation

Needy families with children

Money payments, payments in kind, services

30-day $11 \mathrm{mit}$ in any 12 month period

(a) States find it difficult to meet emergencies currently

(b) Limited to families with children

(c) Limited federal funding -$50 / 50$ match

The proposed legislation would also enable states to put 'Timitations on the categories of needy families with children covered by the present ( 50 percent match) program and the types of emergencies under which families would be eligible for (50 percent match) assistance. Court decisions (under present law) preventing states from imposing such limitations have caused several states to drop the present program, and presumably deterred others from participating in the program. 


\subsubsection{Implement Special Energy Assistance for the Elderly}

\subsubsection{Objective}

the payment of fuel bills.

Supplemental assistance to the elderly for

\subsubsection{Concept of Operations}

Under the Aging Community Services Program

(Title III, 01der Americans Act), funds may be used to assist low-income elderly with payment of fuel bills. The amount of these funds is very limited. Therefore, this measure should be considered as supplemental to other assistance programs.

The administering offices for this program locally can be the area Agency on Aging, or any public or non-profit agency organization serving the needs of older people. Any American over 60 years of age is eligible to receive such funds. However, grants for this program are not made directly to individuals, but agencies or organizations servicing the elderly.

\subsubsection{Benefits and Cost}

The expected benefits from the above actions would be helping the elderly maintain a reasonable subsistence level, and meeting their financial obligations.

\subsubsection{Startup Plan}

Actions Taken

State and local plans submitted to HEW

Actions Remaining

Publish program information, eligibility requirements, authorities, contacts, etc., in Handbook
Completion Date

Annual process/date designated by HEW

HEW, state and local

Agencies on Aging

DOE

$12 / 01 / 77$

\subsubsection{Special Requirements}

None. 


\subsubsection{Documentation}

for Title III funding.

Title III, 01der Americans Act; HEW Regulations 


\subsubsection{CSA Crisis Intervention}

\subsubsection{Objective}

Use Community Service Administration funds to assist low-income people in paying for high fuel bills.

\subsubsection{Concept of Operations}

The Community Service Administration (CSA), administers a crisis intervention program designed to help low-income people meet the rising costs of fuel and to prevent fuel supply stoppage.

This year CSA has had responsibility for administering the following two programs through its local Community Action Agencies (CAA):

(1) An ongoing crisis intervention program which makes grants and loans to low-income persons to purchase fuel; mediates with utility companies to prevent termination of services; maintains emergency supplies of fuel, warm clothing, and blankets; and runs fuel voucher programs.

(2) The Special Crisis Intervention Program (SCIP), a fuel payment assistance program created by Congress through a $\$ 200 \mathrm{million}$ supplemental appropriation to CSA, was a one-time emergency program which authorized a maximum of $\$ 250$ payments to eligible lowincome people to help them pay unpaid fuel bills from last winter. This program expired September 30, 1977. Any unobligated monies reverted to CSA's weatherization program.

On October 28, the Senate Appropriations Committee began consideration of a supplemental CSA appropriation of $\$ 200$ million for grants to low-income households to relieve the burden of high fuel costs this winter during energy emergencies. This emergency fuel assistance program is an interim measure as an alternative to the HEW proposed legislation on emergency assistance which is unlikely to pass in time to be of help this winter.

This appropriation bill was passed by the Senate on November 1 . The House of Representatives did not consider this program, therefore, Senate-House conferees will take up consideration of this measure on November 2.

On October 27, Office of Management and Budget Acting Director James McIntyre, in a letter to Senator Magnuson, Cha irman of the Senate Appropriations Subcommittee on Health, Education and Welfare, endorsed this special assistance program with certain caveats. (Exhibit 3.9) 


\subsubsection{Benefits and Cost}

Benefits from this program are relief to lowincome people from increasing fuel bill costs during very cold weather.

Based upon present funding without a supplemiental appropriation, it is estimated that fuel bill allotments cannot exceed about $\$ 16$ million (30 percent of $\$ 65$ million less administrative costs).

\subsubsection{Startup Plan}

Actions Remaining

Recommended to Congress renewed legislation for SCIP Program and improvements in previous program

Administration endorsement of new CSA Emergency Assistance

Program

Passed Senate, Referred to Huuse-Senate Conference

Actions Remaining

Include program information, eligibility, procedures, etc., in Handbook

$\begin{array}{cc}\frac{\text { Agency }}{\text { CSA }} & \frac{\text { Completion Date }}{09 / 20 / 77} \\ \text { OMB } & \ldots \\ & 10 / 27 / 77\end{array}$

$11 / 1 / 77$

DOE $12 / 01 / 77$

\subsubsection{Special Requirements}

Congressiund action to appropriate additional crisis intervention funds so programs can be implemented in timie to be useful this winter.

\subsubsection{Documentation}

1964, as emmended.

Section 222 A12, Economic opportunity Act of

Senator Magnuson

OMB Acting Director McIntyre's letter to 


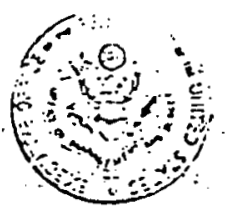

\section{EXECUTIVE OFFICE OF THE PRESIDENT}

OFFIICE OF MANAGEMENT AND BUDGET

WASHINGTON. D.C. 20503

October 27,1977

Honorable Warren G. Magnuson

Chairman, Subcomittee on

Labor and Health, Eaucation

and velfare

Senate Committee on Appropriations

Room 1108 Dirkson Building

Washington, D.C. 20515

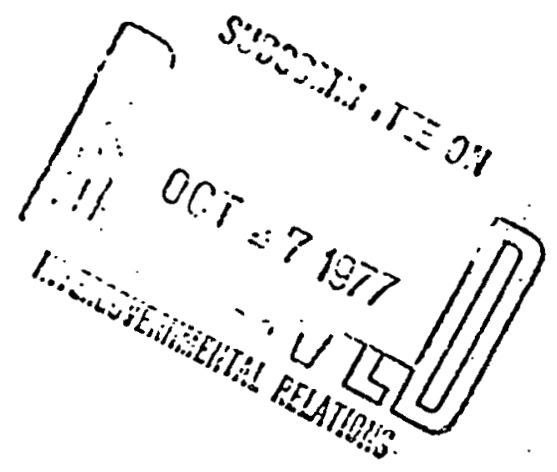

Dear Senator Magnuson:

I am writing to you to express my concern regarding the ability of the feceral Government to act quickly and effectively in response to the emergency energy needs that arise this coming winter.

We understand that the Senate Comnittee on Appropriations has under consideration the addition of $\$ 200 \mathrm{milli}$ ion to the Supplemental Appropriations bill for fiscal year 1978 to aid those seriously affected by potential energy energencies this winter, The Administration strongly supportsefforts to assure that needy frnerican householas do not suffer severe aistress from extraordinary energy costs: and we believe that the proposal under consjderation by the committee can responsibly provide that assurance if that proposal contains certain essential provisions.

Iast winter's severe: weather pointed up the shortconings 0 f. the present Emergency Assistance program of the. Department of Health, Education, and Welfare and caused. the Congress to add special funding for the: Community Services Adninistration to aid those seriously affected. unfortunately, the special assistance tended not to be targeted narrowly enough on. those areas most in need since it was distributed as a Formula grant, was àiverted into activities that were not. of an imeaiate crisis character (such as weatherization), and often was available to pay fuel bills well after the height of the emiergency had passed. 
The Administration's recent Emergency fissistance proposal, transmitted to the Congress in September, would correct the present law's deficiencies.

Because the Administration's bill has not yet progressed in the Congress, and other legislation is not likely to be enacted before possible energy emergencies may occur, we believe an interim contingency program is advisable.

Uncier the CSA authority previously used, contingency funding under the conditions noted below would proviae a stop-gap basis for aiding people severely affected financially by an energy. emergency:

-- No funds should be used for weatherization activitico thest services can be provided by existing programs and funds.

-- The use of thesc funds should be contingent on. the actual declaration of emergency by some authority, i.e., the Director of CSA aftex consuitation with the Secretary of Energy. Funds should not simply be aistributed to states and localities for whatever use they see fit: The monei should instead be carefully targeted on those seriously affected by an energy emergency if one occurs.

Funds should only be expended as necessary, and should revert to the Treasury if not used.

The finnis provided: chould be available for use in the ndministration's proposed tiriergency. Assistance program. when and if it is enacted.

I. the amount to be made available for assistance to householcs to meet energy emergencies is obligated according to the above conditions, I believe it will exiectively meet any energy emergencies. which may occur this winter.

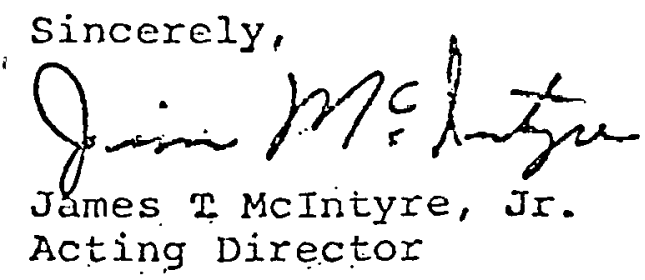

cc: rionorable Edmund Muskie 


\subsubsection{Issue Emergency Food Stamps to Supplement Needs}

\section{During an Energy Emergency}

\subsubsection{Objective}

Use food stamps issued during an energy emergency to mitigate economic impacts of such an emergency on low-income people.

\subsubsection{Concept of Operations}

During last winter's energy crisis, the Food and Nutrition Service of the U.S. Department of Agriculture permitted free food stamps to be issued to areas which met USDA's criteria for an emergency situation.

The regular food stamp program can be converted to an emergency plan without a Presidential declaration of a disaster. When USDA approves a state welfare agency's request for declaration of an emergency, the emergency program can be established to issue free food stamps. There is no requirement for repayment at a later date for stamps issued under such a plan.

In times of non-emergency, the regular food stamp program has an indirect compensation for low-income persons to meet high fuel costs. Fuel costs can be included in shelter cost deductions to determine the applicant's net income. As the net income becomes lower, the food stamp allotment and purchasing power increases.

In addition, this program can be used by qualifying workers temporarily unemployed due to plant shutdowns resulting from energy shortaces.

\subsubsection{Benefits and Cost}

Additional food stamps issued during an energy emergency will help to mitigate the economic impact of the emergency on low-income people. 


\subsubsection{Startup P1an}

Actions Taken

Agency

Completion Date

None

Actions Remaining

Request declaration of

State Welfare Office

At time of emergency

State Welfare Office

USDA

To be determined by

Authorize Emergency

Food Stamp Program

DOF USDA

Publish program information. procedures, authorities, eligibility, etc., in

Handbook

\subsubsection{Special Requirements and Documentation} USDA/Food and Nutrition Services Program Proce-

dures. 


\subsubsection{Expedite Unemployment Compensation Claims Resulting from} Layoffs due to Energy Shortages

\subsubsection{Objective}

related unemployment.

Mitigate loss of income due to energy shortage-

\subsubsection{Concept of Operations}

Extreme energy shortages often result in mass industrial layoffs, imposing undue economic hardship on the affected employees. In order to assure continued income flow to such individuals, Unemployment Insurance offices can take steps to expedite the resultant claims. For example, local unemployment offices have been given permission in the past to accept and process claims at industrial plant locations when layoffs have occurred.

\subsubsection{Benefits and Cost}

Affected persons can continue to meet their financial commitments and maintain a reasonable subsistence level. Such actions help to stop the economic impact by minimizing the spillover into other segments of the commercial sector. In short, it assists in the prevention of an economic chain reaction into other segments of the community.

\subsubsection{Startup Plan}

Actions Remaining

Prepare standby waivers and temporary authorizations to expedite payments

Include program information eligilibility requirements contacts, authority, etc. in Handbook
Agency

$\mathrm{DOL}$

DOE
Completion Date

To be determined by DOL

December 1

\subsubsection{Special Requirements and Documentation}

None 


\subsubsection{Set Up Short-Term Public Service Employment}

\subsubsection{Objective}

Provide temporary jobs to people unemployed because of an energy shortage.

\subsubsection{Concept of Operations}

Under the Comprehensive Employment and Training Act (CETA) administered by the Department of Labor (DOL), CETA funds can be directed to alleviate unemployment in areas where industrial plants have been forced to close due to energy shortages.

Under this prograll, short-term public service employment can be provided by state and local governments for jobs that are normally performed by those agencies. Examples are municipal public works and state highwdy departments. However, CETA eligibility criteria must be met.

\section{Because of previous difficulties cncountered} in trying to accurately report energy-related unemployment statistics in a timely manner the Bureau of Labor statistics has revamped its umemployment data collection effort. This winter, BLS proposes to have weekly rather than monthly reports available that reflect the actual employment picture and pinpoints impacted areas. Such timely information would enable the Secretary of Labor to quickly determine the need to use the CETA program in any part of the colintry as an emergency measure.

\subsubsection{Benefits and Cost}

Such action helps to mitigate the economic hardship caused by unemployment, thereby cutting down on the financial assistance required under other local programs. \$280 million of discretionary funds are available through the end of the year.

\subsubsection{Startup Plan}

Actions Remaining

BLS Report to Secretary
Agency

BLS
Completion Date

As determined hy DOL 
Actions Remaining (Con't)

Activate ETA (DOL) Emergency

Plan to expedite use of

CETA for emergency situations

Include program information,

eligibility authorities, etc.

in Handbook
Agency

DOL

Prime

Sponsors

DOE
Completion Date

As determined by DOL

December 1

\subsubsection{Special Requirements}

BLS Unemployment Statistics.

for emergency purposes.

Labor Secretary's decision to use CETA program

3.9.9.6 Documentation

CETA, TitTe II 


\subsubsection{Encourage Moratoria on Utility Service Cut-Offs and Non-Delivery fo Heating Fuels due to Lack of Cash}

\subsubsection{Objective}

To assure that no one will suffer from lack of heat during a very cold winter because of inability to pay utility or fuel bills.

\subsubsection{Concept of Operations}

Comments received by the Winter Energy Emergency Planning (WEEP) Task Force on the coordination draft of this planning guide identified problems encountered last winter usinq the moratorium approach. Fur example, in some states the ban did not differentiate between class of user. by income level, resulting in the accumulation of extremely large unpaid utility bills by many with the ability to pay. Because of this problem, certain states are considering not imposing the moratoria for this coming winter.

The Department of Energy (DOE) is well aware that small. fuel dealers may have difficulty financing no cut-off for an extended period of time. In fact, the problem of cash flow for small fuel dealers confronted with large unpaid accounts is of such serious and important consequence, it will be addressed as a separate issue.

DOE has already published a notice in the Federal. Register (0ct. 13) announcing the formation of an ad hoc subcommittee to the DOE Fuel 0il Marketing Advisory Committee which will hold meetings in several locations throughout the country over the next month and a half. The subcommittee's objective is to conduct a study and make recommendations to the parent committee concerning the competitive viability of the small heating oil marketers.

Nevertheless, the serious impact of high utility. and fuel bills on low-income consumers is so important no cut-off is still considered a valuable and important assistance measure. Even though this measure comes solely within the purview of state public utility commissions, utllity companies with voluntary plans and fuel oil marketers, it will still be included in the Handbook as a suggested method of alleviating an extreme situation.

Among the suggested alternatives which can be implemented by utility companies as well as fuel oil dealers are:

- institution of deferred payment plans

- Negotiation of extension of service agreements 
- Establishment of an informal review process to discuss and resolve issues before service is terminated

- Agreement not to terminate service during a customer's serious illness.

Certain provisions in the National Energy Act dealing with utility termination procedures and special lifeline rates for the elderly will be considered by the Senate-House Conferees currently working on the compromise bill.

\subsubsection{Benefits and Cost}

Implementation of this measure would assure that low-income and indigent people would not suffer hazardous health conditions during the winter months because they could not pay their heating bills.

\subsubsection{Startup Plan}

Actions Remaining

Encourage state PUC's to initiate action

Issue mandatory moratorium plans or encourage voluntary adoption

of plans

Establish voluntary prọgrams
Agency

DOE

State PUC's

Utility

Companies

Completion Date

\subsubsection{Special Requirements and Documentation}

PUC orders 


\subsubsection{Provide Small Business Assistance for Energy Related Emergencies}

\subsubsection{Objective}

Provide financial assistance to small businesses which are in difficulty due to energy shortages.

\subsubsection{Concept of Operations}

A small business enterprise which can prove "economic injury" due to an energy shortage or energy-related natural shortage can apply to the Small Business Administration (SBA) for renegotiation of its loan, obtain a new loan or delay payment un a luan for a period of months through agreement with SBA.

Under the program an eligible small business firm which has been seriously affected by a shortage of fuel, electrical energy or energy producing resources, or by a shortage of raw or processed materials resulting from such shortages may use the SBA loan to refinance short-term debts, convert its operation to a different fuel source, or cover obligations by using the money for working capital.

For this type of financial assistance the SBA operates under the provisions of Section $7 B 8$ of the Small Business Act and the Emergency Energy Shortage Economic Injury Loan or EES Crisis Loans. Maturity on loans can range up to 30 years with no dollar limit.

\subsubsection{Benefits and Cost}

This measure mitigates the economic impact on a small commerical firm and, in many cases, prevents the firm from going out of business because of severe energy impacts. It may enable the firm to continue its services without increasing prices to consumers or closing down.

\subsubsection{Startup Plan}

Actions Remaining

Implement at time of severe energy shortage

Include program information in Handbook
SBA

Determined by SBA

DOE

December 1 
3.9.11.5 Special Requirements

None

3.9.11.6 Documentation

Section 7(b)(8), Small Business Act, PL 93-386 